\title{
Schistosomiasis with a Focus on Africa
}

\author{
Oyime Poise Aula ${ }^{1,2, * \mathbb{D}}$, Donald P. McManus ${ }^{1} \mathbb{D}$, Malcolm K. Jones ${ }^{3}$ and Catherine A. Gordon ${ }^{1, * \mathbb{D}}$ \\ 1 School of Public Health, Faculty of Medicine, University of Queensland, Brisbane 4006, Australia; \\ Don.McManus@qimrberghofer.edu.au \\ 2 Molecular Parasitology Laboratory, QIMR Berghofer Medical Research Institute, Brisbane 4006, Australia \\ 3 School of Veterinary Sciences, University of Queensland, Gatton 4343, Australia; m.jones@uq.edu.au \\ * Correspondence: Oyime.Aula@qimrberghofer.edu.au (O.P.A.); \\ Catherine.Gordon@qimrberghofer.edu.au (C.A.G.)
}

Citation: Aula, O.P.; McManus, D.P.; Jones, M.K.; Gordon, C.A.

Schistosomiasis with a Focus on

Africa. Trop. Med. Infect. Dis. 2021, 6 , 109. https://doi.org/10.3390/

tropicalmed6030109

Academic Editors:

Constantinos Tsioutis and

Spyridon Karageorgos

Received: 13 May 2021

Accepted: 4 June 2021

Published: 22 June 2021

Publisher's Note: MDPI stays neutral with regard to jurisdictional claims in published maps and institutional affiliations.

Copyright: (c) 2021 by the authors. Licensee MDPI, Basel, Switzerland. This article is an open access article distributed under the terms and conditions of the Creative Commons Attribution (CC BY) license (https:// creativecommons.org/licenses/by/ $4.0 /)$.

\begin{abstract}
Schistosomiasis is a common neglected tropical disease of impoverished people and livestock in many developing countries in tropical Africa, the Middle East, Asia, and Latin America. Substantial progress has been made in controlling schistosomiasis in some African countries, but the disease still prevails in most parts of sub-Saharan Africa with an estimated 800 million people at risk of infection. Current control strategies rely primarily on treatment with praziquantel, as no vaccine is available; however, treatment alone does not prevent reinfection. There has been emphasis on the use of integrated approaches in the control and elimination of the disease in recent years with the development of health infrastructure and health education. However, there is a need to evaluate the present status of African schistosomiasis, primarily caused by Schistosoma mansoni and S. haematobium, and the factors affecting the disease as the basis for developing more effective control and elimination strategies in the future. This review provides an historical perspective of schistosomiasis in Africa and discusses the current status of control efforts in those countries where the disease is endemic.
\end{abstract}

Keywords: schistosomiasis; Schistosoma haematobium; Schistosoma mansoni; sub-Saharan Africa; Africa

\section{Introduction}

Schistosomiasis is a snail borne, fresh water-transmitted neglected tropical disease (NTD) of poverty in many developing countries in tropical and sub-tropical Africa, the Middle East, Asia, and Latin America [1-3] (Table 1). The disease is generally endemic in low-income rural communities without access to potable water, proper sanitation, and adequate healthcare facilities. Sub-Saharan Africa (SSA) constitutes about $13 \%$ of the world's population but accounts for up to $90 \%$ of cases with an estimated 280,000 deaths due to schistosomiasis annually [2]. The two major species infecting humans in subSaharan Africa are Schistosoma haematobium, which causes urogenital schistosomiasis and S. mansoni, the cause of intestinal schistosomiasis. S. intercalatum and S. guineensis also cause intestinal schistosomiasis but are less prevalent (Table 1) [4]. Similarly, the main schistosome species infecting animals are S. mattheei, S. bovis and S. currassoni (Table 1). In recent years, there have been cases of locally acquired urinary schistosomiasis cases caused by $S$. haematobium reported in Corsica, France where it had previously not been endemic, likely imported by individuals infected in West Africa [5,6]. There is also increasing evidence of hybridization events between human and animal schistosome species, leading to new zoonotic infections [7-9]. 
Table 1. African schistosome species and their geographical distribution.

\begin{tabular}{|c|c|c|c|c|c|c|}
\hline & Species & $\begin{array}{c}\text { Intermediate } \\
\text { Host }\end{array}$ & Definitive Hosts & Site of Infection & $\begin{array}{c}\text { Geographical } \\
\text { Distribution }\end{array}$ & References \\
\hline \multirow{2}{*}{$\begin{array}{c}\text { Intestinal } \\
\text { schistosomiasis }\end{array}$} & S. mansoni & Biomphalari spp. & Humans, rodents & $\begin{array}{c}\text { Intestinal } \\
\text { mesenteric veins }\end{array}$ & $\begin{array}{l}\text { Sub-Saharan Africa, } \\
\text { Madagascar, the } \\
\text { Middle East, } \\
\text { the Caribbean, } \\
\text { South America }\end{array}$ & {$[1,10]$} \\
\hline & $\begin{array}{l}\text { S. intercalatum } \\
\text { and S. guineensis }\end{array}$ & Bulinus spp. & $\begin{array}{c}\text { Humans, } \\
\text { non-human } \\
\text { primates } \\
\text { (excluding apes) }\end{array}$ & $\begin{array}{c}\text { Intestinal } \\
\text { mesenteric veins }\end{array}$ & $\begin{array}{l}\text { Central Africa, West } \\
\text { Africa, Madagascar }\end{array}$ & {$[1,10,11]$} \\
\hline $\begin{array}{l}\text { Urogenital } \\
\text { schistosomiasis }\end{array}$ & S. haematobium & Bulinus spp. & $\begin{array}{c}\text { Humans, } \\
\text { non-human } \\
\text { primates } \\
\text { (excluding apes) }\end{array}$ & Urogenital veins & $\begin{array}{l}\text { Sub-Saharan Africa, } \\
\text { the Middle East, } \\
\text { Corsica (France) }\end{array}$ & {$[1,10]$} \\
\hline \multirow{3}{*}{$\underset{\begin{array}{c}\text { Animal } \\
\text { intestinal } \\
\text { schistosomiasis }\end{array}}{\text {. }}$} & S. mattheei & Bulinus spp. & $\begin{array}{l}\text { Cattle, sheep, } \\
\text { goats }\end{array}$ & $\begin{array}{c}\text { Intestinal } \\
\text { mesenteric veins }\end{array}$ & $\begin{array}{c}\text { Southeastern and } \\
\text { Central Africa }\end{array}$ & [12-15] \\
\hline & S. curassoni & Bulinus spp. & $\begin{array}{l}\text { Cattle, sheep, } \\
\text { goats }\end{array}$ & $\begin{array}{c}\text { Intestinal } \\
\text { mesenteric veins }\end{array}$ & West Africa & [12-15] \\
\hline & S. bovis & Bulinus spp. & $\begin{array}{l}\text { Cattle, goats, } \\
\text { sheep, horses, } \\
\text { camels, pigs }\end{array}$ & $\begin{array}{c}\text { Intestinal } \\
\text { mesenteric veins }\end{array}$ & $\begin{array}{l}\text { North, East, West } \\
\text { and Central Africa, } \\
\text { the Middle East and } \\
\text { Mediterranean } \\
\text { (Europe) region }\end{array}$ & [12-15] \\
\hline
\end{tabular}

Schistosomiasis control programs in Africa focus predominantly on community-based preventive chemotherapy (PC), focusing on mass drug administration (MDA) with praziquantel (PZQ), a broad spectrum anthelminthic, to reduce morbidity. Every year PZQ is donated to endemic countries in Africa to treat millions of school-aged children (SAC) $[16,17]$. Treatment compliance is challenging, especially among individuals in low socioeconomic areas due to fear of adverse effects, apparent absence of disease symptoms, and even when symptoms occur, they are often met with stigmatisation $[18,19]$ or seen as a normal sign of puberty $[20,21]$ not requiring treatment. There have been increased efforts aimed at eliminating schistosomiasis in the past decade with the World Health Organization (WHO) setting 2030 as the goal for transmission interruption in endemic African countries [22]. Government agencies from many countries have prioritised the control of NTDs by exploiting breakpoints in their lifecycles, such as the implementation of snail control and through improvements in sanitation and access to safe, clean water [23,24]. However, in sub-Saharan Africa, PC is still the major intervention practiced. As PZQ is ineffective against migrating schistosomula, if these larvae are present in an individual, treatment may not prevent their maturation to adults and resultant patency. Rapid re-infection following treatment with PZQ is also common [25-27].

$\mathrm{SAC}$ are the main targets for control as they are considered to be at the highest risk of infection, being more likely to participate in daily activities including fishing, rice farming and swimming, that put them at greater risk of infection compared with other age groups. Protective immune responses against schistosomes develop slowly, with children from schistosomiasis-endemic areas being generally susceptible to reinfection after treatment for schistosome infection, whereas adults are usually protected [10]. This observation can explain the characteristic age-prevalence and age-intensity curves observed in schistosomiasis-endemic areas in Africa [11,28,29].

\section{Pathogenesis}

\subsection{Life Cycle of Schistosoma sp.}

Schistosomes have a complex life cycle involving both intermediate gastropod hosts and a definitive mammalian host (Figure 1). Unlike other trematode species, Schistosoma spp. are dioecious (separate male and female worms) which undergo sexual reproduction in the mammalian definitive host. Schistosome eggs are produced and excreted into the environement via the faeces (S. mansoni) or urine (S. haematobium). Miracidia are released 
when the eggs come in contact with water and infect the snail host. There, miracidia develops into mother sporocysts and undergo asexual reproduction to produce daughter sporocysts which produce cecariae. Infected snails shed cercariae into the water and upon locating a suitable definitive host, penetrate the skin, transform into schistosomula and migrate through the circulatory system to the lungs, heart and liver where they mature into adult worms (Figure 1). The adult worms then exit the liver and pair up to mate in the mesenteric vessels of the bowel (S. mansoni, S. intercalatum) or bladder (S. haematobium).

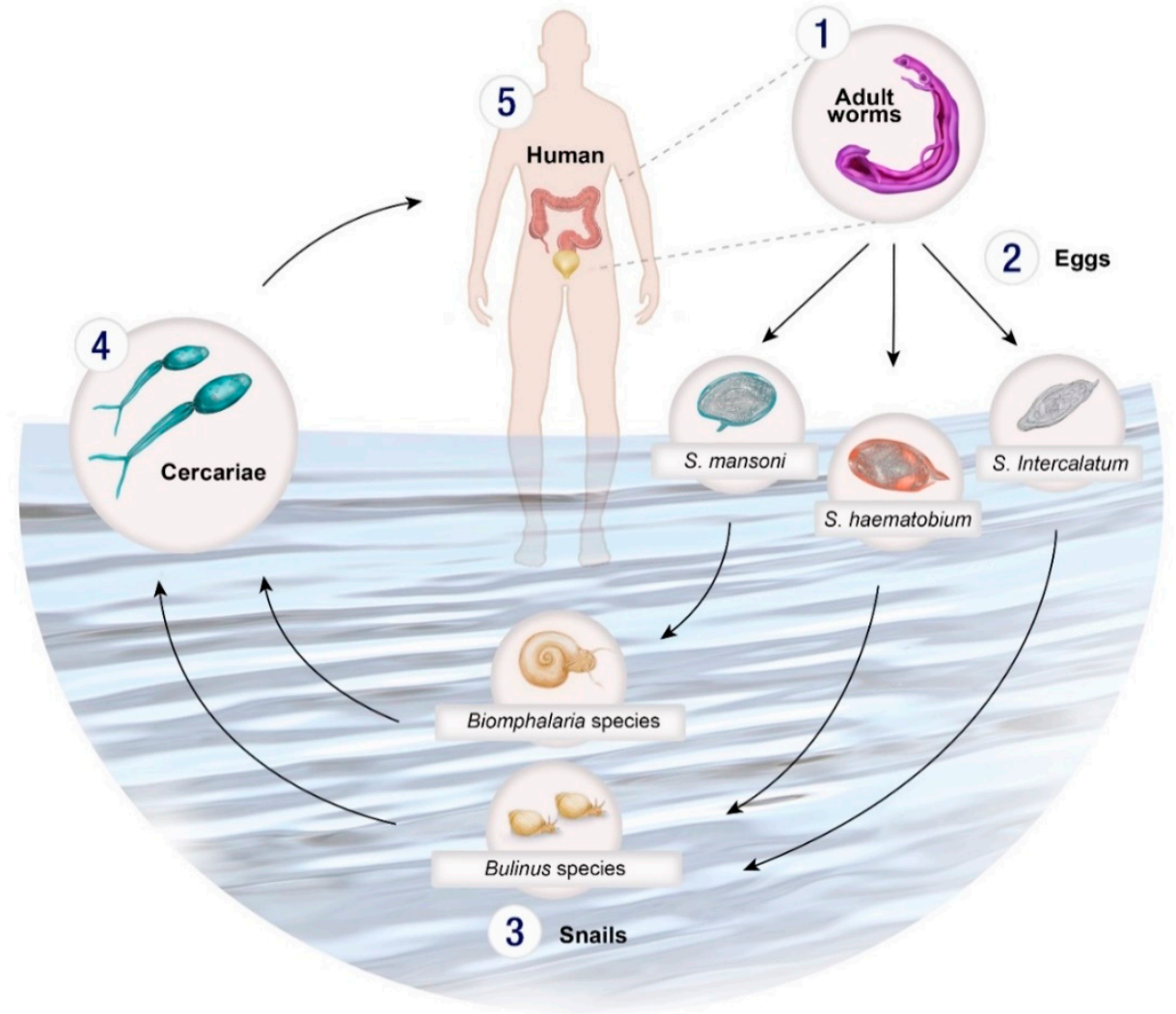

Figure 1. Life cycle of Schistosoma spp. (1) Male and female adult worms reproduce sexually in the venous system of the bladder (S. haematobium) or the bowel (S. mansoni, S. intercalatum, S. guineensis) producing eggs which are excreted in urine or via faeces, or are retained in body tissues, such as the liver. (2) The eggs hatch upon contact with water releasing miracidia which then penetrate a specific intermediate molluscan host. (3) Within the snail host, the miracidia develop into sporocysts and asexually reproduce daughter sporocysts which in turn produce cercariae. (4) The cercariae emerge from the snail and directly penetrate the skin of the (5) human host and transform into schistosomula. The schistosomula migrate via the circulatory system to the lungs and then the heart before arriving in the liver where they mature. Once mature the adult worms exit the liver and pair up to mate in the mesenteric vessels of the bowel bowel (S. mansoni, S. intercalatum, S. guineensis) or bladder (S. haematobium).

A proportion of the eggs are carried by the bloodstream to other areas of the body where they can become lodged in tissues, and trigger an inflammatory response, causing acute or chronic disease. (Figure 1). Schistosomes have an average life span of 3-10 years but can live up to 40 years in their human hosts in permanent copulation [30,31].

The control and elimination of schistosomiasis requires interruption of a complex pathway of transmission governed by the interplay of humans, intermediate host snails and human-water contact patterns. The snail hosts are crucial for determining the range of schistosomiasis and are responsible for the focal nature of the disease (i.e., highly variable infection prevalence and intensity even within a small area such as from one village to 
another). Two genera of snails (Bulinus and Biomphalaria) are responsible for the distribution of schistosomes in Africa (Table 1). These molluscs can be an important focus of control efforts involving environmental modification (e.g., digging water drainage ditches or tunnels to flood and bury the snail habitats to disrupt snail habitats), or through the use of chemicals, such as niclosamide [32,33]. Concerning, however, are the detrimental impacts that such chemicals can have on the environment including the general pollution they cause and being toxic to larger animals such as fish [34,35].

\subsection{Clinical Presentation of Schistosomiasis in Africa}

Schistosome infection has three distinct disease phases beginning with an initial dermatitis reaction following skin penetration by the cercariae resulting in an allergic inflammatory maculopapular lesion [36]. The infection may then proceed to a symptomatic acute schistosomiasis stage also known as Katayama fever or Katayama syndrome. Acute schistosomiasis is rarely reported in individuals living in areas endemic for S. mansoni or S. haematobium. One possible explanation for this being that in-utero sensitisation might decrease the severity of common symptoms of Katayama syndrome in chronically exposed individuals resulting in lowered immune responsiveness to schistosome antigens in infants born to infected mothers; it may also be equally likely that cases from endemic areas are simply unrecognised or under-reported [36,37]. The most common symptoms of acute schistosomiasis include prolonged fever, weakness, vomiting, nausea, diarrhoea, malaise and rapid weight loss [4,38]. The third and final disease stage, chronic schistosomiasis, occurs when eggs are deposited in various body tissues, commonly affecting the liver, bladder and urogenital system, and less commonly in the central nervous system $[4,39]$. Adult worms can avoid detection by the immune system by camouflaging their outer layer with host antigens and tegmental shedding and are able to reside for long periods in their hosts [40]. In contrast, schistosome eggs are fully exposed to the immune system, and this results in the formation of granulomatous and fibrotic lesions around the eggs in various tissues resulting in necrosis, ulceration and bleeding that can have long-term detrimental effects $[4,38,41,42]$. Chronic schistosomiasis is associated with hepatosplenomegaly, portal fibrosis and, in the case of S. haematobium, haematuria (blood in urine), ureter fibrosis, and squamous cell carcinoma of the urinary bladder [4].

S. mansoni is the leading cause of intestinal schistosomiasis in Africa (Table 1). Around $50 \%$ of eggs deposited by adult worms are retained in the liver, causing chronic disease [43]. Pathogenesis due to $S$. intercalatum is less severe than S. mansoni and S. haematobium and most infected patients, particularly children, do not show symptoms of the disease [44].

\subsubsection{Female Genital Schistosomiasis}

Female genital schistosomiasis (FGS) is characterised by the presence of S. haematobium eggs in the vagina and cervix and affects up to 20 million women in sub-Saharan Africa and the Middle East $[45,46]$. The eggs penetrate the urogenital system, causing uterine enlargement, menstrual disorders, cervicitis and infertility [47]. Schistosomiasis in pregnant women presents with symptoms ranging from anaemia during pregnancy to newborns with low birth weight, and increased infant and maternal mortality rates [48-51]. Urogenital schistosomiasis has also been linked with increased risk of HIV infection in women resulting from the production of genital mucosal lesions surrounding the eggs $[52,53]$. The immune response caused by S. haematobium infection leads to chronic inflammatory granulomatous lesions, genital epithelial bleeding and sandy patches in the cervix and vagina that, if left untreated, can become an easy entry point for the HIV virus, as well as leading to infertility [30,52,54-57]. Concurrent infection with HIV and S. haematobium leads to increased disease pathology while HIV infection may lead to an increased chance of contracting schistosomiasis [52,58,59]. Schistosomiasis has also been suspected of increasing disease progression and death in HIV patients by increasing the HIV RNA load in the blood plasma [60,61]. More than 70\% of HIV infections worldwide occur in sub-Saharan Africa and thus HIV remains a major health challenge in Africa and an important confounding 
factor for schistosome infection. Diagnosis of FGS can be challenging due to different transformation stages of the $S$. haematobium parasite and immune response in the affected tissues. In cases where the infected patient is asymptomatic, the disease may be mistaken for sexually transmitted diseases (STDs) or cervical cancer [18,46,62]. Stigma against STDs can lead to misdiagnosis, or reluctance of young women to present to a doctor when experiencing clinical symptoms of FGS.

\subsubsection{Primary and Secondary Infertility in S. haematobium Infections}

Infertility is the inability to become pregnant after regular and unprotected sexual intercourse for more than one year [63]. It can be diagnosed as either primary-where the woman has never conceived, or secondary-when the woman has experienced previous labour. Suspected cases of infertility resulting from S. haematobium infection in the genital tracts have been widely reported in Africa [64-70]. While the presence of an adult worm infection in the urogenital system is generally asymptomatic, the deposition of S. haematobium eggs along the urogenital tract, including the cervix and vagina, trigger a hypersensitive immune response, causing scarring and fibrosis in the genital tract, ovaries and fallopian tubes. The eggs may appear as papillary white lesions $[64,65]$, causing thickening, nodular lesions and adhesions which eventually lead to obstruction and blockage of the fallopian tubes. The resulting fibrosis and blockage is suspected to lead to infertility. A case study in Nigeria reported the inability of a woman to get pregnant with her second child despite having a regular menstrual cycle; tuboplasty (surgery undertaken to restore the functionality and integrity of the fallopian tubes) revealed lesions and blockage of the patient's fallopian tubes due to the presence of S. haematobium eggs [65]. Urogenital schistosomiasis has also been linked to ectopic pregnancies as a result of blockage of the fallopian tubes $[66,67]$. Patients can recover with administration of PZQ if the infection is treated sufficiently early $[65,66]$.

\subsubsection{Male Genital Schistosomiasis}

Male genital schistosomiasis (MGS) was first reported in 1911 [71] and is described as the presence of schistosome (S. haematobium) eggs in the male genital organs and fluids. The awareness and severity of this disease especially in endemic areas is often overlooked and underreported as it can be misdiagnosed as a sexually transmitted infection (STI) $[59,72,73]$. Symptoms of this disease include painful urination, painful ejaculation, irregular ejaculations, hermatospermia, prostatitis, epididymitis (inflammation of the epididymitis at the back of the testicles), which could mimic tuberculosis and associated funiculitis, erectile dysfunction, enlarged genital organs and infertility [59,74-76].

\subsubsection{Bladder Cancer in S. haematobium Infections}

Globally, 275,000 people are diagnosed with bladder cancer annually and 108,000 people die of the disease. Bladder cancer caused by translational cell carcinoma (TCC) occurs in industrialised and developing countries not endemic for urogenital schistosomiasis, while bladder cancer caused by squamous cell carcinoma (SCC) is a long-term sequela of chronic infection and occurs in many parts of Africa plagued with urogenital schistosomiasis [77,78]. Bladder cancer is one of the foremost serious complications of chronic S. haematobium infection and it is estimated that the schistosome-associated bladder cancer incidence is 3-4 cases per 100,000 infections [79].

TCC arises from the transitional epithelium lining of the bladder and presents in its early stage as a painless haematuria. In contrast, a squamous hyperplasia (usually not present in a normal urothelium which is a highly specialized epithelium lining the lower urinary tract) gives rise to SCC due to injuries caused by the immunological responses to deposited eggs in the bladder [80]. This is followed by painful haematuria, chronic inflammation and necroturia [80]. SCC often presents with symptoms only at a late stage and can be challenging to treat by surgery or with chemotherapy. 
A study in Egypt reported that $82 \%$ of patients with SCC had S. haematobium eggs lodged in their bladder wall and infected individuals had the tendency to develop cancer at a younger age than uninfected individuals [81]. Kitinya et al. [82] reported that of 172 individuals with bladder cancer in Egypt over a nine year period (1971-1980), 72\% were SCC cases. Similarly, a study in Northern Tanzania reported $46 \%$ of SCC patients had S. haematobium eggs in the tumour tissues [82]. Another study from Angola, situated in the western part of Western Africa, reported a $>70 \%$ (215/300) S. haematobium prevalence with 3 of the infected patients having calcified bladders and one SCC case was recorded [83]. A decrease in the prevalence of urogenital schistosomiasis in Egypt has seen a decline in the SCC and an increase in the median age of infected individuals with bladder cancer [84].

The mechanisms associated with S. haematobium and the development of SCC are largely unknown although the carcinogenic process appears to be closely related to tissue inflammation [3]. Botelho et al. [85] described the relationship between S. haematobium and cancer by exposing normal epithelial cells (Chinese Hamster Ovary (CHO) cells) in culture with S. haematobium total antigen and observed increased cell proliferation, decreased apoptosis, migration, invasion and tumourigenesis $[85,86]$. This suggested that S. haematobium has the ability to induce the formation of cancer-like cells [85]. Furthermore, S. haematobium exposed cells injected into mice with no immune system resulted in the development of tumours similar to those found in bladder cancer [87].

\subsection{Treatment and Control}

Preventive chemotherapy (PC) through MDA with PZQ is the cornerstone of the treatment and control of schistosomiasis in endemic regions of Africa. PZQ has been proven a safe and effective oral drug active against adult worms of all Schistosoma species [88,89], although its mechanism of action is still not fully understood. However, it cannot be used for chemoprophylaxis due to its short half-life, and it is ineffective against migrating schistosomula [90]. Corticosteroids, in addition to PZQ, are effective as an adjuvant when patients present with Katayama syndrome, usually within two months of exposure to cercariae $[37,91]$ to suppress immunological reactions and prevent acute disease. Other drugs that proved effective for the treatment of schistosomiasis include oxamniquine for S. mansoni, and metrifonate for S. haematobium $[4,38]$ but these are either no longer readily available or have been withdrawn due to unacceptable toxicity. Co-infections of Schistosoma spp. and soil-transmitted helminths (STH) are common in many endemic areas in Africa, and as such, combination PC with both PZQ and albendazole is recommended by WHO [92] particularly for SAC and other high risk groups.

PZQ is given to SAC between the ages of 5 and 15 years who have the highest infection rates and are more readily reached through school programs. PC is usually carried out by firstly assessing the prevalence of the disease which determines the frequency of treatment in that area [93]. For example, areas showing disease prevalence with $50 \%$ or more usually should receive a single annual treatment while areas with $10 \%$ prevalence will receive triennial treatment [93]. As of 2019, 57.1\% (61.8 million) SAC who require treatment have received PZQ [94].

Re-infection remains a major challenge to control efforts in Africa due to a number of factors including: high levels of infection prevalence and intensity, poor or non-compliance of PZQ treatment and low coverage, recontacting contaminated water as a result of daily activities and seasonal factors. Hence, a multifaceted intervention approach will be needed to move from wide-spread control to elimination including: snail control; treatment; effective risk mapping and epidemiological surveillance; accurate diagnostics; improved access to clean water, sanitation and hygiene (WASH); and public health education to bring about behavioural changes to prevent infection and reinfection [95-99]. These integrated approaches, together with the development and deployment of future anti-schistosome vaccines effective in humans (albeit no schistosomiasis vaccine has yet been accepted for public use) will contribute greatly to reducing and interrupting transmission in endemic areas leading to eventual elimination $[100,101]$. Another challenge to be faced is climate 
change and the resultant elevated temperatures which may increase the geographical distribution of the parasite through expansion of suitable environments for snails into higher altitudes and into further locations in Africa currently unaffected by the disease. While most studies focus on increasing temperature, it has been shown that snails and schistosomes within their hosts survive during the winter months and produce viable cercariae that complete their life cycles when optimal temperature is reached [102]. Furthermore, snails from temperate region demonstrate better resistance to harsh winter conditions than tropical snails [102].

\subsection{Diagnosis}

There are a number of approaches used for schistosomiasis diagnosis and schistosome detection. The standard method used in Africa is the detection of eggs in urine or stool by microscopy [103,104], although a number of immunological [105-111] and molecular [112-119] diagnostic assays have been developed with some deployed in Africa (Table 2). Polymerase chain reaction (PCR) and quantitative PCR (qPCR)-based molecular methods are now increasingly being employed for diagnosis in high-resource settings globally but they are expensive, take time, require a significant laboratory infrastructure and training which hampers their current use in low socio-economic endemic field settings. Isothermal amplification detection (IAD) methods can overcome some of these obstacles including the limitations of costly thermal cyclers required for the PCR-based detection of parasite DNA in stool or urine. IAD assays work similar to that of conventional PCR in that they utilise DNA or RNA polymerase in the extension of target-specific primers. However, isothermal amplification facilitates amplification without the repeated cycles of denaturation and annealing required for PCR. The most established IAD method for schistosome detection is loop-mediated isothermal amplification (LAMP) [120-129]. Other isothermal methods for parasite detection include helicase-dependent isothermal amplification (HDA) [130], recombinase polymerase amplification (RPA) [131] and nucleic acid sequence-based amplification (NASBA) [132], but only RPA has been applied in the detection of Schistosoma spp. [133-136].

As indicated earlier, the microscopic detection of eggs in urine (S. haematobium) and faeces (S. mansoni) is the most commonly used method for the diagnosis of schistosomiasis. The Kato-Katz (KK) method is used to detect S. mansoni eggs in faeces, while urine microscopy, preceeded by urine filtration, is used to identify S. haematobium infections $[103,104]$. S. haematobium eggs were identified in the semen of fishermen as part of a cross-sectional study along the southwestern shoreline of Lake Malawi in Sub-Saharan Africa, suggestive of high lodgement of eggs in the reproductive organs of men [76]. The precise origin of eggs found in semen is unresolved but they may have originated in the bladder, carried with drops of urine through the urethra and released with the semen [59]. Eggs of S. haematobium can be readily detected by light microscopy, and cell-free circulating schistosome DNA has been detected in semen several weeks after a single dose of PZQ [137].

In addition to egg detection, active infections can be detected from worm-derived circulating anodic antigens (CAAs) and circulating cathodic antigens (CCAs) in serum and urine using enzyme-linked immunosorbent assay (ELISA) or monoclonal- antibody-based lateral flow tests $[138,139]$. These detection methods have the ability to detect infection before the worms begin producing eggs, [140-142]. However, they do not discriminate between past, active or re-infections, especially in endemic areas where patients can remain seropositive several years after treatment $[140,143]$.

Haematuria and proteinuria reagent strip testing can also be used as indirect diagnostic methods for S. haematobium infection [144]. Strip testing has previously been shown to provide sensitivity and specificity levels of $75 \%$ and $87 \%$, respectively, for detection of S. haematobium [145] and has been suggested as an alternative form of diagnostic to the usual urine microscopy. Strip testing may be useful in sub-Saharan Africa due to its substantially higher sensitivity than microscopic methods and ease of storage of the strips [138]. 
However, the strip tests also detect haematuria not associated with S. haematobium infection, and the method exhibits poor sensitivity in detecting egg-positive urine post-treatment and low-intensity infections [138].

\section{Environmental Monitoring}

As indicated earlier, schistosomiasis is a highly focal disease with transmission being highly dependent on the presence of fresh water and appropriate snail intermediate hosts, as well as water contact activities by humans who become infected. The risk of infection is dependent on seasonal changes in snail populations, water levels, infection rates and cercarial output. Flooding events may also cause temporarily higher rates of infection in human communities. Information on snail hosts and the distribution of cercariae are important tools in the control and elimination of schistosomiasis $[3,135,146]$.

Molecular xenomonitoring is a useful disease surveillance tool for the detection of infection rates in field population of snails and could be useful in identifying infection risk areas to help guide intervention measures for schistosomiasis control and elimination [147-150]. There are a number of methods used for xenomonitoring including sentinel mice which have been used to identify transmission sites in natural water bodies in China; however, this process is time-consuming and expensive [148,151]. Morphological identification of miracidia and cercariae collected from water sources can be inaccurate due to disintegration of the larvae and misidentification of human and non-human cercariae that co-exist in most endemic areas; the latter issue is also applicable to identifying cercariae from infected snails [152] (Figure 1, Table 1).

PCR-based detection methods have been developed that detect cercariae in water samples and schistosome species in snail intermediate snail hosts, and these have proved useful in identifying and monitoring schistosomiasis transmission areas in Africa [148,153]. An example is the DraI PCR, which has been used to monitor snail transmission S. haematobium cercariae in Morocco [154]. The DraI ribosomal sequence is specific to the S. haematobium group and can detect low amounts of DNA due to its abundant sequences in the S. haematobium genome [155-158]. Another example is a two-step multiplex PCR approach which first identifies Schistosoma infected snails, followed by species-specific identification using internal transcribed spacer (ITS) rRNA primers [159,160].

\section{A Brief History of Schistosomiasis in Africa}

Schistosomiasis in Africa dates back more than 4000 years [73,161-163]. Symptoms characteristic of urinary schistosomaisis were first described in early Egyptian papyri and the eggs of $S$. haematobium were identified in the urinary tracts of mummies from 1250-1000 BC [73,161-163]. Symptoms were described as urological problems such as enlarged prostate, bladder stones, cystitis, changes in urinary frequency and discharge from the penis; this has been interpreted as blood although it could have also indicated semen, or purulent discharge from sexually transmitted diseases $[164,165]$. More recently, there were reports of persistent haematuria recorded by members of Napoleon's army in Egypt in 1798, and in forces involved in the Boer war (1899-1902) [164]. Schistosomiasis was first recorded in the Eastern Cape of South Africa in 1863, after Dr J Harley diagnosed endemic haematuria with unknown cause in local residents. He later diagnosed this as Bilharziasis after observing eggs in the urine 11 years after the official identification of the parasite [165-168]. It was described as common in the Cape and thought to be due to contact with freshwater [166,167]. Cases of haematuria later identified as schistosomiasis based on the presenting symptoms were wide-spread in South Africa between 1864 and 1899 with children particularly affected [166,169-171]. Women and girls were considered to be less affected as they had little contact with 'natural' water [166]. The geographical distribution of urogenital schistosomiasis in South Africa was later described and efforts were made to recognise the disease as a serious public health issue from the 1960s onwards [169-171]. However, government run-control programmes were essentially non-existent until the 
1990s when the first helminth control program, targeting soil-transmitted helminths as well as S. haematobium, was set up in the KwaZulu-Natal province of South Africa in 1997 [172].

The German physician Theodore Bilharz first officially identified the parasite causing schistosomiasis in 1851, after he recovered two distinct species from autopsies of dead soldiers in Egypt [165,167]. Dr Bilharz first named the parasite Distomum haematobium and also described hatching of eggs, linking the existence of the parasite to clinical symptomsprimarily haematuria-attributed to the disease [165,167]. Bilharzia was later adopted as the generic term for the schistosome parasites. In 1902, Sir Patrick Manson posited that humans could be infected with $S$. haematobium and another species of Schistosoma based on differences in egg morphology and the manner of excretion. This was not, however, officially accepted until 1915 when $S$. mansoni was established as a separate species distinct from S. haematobium by Louis Westenra Sambon who named it in honour of Sir Patrick Manson [173].

\subsection{Current Status of Schistosomiasis in Africa}

Schistosomiasis is a major ongoing public health issue particularly in sub-Saharan African countries [174] (Figure 2). S. haematobium is the most prevalent species in subSaharan Africa (Table 1) with an estimated 112 million individuals infected [175]. Nearly 71 million individuals experience haematuria, half of which have dysuria, and around 18 million infected individuals suffer from urinary bladder pathology annually [175]. Deaths resulting from kidney failure due to schistosomiasis haematobia amount to 150,000 annually [2,175]. There is an estimated 54 million individuals infected with $S$. mansoni with around 4 million people experiencing diarrhea and 8.5 million hepatomegaly [175], with deaths resulting from haematemesis estimated to be around 130,000 annually [2,175].

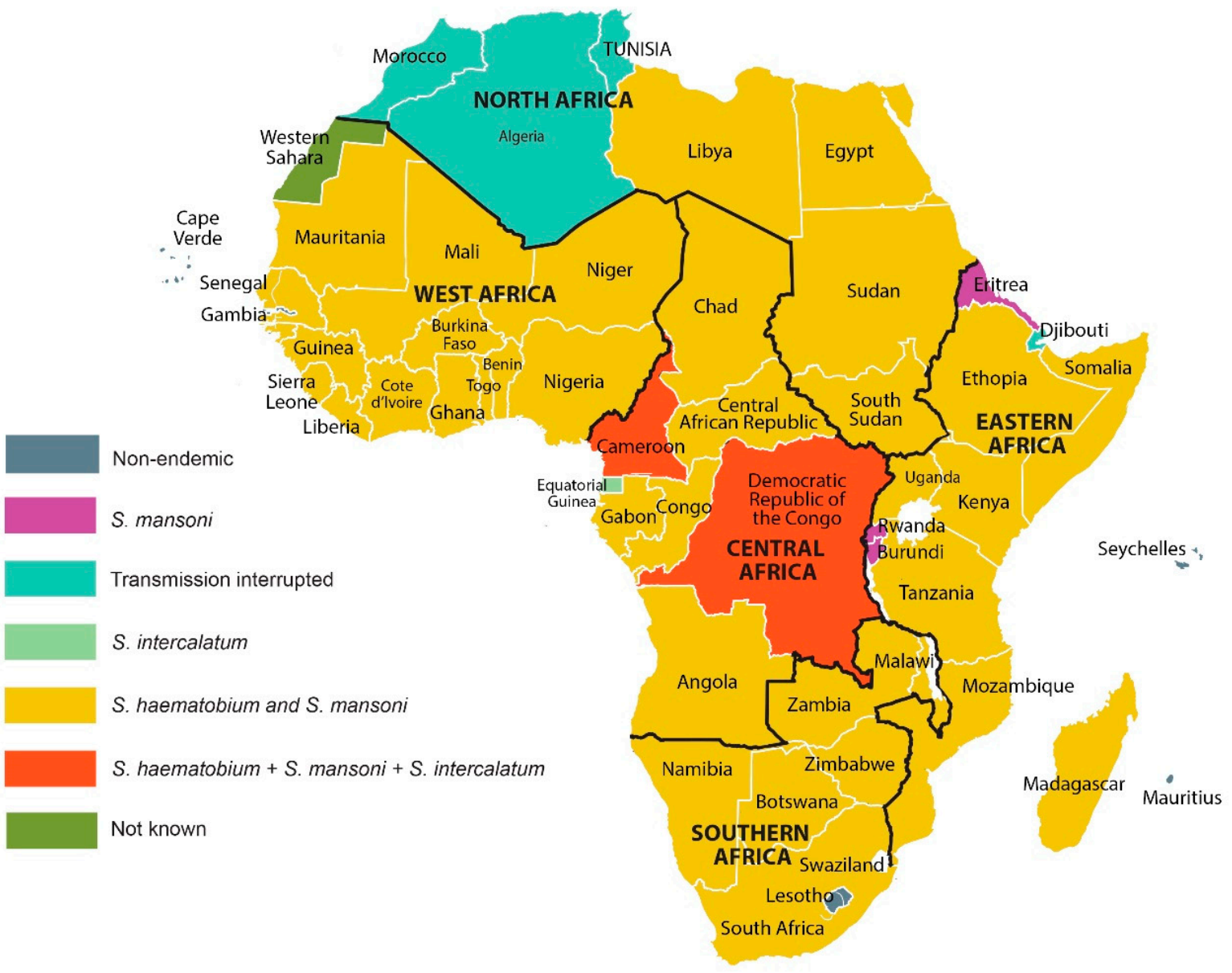

Figure 2. Distribution of schistosome infections in Africa modified from references [176,177]. 
S. haematobium and S. mansoni are geographically present together in much of Africa (Figure 2) often leading to co-infections with both parasites [175] (Table 2). Nigeria in West Africa currently has the highest schistosomiasis prevalence in the world [178], with S. mansoni and S. haematobium recorded there since 1881 [179]. Urogenital schistosomiasis is widespread throughout the country while $S$. mansoni is both less prevalent and has a reduced geographical distribution $[180,181]$. Schistosomiasis is thought to have been transmitted to Northern Nigeria by Fulani herdsmen from the Upper Nile Valley, and the distribution of the infection was first mapped out in 1963 [179,181]. A World Bank report in 1997 estimated that 25 million individuals in Nigeria were infected with S. haematobium, S. mansoni or with both species [182]. As of 2015, 29 million people were estimated infected [183]. Prevalence studies have continued, however more recent figures of infection are not available despite this [180]. S. intercalatum is also present in Nigeria [184]. A survey in Nigeria examined 47 dams in areas hyper-endemic or moderately endemic for schistosomiasis. Of these dams, 20 had the requisite intermediate molluscan hosts, indicating a need for new large scale surveys to determine the true prevalence and distribution of schistosomiasis in Nigeria [180]. Recently, a mapping project for the distribution of urogenital schistosomiasis in Anambra state, Nigeria, was undertaken [185]. Participants $(n=450)$ in the area were recruited and asked to provide a urine sample which was tested using a dipstick to identify those with haematuria and egg microscopy to gauge prevalence in the study area. Overall, the prevalence was low with $5.5 \%$ infection in individuals diagnosed by haematuria, and $2.9 \%$ by microscopic detection of eggs [185], although both tests are considered to have low sensitivity so the true prevalence was likely underestimated $[180,186]$. In Katsina State, Nigeria, the prevalence of urogenital schistosomiasis reached $22.7 \%$ in 2018 and was higher than the prevalence $(8.7 \%)$ determined in a separate study on SAC in the same area in $2016[187,188]$ (Table 2). A very high prevalence $(38.9 \%)$ was determined in Imo state in Oguta, although this report is nearly 20 years old [189]. Thus, reports of schistosomiasis in Nigeria are scattered, with limited recent studies and differing methodology used making it difficult to compare studies and to accurately estimate true overall country prevalence (Table 2). 


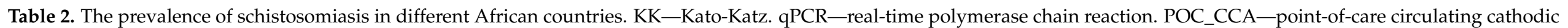
antigen. DDIA—dipstick dye immunoassay. IHA—indirect hemagglutination assay. Ss/Sp—sensitivity/specificity.

\begin{tabular}{|c|c|c|c|c|c|c|c|c|c|c|c|c|}
\hline \multirow[t]{2}{*}{ Country } & \multirow[t]{2}{*}{ Method } & \multirow[t]{2}{*}{ Species } & \multirow[t]{2}{*}{ Prevalence \% (n/tn) } & \multirow[t]{2}{*}{ Ss/sp (\%) } & \multirow[t]{2}{*}{ Study Type } & \multirow[t]{2}{*}{ Age (years) } & \multicolumn{3}{|c|}{ Intensity of Infection (\%) } & \multirow[t]{2}{*}{ Study Year } & \multirow[t]{2}{*}{ Study Published } & \multirow[t]{2}{*}{ References } \\
\hline & & & & & & & Light & Mode rate & High & & & \\
\hline \multirow{4}{*}{ Angola } & Urine microscopy & S. haematobium & $61.18(785 / 1283)$ & - & \multirow{3}{*}{$\begin{array}{l}\text { Cross-sectional } \\
\text { survey }\end{array}$} & \multirow{3}{*}{$9-10$} & - & - & - & \multirow{3}{*}{ 2013-2014 } & \multirow{3}{*}{2015} & \multirow{3}{*}{ [190] } \\
\hline & Urine dipstick & S. haematobium & $65.8(844 / 1283)$ & $96 / 61$ & & & - & - & - & & & \\
\hline & Haematuria & S. haematobium & $17.1(219 / 1283)$ & $27.1 / 97.5$ & & & - & - & - & & & \\
\hline & LAMP & S. haematobium & $73.8(127 / 172)$ & - & Evaluation & 5-14 & - & - & - & 2015 & 2018 & [191] \\
\hline \multirow{2}{*}{ Benin } & KK & S. mansoni & $2.45(472 / 19250)$ & - & \multirow{2}{*}{ Surveillance } & \multirow{2}{*}{$8-14$} & 59.32 & 25.42 & 15.25 & \multirow{2}{*}{ 2013-2015 } & \multirow{2}{*}{2019} & \multirow{2}{*}{ [192] } \\
\hline & Urine microscopy & S. haematobium & $17.60(3388 / 19250)$ & - & & & 73.99 & - & 20.01 & & & \\
\hline Burkina Faso & KK & S. mansoni & $5.38(43 / 800)$ & - & Prevalence & $7-11$ & - & - & - & 2013 & 2016 & [193] \\
\hline & KK & S. mansoni & $61(381 / 625)$ & - & & & - & - & - & & & \\
\hline Compron & Urine-CCA & S. mansoni & $66.6(416 / 625)$ & - & & & - & - & - & & & [1101] \\
\hline Cameroon & Urine microscopy & S. haematobium & $4.6(29 / 625)$ & - & Evaluation & $7-15$ & - & - & - & 2010-2011 & 2012 & [110] \\
\hline & Dipstick & S. haematobium & $9.8(61 / 625)$ & - & & & - & - & - & & & \\
\hline Chad & Urine microscopy & S. haematobium & $24.9(467 / 1875)$ & - & Prevalence & $1-14$ & - & - & - & 2015-2016 & 2019 & [194] \\
\hline & Urine microscopy & S. haematobium & $14(166 / 1187)$ & - & Cross-sectional & $5-14$ & - & - & - & 2018 & 2019 & [195] \\
\hline & KK & S. mansoni & $6.1(66 / 1089)$ & - & survey & $5-14$ & - & - & - & 2018 & 2019 & [190] \\
\hline Côte d'Ivoire & CCA & S. mansoni & $73.8(104 / 141)$ & - & Cross-sectional & $8-12$ & - & - & - & 2010 & 2011 & [109] \\
\hline & KK & S. mansoni & $82.7(277 / 335)$ & - & $\begin{array}{l}\text { Epidemiology/ } \\
\text { parasitology }\end{array}$ & $8-16$ & 43.2 & 32 & 24.7 & 2011 & 2014 & [196] \\
\hline & KK & S. mansoni & $8.9(47 / 526)$ & - & Cross-sectional & $7-13$ & 8.8 & - & - & 2016 & 2017 & [197] \\
\hline & Urine microscopy & S. haematobium & $0(0 / 526)$ & - & survey & $1-13$ & - & - & - & 2016 & 2017 & {$[19 /]$} \\
\hline & Urine microscopy & S. haematobium & $17.4(64 / 367)$ & - & $\begin{array}{l}\text { Cross-sectional } \\
\text { survey }\end{array}$ & $>18$ & - & - & 6.3 & 2016-2017 & 2019 & [198] \\
\hline $\begin{array}{l}\text { Democratic Republic } \\
\text { of the Congo }\end{array}$ & KK & S. mansoni & $89.3(176 / 197)$ & - & $\begin{array}{l}\text { Cross-sectional } \\
\text { survey }\end{array}$ & $11-14$ & 11.7 & 22.3 & 55.3 & 2011 & 2018 & [199] \\
\hline & KK & S. mansoni & $57.8(231 / 400)$ & - & $\begin{array}{l}\text { Cross-sectional } \\
\text { survey }\end{array}$ & $9-14$ & 18.6 & 28.6 & 52.8 & 2010 & 2016 & [200] \\
\hline & KK & S. intercalatum & $48(24 / 50)$ & - & Prevalence & $9-15$ & 50 & 20.8 & 29.2 & & 2017 & [201] \\
\hline & KK & S. intercalatum & $3.6(6 / 167)$ & - & $\begin{array}{l}\text { Epidemiological/ } \\
\text { parasitological } \\
\text { survey }\end{array}$ & $8-18$ & - & - & - & 1994 & 1997 & [202] \\
\hline
\end{tabular}


Table 2. Cont

\begin{tabular}{|c|c|c|c|c|c|c|c|c|c|c|c|c|}
\hline Country & Method & Species & Prevalence $\%(\mathrm{n} / \mathrm{tn})$ & Ss/sp (\%) & Study Type & Age (years) & \multicolumn{3}{|c|}{ Intensity of Infection (\%) } & Study Year & Study Published & References \\
\hline \multirow{4}{*}{ Egypt } & KK & S. mansoni & $35.8(355 / 993)$ & - & $\begin{array}{c}\text { Cross-sectional } \\
\text { survey }\end{array}$ & - & - & - & - & 1994-1996 & 2020 & [203] \\
\hline & KK & S. mansoni & $1.8(2 / 110)$ & - & \multirow{3}{*}{ Prevalence } & \multirow{3}{*}{$6-15$} & - & - & - & - & \multirow{3}{*}{2016} & \multirow{3}{*}{ [204] } \\
\hline & Formol-ether & S. mansoni & $0.9(1 / 110)$ & - & & & - & - & - & - & & \\
\hline & CCA & S. mansoni & $11.4(4 / 110)$ & - & & & - & - & - & - & & \\
\hline \multirow[b]{3}{*}{ Equitorial Guinea } & KK & S. intercalatum & $31.9(114 / 357)$ & - & \multirow{3}{*}{ Evaluation } & \multirow{3}{*}{$15-24^{*}$} & - & - & 4.7 & 1988 & \multirow{3}{*}{1991} & \multirow{3}{*}{ [205] } \\
\hline & KK & S. intercalatum & $9.6(27 / 281)$ & - & & & - & - & 0.7 & 1989 & & \\
\hline & KK & S. intercalatum & $6.6(23 / 345)$ & - & & & - & - & 0.2 & 1990 & & \\
\hline \multirow{4}{*}{ Ethiopia } & KK & S. mansoni & $42.9(136 / 317)$ & - & \multirow{4}{*}{$\begin{array}{l}\text { Cross-sectional } \\
\text { survey }\end{array}$} & 6-15 & 20.5 & 10.7 & 11.7 & 2017 & 2019 & [207] \\
\hline & KK & S. mansoni & $76.3(293 / 384)$ & - & & 5-19 & 21.6 & 29.4 & 25.5 & 2013 & 2014 & [208] \\
\hline & KK & S. mansoni & $24(120 / 500)$ & - & & $6-18$ & 70 & 30 & 20 & 2014 & 2016 & [209] \\
\hline & KK & S. mansoni & $58.6(295 / 503)$ & - & & 5-19 & 34.2 & 35.5 & 30 & 2015 & 2017 & [210] \\
\hline \multirow{3}{*}{ Gabon } & Urine microscopy & S. haematobium & $77.7(66 / 85)$ & - & \multirow{2}{*}{ Evaluation } & 6-39 & - & - & 34.8 & \multirow{2}{*}{-} & \multirow{2}{*}{2014} & \multirow{2}{*}{ [211] } \\
\hline & qPCR & S. haematobium & $98.5(65 / 66)$ & - & & & - & - & - & & & \\
\hline & Urine microscopy & S. haematobium & $39.9(103 / 258)$ & - & Longitudinal & $6-30$ & - & - & - & 2016-2018 & 2019 & [212] \\
\hline \multirow{3}{*}{ Gambia } & POC-CCA & S. haematobium & $23.3(456 / 1954)$ & $47.98 / 79.44$ & \multirow{2}{*}{ Prevalence } & \multirow{2}{*}{$7-14$} & - & - & - & \multirow{2}{*}{2015} & \multirow{2}{*}{2017} & \multirow{2}{*}{ [213] } \\
\hline & Urine microscopy & S. haematobium & $10.1(198 / 1954)$ & - & & & - & - & 2.7 & & & \\
\hline & KK & S. mansoni & $0.3(5 / 1954)$ & $60 / 76.76$ & & & - & - & 0 & & & \\
\hline \multirow{11}{*}{ Ghana } & \multirow{2}{*}{ qPCR } & S. haematobium & $48.5(79 / 163)$ & $100 / 59.2$ & Prevalence & & & & & & \multirow{2}{*}{2020} & [214] \\
\hline & & S. mansoni & $28.7(94 / 328)$ & - & Epidemiology/Prevalen & ce $7-17$ & 50 & 35.1 & 11.7 & 2017 & & {$[214]$} \\
\hline & & & $70.1(54 / 77)$ & - & & C & - & - & - & & & \\
\hline & & 5. mansonı & $7.9(9 / 108)$ & & & $0-4$ & & & & & & \\
\hline & & & $13.7(13 / 96)$ & & & & & & & & & \\
\hline & & & $80.1(153 / 191)$ & - & & & - & - & - & & & \\
\hline & & 5. mansone & $39.9(89 / 224)$ & & Longitudinal & $5-16$ & & & & 2018 & 2020 & [215] \\
\hline & & & $35.9(86 / 240)$ & & & & & & & & & \\
\hline & & & $79.1(200 / 253)$ & - & & & - & - & - & & & \\
\hline & & 5. mansone & $32.1(107 / 332)$ & & & $>17$ & & & & & & \\
\hline & & & $34.8(100 / 286)$ & & & & & & & & & \\
\hline
\end{tabular}


Table 2. Cont

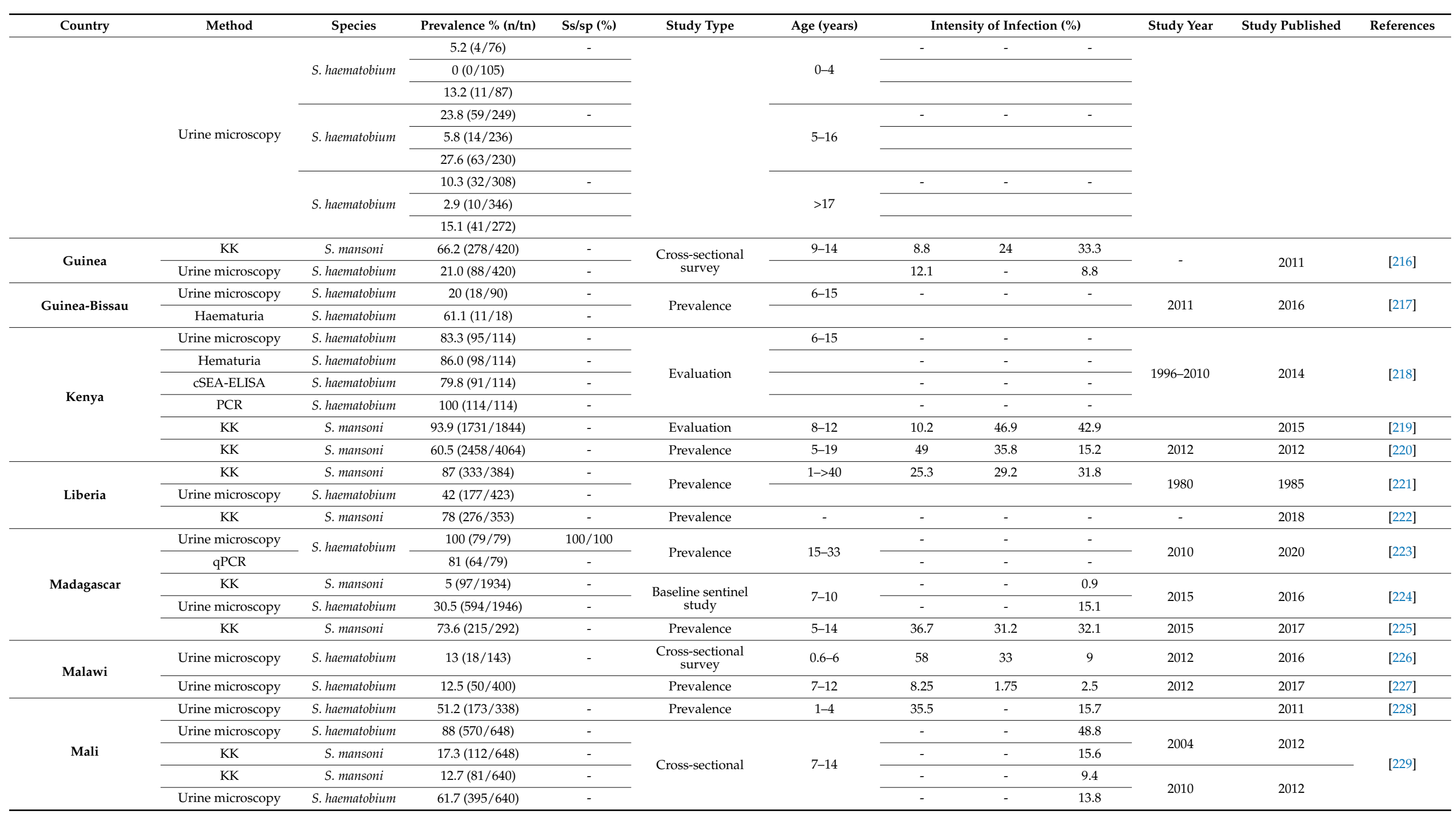


Table 2. Cont.

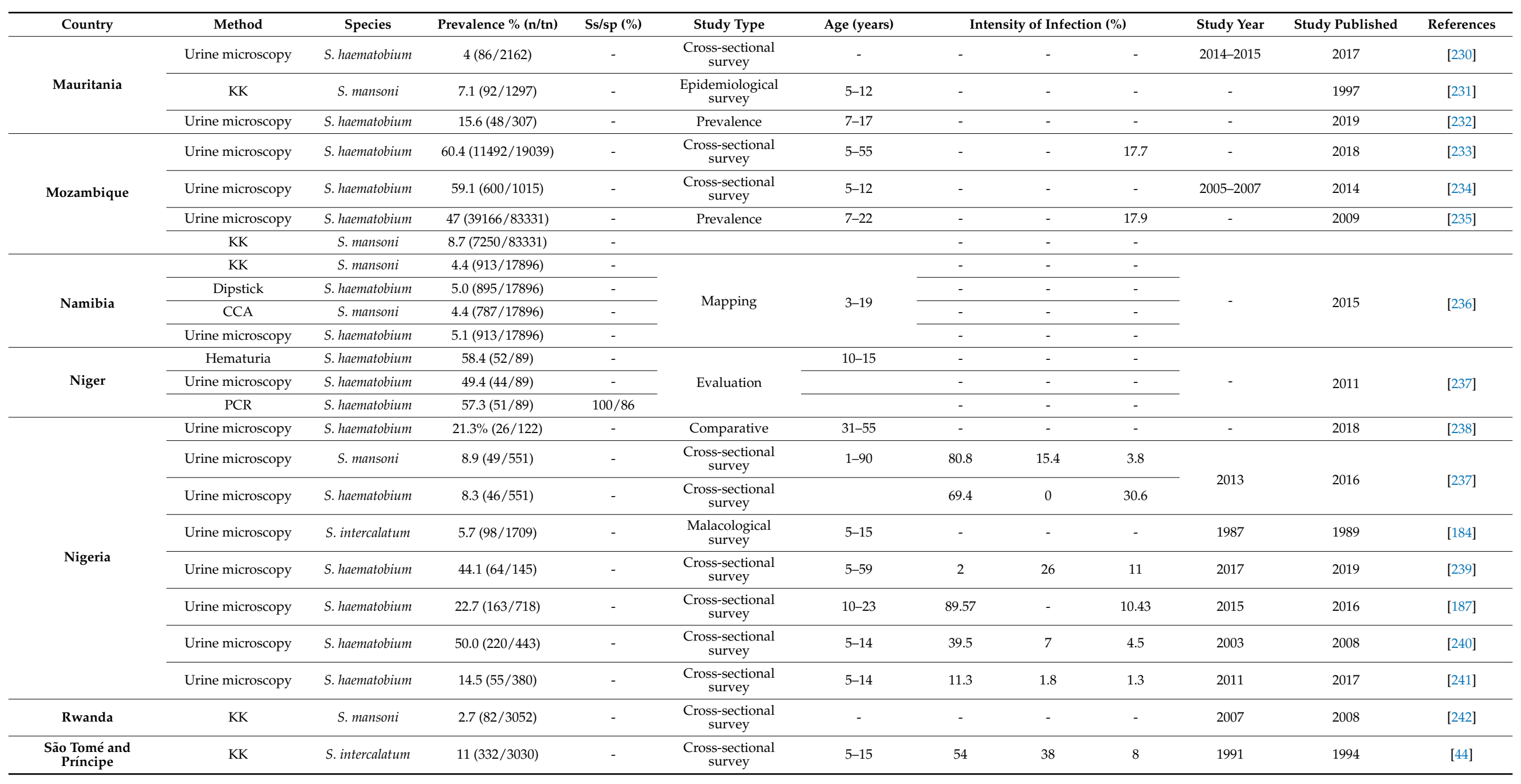


Table 2. Cont

\begin{tabular}{|c|c|c|c|c|c|c|c|c|c|c|c|c|}
\hline Country & Method & Species & Prevalence $\%(n / t n)$ & Ss/sp (\%) & Study Type & Age (years) & \multicolumn{3}{|c|}{ Intensity of Infection (\%) } & Study Year & Study Published & References \\
\hline \multirow{3}{*}{ Senegal } & KK & S. mansoni & $80(70 / 88)$ & - & Evaluation & $2-83$ & 54.55 & 15.9 & 9.1 & \multirow{3}{*}{2006} & \multirow{3}{*}{2008} & \multirow{3}{*}{ [243] } \\
\hline & Urine microscopy & S. haematobium & $72(63 / 88)$ & - & & & 50 & - & 21.6 & & & \\
\hline & qPCR & S. mansoni & $73(64 / 88)$ & - & & & - & - & - & & & \\
\hline \multirow{8}{*}{ South Africa } & Urine microscopy & S. haematobium & $19.8(78 / 394)$ & - & \multirow{2}{*}{ Prevalence } & \multirow{2}{*}{$16-23$} & - & - & - & \multirow{2}{*}{ 2010-2012 } & \multirow{2}{*}{2020} & \multirow{2}{*}{ [223] } \\
\hline & qPCR & & $23.1(91 / 394)$ & - & & & - & - & - & & & \\
\hline & Urine microscopy & S. haematobium & $1.0(11 / 1143)$ & - & \multirow{2}{*}{$\begin{array}{c}\text { Cross-sectional } \\
\text { survey }\end{array}$} & \multirow{2}{*}{$1-5$} & - & - & - & \multirow{2}{*}{2018} & \multirow{2}{*}{2019} & \multirow{2}{*}{ [244] } \\
\hline & KK & S. mansoni & $0.9(9 / 998)$ & - & & & - & - & - & & & \\
\hline & Urine microscopy & S. haematobium & $40.2(169 / 380)$ & - & Prevalence & $10-15$ & 61 & - & - & 2014 & 2018 & [245] \\
\hline & Urine microscopy & S. haematobium & $31.8 \%(225 / 708)$ & - & \multirow{2}{*}{$\begin{array}{l}\text { Cross-sectional } \\
\text { survey }\end{array}$} & \multirow{2}{*}{$10-12$} & - & - & 26.7 & \multirow{2}{*}{ 2009-2010 } & \multirow{2}{*}{2014} & \multirow{2}{*}{ [246] } \\
\hline & qPCR & S. haematobium & $25.4(180 / 708)$ & - & & & - & - & - & & & \\
\hline & Urine microscopy & S. haematobium & $37.5(120 / 320)$ & - & Prevalence & $10-15$ & - & - & - & 2015 & 2017 & [247] \\
\hline \multirow{3}{*}{ Sudan } & KK & S. mansoni & $36(1020 / 2832)$ & - & Cross-sectional & $10-24$ & - & - & - & - & 1993 & [248] \\
\hline & Urine microscopy & S. haematobium & $38.9(58 / 149)$ & - & \multirow{2}{*}{ Comparative } & \multirow{2}{*}{$5->20$} & - & - & 2 & \multirow{2}{*}{ 2011-2013 } & \multirow{2}{*}{2018} & \multirow{2}{*}{ [249] } \\
\hline & ELISA & S. haematobium & $81.2(119 / 149)$ & - & & & - & - & - & & & \\
\hline \multirow{2}{*}{ Swaziland } & Urine microscopy & S. haematobium & $5.3(21 / 395)$ & - & Prevalence & $6-12$ & - & - & - & 2010 & 2011 & [250] \\
\hline & Urine microscopy & S. haematobium & $6.1(18 / 295)$ & - & 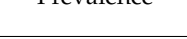 & $<5->19$ & - & - & - & - & 2010 & [251] \\
\hline & qPCR & S. mansoni & $92.9(276 / 297)$ & $98.7 / 81.2$ & $\begin{array}{l}\text { Cross-sectional } \\
\text { survey }\end{array}$ & $7-16$ & - & - & - & 2015 & 2018 & [252] \\
\hline & POC_CCA & & $94.9(282 / 297)$ & $99.5 / 63.4$ & & & - & - & - & & & \\
\hline & KK & S. mansoni & $68.9(641 / 930)$ & - & Cross-sectional & $1-95$ & 55.2 & 20.4 & 12.9 & 2016 & 2019 & [253] \\
\hline & POC_CCA & S. mansoni & $94.5(878 / 929)$ & - & survey & 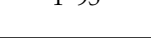 & - & - & - & 2010 & 2013 & [200] \\
\hline Tanzania & KK & S. mansoni & $90.6(752 / 830)$ & - & $\begin{array}{l}\text { Cross-sectional } \\
\text { survey }\end{array}$ & $5-19$ & 24.1 & 38.4 & 28.1 & 2017 & 2020 & [254] \\
\hline & KK & S. mansoni & $15.1(898 / 5952)$ & - & Cross-sectional & $7-16$ & - & - & - & - & 2015 & {$[255]$} \\
\hline & Urine microscopy & S. haematobium & $8.9(519 / 5952)$ & - & survey & $7-10$ & - & - & - & - & 2010 & [200] \\
\hline & KK & S. mansoni & $84.01(431 / 513)$ & - & $\begin{array}{c}\text { Cross-sectional } \\
\text { survey }\end{array}$ & & 34.11 & 39.91 & 25.99 & - & 2016 & [256] \\
\hline & Urine microscopy & S. haematobium & $11.6(13 / 112)$ & - & & $6-16$ & - & - & - & 2009-2010 & & \\
\hline & qPCR & S. haematobium & $19.6(22 / 112)$ & - & Prevalence & & - & - & - & - & 2020 & [223] \\
\hline & KK & S. mansoni & $1.3(4 / 310)$ & - & & & - & - & - & - & & \\
\hline
\end{tabular}


Table 2. Cont

\begin{tabular}{|c|c|c|c|c|c|c|c|c|c|c|c|c|}
\hline Country & Method & Species & Prevalence $\%(n / t n)$ & Ss/sp (\%) & Study Type & Age (years) & & of Inf & & Study Year & Study Published & References \\
\hline \multirow{8}{*}{ Uganda } & $\begin{array}{l}\text { Urine-CCA } \\
\text { Dipstick }\end{array}$ & S. mansoni & $56.7(146 / 258)$ & $99.1 / 89.3$ & \multirow{2}{*}{ Surveillance } & \multirow{2}{*}{$5-10$} & - & - & - & - & \multirow{2}{*}{2018} & \multirow{2}{*}{ [257] } \\
\hline & SEA ELISA & S. mansoni & $75.1(193 / 258)$ & $97.7 / 49.5$ & & & - & - & - & - & & \\
\hline & KK & S. mansoni & $39.3(1203 / 3058)$ & - & Prevalence & $1-5$ & 60.7 & 21.8 & 17.5 & 2012-2013 & 2015 & {$[258]$} \\
\hline & KK & S. mansoni & $40.8(1850 / 4534)$ & - & Prevalence & $10-14$ & - & - & - & 2009-2010 & 2011 & [259] \\
\hline & KK & S. mansoni & $27.2(352 / 1295)$ & - & \multirow{4}{*}{ Prevalence } & \multirow{2}{*}{$0.4-6.5$} & 18.7 & 6 & 2.5 & \multirow{3}{*}{2009} & \multirow{3}{*}{2010} & \multirow[b]{3}{*}{ [260] } \\
\hline & ELISA & S. mansoni & $66(38 / 58)$ & - & & & - & - & - & & & \\
\hline & KK & S. mansoni & $47.6(342 / 719)$ & - & & $15-70$ & 29.2 & 12.7 & 5.7 & & & \\
\hline & Urine microscopy & S. haematobium & $2.51(24 / 955)$ & - & & $5-17$ & - & - & - & 2007-2011 & 2018 & [261] \\
\hline \multirow{7}{*}{ Zambia } & Urine microscopy & S. haematobium & $61(90 / 147)$ & - & \multirow{4}{*}{ Evaluation } & \multirow{4}{*}{$7-14$} & 26 & - & 19 & - & \multirow{4}{*}{2020} & \multirow{4}{*}{ [262] } \\
\hline & KK & S. mansoni & $0.01(2 / 147)$ & - & & & - & - & - & & & \\
\hline & DDIA & S. haematobium & $51(75 / 146)$ & $60 / 61$ & & & - & - & - & & & \\
\hline & IHA & & $56(82 / 146)$ & $74 / 72$ & & & - & - & - & & & \\
\hline & Urine microscopy & S. haematobium & $20.7(328 / 1583)$ & - & Prevalence & 5-17 & - & - & - & 2007 & 2010 & [263] \\
\hline & Urine microscopy & S. haematobium & $28.6(279 / 975)$ & - & Prevalence & $9-16$ & 84.9 & - & 15.1 & $(2007-2015)$ & \multirow{2}{*}{2018} & \multirow{2}{*}{ [264] } \\
\hline & Urine microscopy & S. haematobium & $31.5(494 / 1570)$ & - & Prevalence & $9-15$ & 75.5 & - & 24.3 & 2011-2015 & & \\
\hline \multirow{7}{*}{ Zimbabwe } & KK & S. mansoni & $11.0(10 / 91)$ & - & \multirow{3}{*}{ Comparative } & $1-12$ & 2.1 & 8.8 & - & \multirow{3}{*}{2012} & \multirow{3}{*}{2014} & \multirow{3}{*}{ [266] } \\
\hline & Urine microscopy & S. haematobium & $52.8(48 / 91)$ & - & & & 41.8 & - & 11 & & & \\
\hline & SmCTF-RDT & Schistosoma spp & $83.5(76 / 91)$ & - & & & - & - & - & & & \\
\hline & Urine microscopy & S. haematobium & $18.0(2347 / 13037)$ & - & \multirow{2}{*}{$\begin{array}{l}\text { Cross-sectional } \\
\text { survey }\end{array}$} & $10-15$ & 12.4 & - & 5.6 & \multirow{2}{*}{ 2010-2011 } & \multirow{2}{*}{2014} & \multirow{2}{*}{ [267] } \\
\hline & KK & S. mansoni & $7.2(882 / 12249)$ & - & & & 3.6 & 1.4 & 0.3 & & & \\
\hline & Urine microscopy & S. haematobium & $18.7(61 / 325)$ & - & \multirow{2}{*}{$\begin{array}{l}\text { Cross-sectional } \\
\text { survey }\end{array}$} & $17-49$ & 93.4 & - & 6.6 & \multirow{2}{*}{ 2016-2017 } & \multirow{2}{*}{2019} & {$[5<0$} \\
\hline & Urine microscopy & S. haematobium & $13.3(71 / 535)$ & - & & $<5$ & 93 & - & 7 & & & {$[200]$} \\
\hline
\end{tabular}


Tanzania has the second highest prevalence of schistosomiasis in Africa with about $23^{\prime}$ million people infected, and is co-endemic for S. haematobium and S. mansoni [147,269]. S. hematobium is more prevalent throughout the country, especially in coastal areas $[269,270]$ while S. mansoni is more focal and widely distributed along the shores and islands of large water bodies, including Lake Victoria [269,271-273]. The entire Tanzanian population is at risk of infection due to the country-wide distribution of the disease.

The Democratic republic of Congo (DRC) in Central Africa and Ghana has the third highest number (15 million) cases of schistosomiasis in Africa [25]; S. mansoni, S. haematobium and S. intercalatum are endemic (Table 2). Despite a relative paucity of studies, the trend appears to have been a spread of schistosomiasis from formally endemic areas to new areas over the last 60 years [274,275]. The most recent reports on prevalence in the DRC come from two cross-sectional surveys performed in 2016-2017 [197,276].

Both S. haematobium and S. mansoni are prevalent in in Ghana $[214,215,277]$. A recent longitudinal study involving 2623 participants including pre-school aged children (preSAC), SAC and adults in Ghana recorded an overall prevalence of $44.2 \%$ for $S$. mansoni and $11.9 \%$ for S. haematobium, with SAC recording the highest S. haematobium prevalence [215]. The adult participants had a significantly higher prevalence of $S$. mansoni across the three sampling sites due to local economic activities and differences in snail habitat in the communities increasing the risk of infection [215] (Table 2).

In North Africa and the Middle East, it is estimated that 12.7 million individuals have schistosomiasis [11,278]. Egypt previously had the highest number of recorded schistosomiasis cases in northern Africa for a long period but has recorded reduced prevalence in recent years due to successful implementation of control and elimination initiatives [279]. Morocco and Tunisia have successfully achieved transmission interruption of the disease (Figure 2) [280-283]. This came about through effective chemotherapy treatment programs, as well as targeted snail control programs and the use of molluscicides [281]. Elsewhere in North Africa, Algeria still awaits WHO confirmation of schistosomiasis interruption, as noted in the 2001-2011 WHO progress report, citing no new cases for ten years [284]. However, in 2003, it was estimated that $23.4 \%$ of the Algerian population was at risk of infection and 2.4 million were estimated to be infected [11]. There are no recent reports on schistosomiasis in Algeria and it is unclear if surveillance for the disease is being carried out; thus its true status remains unclear.

In East and Southeast Africa, S. mansoni is the dominant species present (Figure 2, Table 2). S. mansoni was first reported in Uganda in 1902 and high incidences of S. mansoni infection were reported in 1924; infection rates remained high in 1958 [285-288]. In 1949, an extraordinary $S$. mansoni prevalence of $95.2 \%$ was recorded in men around Lake Mobutu in Uganda, with all fishermen tested found to be infected [289]. S. haematobium and S. mansoni are both highly prevalent in Uganda while $S$. intercalatam was reported in some areas in 1978 [290] (Table 2). Recent reports of schistosomiasis in Uganda have focussed primarily on S. mansoni due to its increasing country prevalence, while S. haematobium has a more localised sporadic occurrence [285]. The prevalence of S. mansoni in Ethiopia remains high with recent surveys reporting prevalence levels between $24-76.3 \%$ determined using the KK procedure (Table 2). Similar to Tanzania, Mozambique is endemic for both S. mansoni and S. haematobium, however the prevalence of S. haematobium is higher in Mozambique, whereas S. mansoni is more prevalent in Tanzania (Table 2).

The prevalence of schistosomiasis in South Africa is generally high but low among pre-SAC (Table 2). A 2018 survey in KwaZulu-Natal recorded a prevalence of 1\% for S. haematobium and $0.9 \%$ for S. mansoni among pre-SAC [291], while a cross-sectional study in 2017 determined 37.5\% prevalence among SAC (Table 2). Another study in 2014 recorded a high prevalence of $31.8 \%$ of $S$. haematobium prevalence among girls aged 10-12 years by urine microscopy [246], while a report published in 2020 recorded a slightly lower prevalence of $19.8 \%$ for $S$. haematobium using urine microscopy and $23.1 \%$ by qPCR among young women aged 16 to 23 years [223] (Table 2). Swaziland and Zambia have high 
prevalence of S. haematobium, while both S. haematobium and S. mansoni are endemic in Zimbabwe, Namibia and Malawi (Table 2).

Another hindrance to control is the crucial lack, in a number of sub-Saharan countries, of reliable and accurate data on the prevalence, intensity of infection, epidemiology, and geographic spread of schistosomiasis. This is partly due to inadequate or a complete lack of surveillance and monitoring of the disease which leads to an inability to predict transmission areas and identify vulnerable populations [291-293]. Whereas national control programs have been put in place in many African nations, led by the Schistosomiasis Control Initiative [294], political instability, complacency and inadequate funding for control activities have led to re-emergence and even an increase in infection rates in some areas $[27,285,295]$. Nevertheless, transmission has been successfully interrupted in some regions of Africa who await verification from WHO confirming elimination (Figure 1) [154,280,281,284].

One of the real success stories in Africa is Morocco, which recorded transmission interruption in 2004, with no new cases in Moroccan natives recorded since $[154,280,281]$. In Burkina Faso, there has been a decline in the prevalence of schistosomiasis in SAC as a result of a decade of PC with PZQ [193,284]. A 2016 study to assess the impact of a decade of biennial MDA, and four and five rounds of PZQ per year in hyperendemic zones, showed that Burkina Faso had greatly reduced the prevalence and intensity of $S$. haematobium $[193,284]$. Indeed, based on WHO criteria, Burkina Faso has eliminated urogenital schistosomiasis as a public health concern in 8 out of its 13 regions $[193,284]$. Despite this success, prevalence still remains high in some areas, with $34.38 \%$ of surveyed SAC in the Central-East infected with S. haematobium and $20.94 \%$ in Sahel [193]. S. mansoni was identified in only two regions, with most infections occurring in Central-East region [193].

3.2. Stigmatisation Associated with Schistosomiasis, Particularly in Women Is still a Crucial Issue in Africa

The majority of schistosomiasis studies indicate no significant differences between the disease in males and females. However, it has been suggested that estimates of disease burden of schistosomiasis in females has been underreported [296-298]. One of the challenges still faced in Africa is gender disparity. Illiteracy, lack of education and lower economic and social status are still more common among African women than men [296,298-300]. Men are most often exposed to infection due to their occupations as farmers and fishermen. However, women also come in contact with cercariae regularly during washing or when they fetch water for domestic use in areas that lack a potable water supply. This frequent contact with water leaves them at risk of heavy infections that could cause permanent damage. The social consequences of schistosomiasis are also more severe in women than in men. For instance, haematuria resulting from S. haematobium infection, is still considered a sign of 'coming of age' in certain regions of Africa [20,21]. Some classify haematuria as a sign of sexually transmitted infection, while others consider it as a curse or witchcraft [20]. This perception is highly influenced by the level of education and local cultural beliefs [301]. A study among women reported that the presence of haematuria in urine is considered as part of menstruation, and is hence not regarded as a disease [301]. Several communities in Africa still view diagnosis of schistosomiasis in women as inappropriate, as they may be required to be subjected to physical examination or provide urine or stool samples [298]. In general, discussions about the influence of gender on NTD control programmes and interventions are limited, and if the issue of gender disparity and early intervention around diagnosis are not addressed, the true prevalence of schistosomiasis in women will remain uncertain, leading to issues governing treatment and control options in many communities [302,303].

\subsection{Hybrid Schistosomes}

Hybridization and introgression events have been identified in a range of organisms including schistosomes [8,304-308]. Acquisition of new genes due to hybridization can lead to development of new phenotypes that can change the pathology, virulence, hosts, and 
resistance of the parasite [306]. Schistosomiasis is a highly focal disease due to requirements of specific intermediate molluscan and definitive hosts, restricting schistosome species to ecological niches which restricts hybridization events. However, both natural and manmade changes have the ability to breakdown ecological hurdles (see section below, 4.0 Factors that determine the distribution of schistosomiasis in Africa), thereby introducing these parasite species and strains to new areas which can result in novel interactions between the hosts and parasites leading to hybridization events.

Among the human schistosome species, hybridization has been most commonly observed between S. haematobium and S. intercalatum. Prior to 1969, S. intercalatum was the only schistosome species present in Loum, a small town in Cameroon [307]. However, after increased haematuria in the population, a symptom usually associated with S. haematobium, it was discovered that introgressive hybridization had occurred, replacing S. intercalatum with S. haematobium [307]. This is due to the higher competitive fitness of male $S$. haematobium worms to mate with female $S$. intercalatum worms $[9,309]$.

Additionally, it has been reported that the two strains of $S$. intercalatum found in Africa (Cameroon and DRC), exhibit different characteristics [310-315]. Kane and colleagues [315] carried out phylogenetic analysis utilizing the cytochrome oxidase subunit 1 (cox1), NADH dehydrogenase subunit 6 (nad6) and the small ribosomal RNA gene ( $r r n S$ ) from the mitochondrial DNA of the two recognised strains of $S$. intercalatum and proposed that the strains should be treated as distinct taxa, with one of the strains, the DRC strain closer to $S$. haematobium and the West African strain aligning closer to the animal schistosomes S. bovis and S. curassoni. Phylogenetic information from this report was similar to an earlier study where random amplified polymorphic DNA (RAPD) markers were used to examine both $S$. intercalatum strains, which also reported significant differences between the two [316].

Molecular sequencing of eggs isolated from human stools and urine in northern Senegal revealed $15 \%$ of the eggs had hybrid genotypes, with fragments partially identical to S. haematobium and S. bovis [306]. Another Senegalian study, involving three closely related species: human $S$. haematobium and ruminant $S$. bovis and S. curassoni revealed the presence of S. haematobium/S. curassoni and S. haematobium/S. bovis hybrids in nearly $90 \%$ of the children surveyed; no S. haematobium hybrids were observed in ruminants, although S. bovis / S. curassoni hybrids were identified in these animals [8]. The hybridisation events were hypothesized to have occurred in this area due to ecological and climate changes leading to overlapping areas of distribution of these schistosome species and their intermediate and definitive hosts [8]. A study in two villages in the Republic of Benin also reported an introgression of S. guineensis genes in S. haematobium [317].

Hybridization and introgression events can influence the epidemiology of schistosomiasis in a number of ways, including the potential for new zoonotic forms to emerge, with important implications for control, as well as changes in pathogenicity, drug sensitivity, and parasite transmission.

\subsection{Control Measures in addition to MDA Utilised in Africa}

\subsubsection{Mapping Studies and Snail Control}

Mapping and geospatial analysis of schistosomiasis is important to monitor transmission trends and prevalence, leading to better understanding of the disease burden and risk factors for infection, which will in turn result in more targeted control efforts and improved surveillance procedures. Mapping studies have gradually increased in Africa [201,259,318-322]. Communities that have performed mapping have been able to effectively scale up treatment and monitor applied control strategies [21]. Most reports focus on SAC, while a small number carried out on pre-SAC and adults indicate that these age groups are also at high risk of infection as they are constantly exposed to water bodies infested with cercariae $[323,324]$. Prevalence-based studies that exclude pre-SAC and adults can lead to reduced treatment levels during MDA, thus making these groups potential reservoirs of infection, leading to ongoing transmission risk to all ages. 
It is now generally recognised that integrated strategies for schistosomiasis control and multisectoral approaches will be required to achieve elimination and these strategies have been increasingly advanced over the years [325-328]. Accurate data on parasite distribution, prevalence, at risk populations and other vulnerable groups including pre-SAC children will play important roles in the design of effective control measures. However, disease surveillance in low socio-economic endemic areas is greatly affected by low quality disease data as a result of underestimating infection rates due to inadequate health infrastructure, low parasite burden and reduced symptoms resulting from MDA and PZQ treatment. Predictive modelling can provide relevant information to aid in designing action plans for integrated and targeted control of schistosomiasis in many endemic areas.

Environmental factors including vegetation, temperature, elevation and precipitation are useful predictors of snail habitats which may be more reliable in assessing the distribution of schistosomiasis compared with prevalence survey data [158,329,330]. Environmental data can be obtained using remote sensing techniques (RS) and the geographic information system (GIS) [319,329,331,332]. A study in Ghana [333] utilised environmental variables including land surface temperatures (LST), normalized difference vegetation index (NDVI), and accumulated precipitation (AP) to analyse disease patterns with wide geographic coverage and varying levels of spatial and temporal aggregation. This assessment reported reduced rates of schistosomiasis, seasonal patterns across time zones and the associated schistosome infection rates, features that are useful in determining disease patterns [333].

Snail control plays a vital role in the interruption of schistosomiasis transmission [33,334-336]. Snail control using chemical molluscicides was introduced and used extensively in the 1950s-1970s in Africa, Asia and South America, until the inception of oral chemotherapeutics for humans led to its decline [32,337-339]. The most commonly used molluscicide is niclosamide, which is effective against all stages of the snail life cycle [32]. It has been shown to be effective in control and elimination programs for schistosomiasis in several African countries including Morocco [147]. The downside of niclosamide is that it can be toxic to the environment and other animals, expensive, labour intensive and does not prevent repopulation of snails after treatment $[34,35,147,340]$. Hence, an integrated control approach involving mass chemotherapy, snail control, improved access to portable water and sanitation, environmental modification, behaviourial changes and health education have been found to be more effective in schistosomiasis control that can lead to elimination [337,341,342]. This approach has led to transmission interruption and significant decline in disease prevalence in previously endemic areas in China. In Sub-Saharan Africa, the Zanzibar Elimination of Schistosomiasis Transmission (ZEST) project carried out betwen 2011-2017 using a combination of MDA, snail control (niclosamide) and behaviourial change measures, reported a significant decline in the prevalence of schistosomiasis and successfully eliminated the disease as a public health concern in most of its study sites [343]. It is worthy to note however, that transmission was not interrupted in these sites [343]. Another, a community-wide MDA and snail control program in rural Kenya reported significant declines in prevalence and intensity of the disease [344]. Alternative forms of snail control including introducing competitor snail or prawn species to feed on snail host populations should also be considered [150].

\subsubsection{Education and Knowledge}

As with most NTDs, poverty, lack of adequate infrastructure and a low level of education are important factors affecting the prevalence of schistosomiasis in Africa. The WHO has highlighted education as part of its strategic plan for schistosomiasis control in Africa along with MDA and WASH activities [98]. The lack of knowledge about schistosomiasis and how it is transmitted in endemic regions is a major risk factor and can prevent successful implementation of control programs, including MDA, in some areas. A qualitative formative study targeted at behaviourial change intervention in Zanzibar reported that people's knowledge of schistosomiasis symptoms, transmission and preven- 
tion was poor [345], despite previous control initiatives having been undertaken [346-348]. In Malawi during a MDA program in schools, children refused treatment as they were suspicious of the treatment with some scared of the large size or smell of the PZQ tablet, and because classmates felt dizzy after taking the drug [93]. There was also distrust in the community with some believing that the drug was a contraceptive, or they did not trust the medication in general. Others kept children home on treatment days as they considered schistosomiasis to be normal and could not understand the need for treatment [93]. After community education and involving the community in the MDA program, compliance went up, highlighting the need for community engagement in any control program. This suggests that regular school-based health education can play an important role on health behavior, and can aid in reducing infection prevalence among SAC [298].

An interactive board game, Schisto and Ladders ${ }^{\mathrm{TM}}$, which included information on the mode of schistosome transmission, behavioural risks associated with transmission, symptoms of infection and information on what to do to seek treatment, prevention of reinfection and control strategies for schistosomiasis was developed and tested in schools in an endemic area (near Abeokuta), in Nigeria [349]. By the end of the study, increase in knowledge of schistosomiasis and behavioural changes were observed among the participants [349]; as diagnostics were not included in the study, the impact of the intervention on disease prevalence in the area is unknown. In addition to increasing compliance in MDA [350], increased knowledge on transmission will help inform the community on how to prevent re-infection-an important aspect considering the current lack of a schistosomiasis vaccine.

A systematic review to understand knowledge, attitudes and practices (KAP) about schistosomiasis in a number of communities in sub-Saharan Africa identified several short comings [291]. The survey revealed there was exclusion of children under five, and therefore their caregivers, in education programs and there was a focus on SAC to the exclusion of other community members. This is generally due to greater ease in implementing education programs in schools and the belief that what children learn in school is reported back to and taken on board by their caregivers; however, this excludes a large portion of the community who do not have children. The review also showed gender disparity, with males more likely to have higher levels of knowledge of schistosomiasis, more likely to be exposed during fishing and farming and, possibly, more likely to be targeted by education programs, or having gained knowledge of the disease from other fishermen and farmers in the area.

Misconceptions are also a potential issue either from improperly understood education programs, or due to superstitious beliefs already present in the community [18]. Schistosomiasis as a sexually transmitted disease is a common misconception that can be a barrier to seeking treatment, particularly in women due to the associated stigma [18]. A study in Uganda reported that $78 \%$ of a study population of 370 SAC were aware of schistosomiasis but did not have an idea of its mode of transmission [351]. Most infections were likely to have come from lakes in the area and community-based education may have led to avoidance of high transmission areas, however lakes are the only water source available for the majority of the community. It is therefore important to pair education with health and hygiene infrastructure to provide options and access to safe drinking water, and the provision of toilets to increase sanitation and decrease environmental contamination with eggs. Several studies report that successful prevention programs among vulnerable groups, especially children, women and individuals whose occupations require contact with freshwater bodies could reduce the rate of transmission of schistosomiasis; and could eventually lead to reduced prevalence of the disease in the general population $[326,349,352]$.

\section{Factors That Determine the Distribution of Schistosomiasis in Africa}

As emphasized, schistosomiasis is a focal disease that requires the presence of the intermediate snail hosts. Various factors including climate change, flooding and manmade structures, particularly dams, can affect the habitats and spread of the infection by expand- 
ing snail habitats and increasing transmission these sites as well as introducing them to new locations [3].

\subsection{Climate Change}

Climatic conditions including temperature, precipitation and altitude are major factors that affect the distribution of Schistosoma species and are important to understand for control programs [353-355]. It has been reported that $S$. mansoni infections may increase in parts of eastern Africa as temperatures continue to rise, as it will influence the growth, survival and distribution of the parasite and its intermediate molluscan hosts [146,356-358]. It has also been noted, however, that infections may decrease in certain areas as increases in temperature may result in unfavourable conditions for both schistosomes and their snail hosts [146,356-358]. Pedersen et al. [359] reported a downward trend in schistosomiasis infections in Zimbabwe over three decades due to a warmer and drier climate, although MDA and behavioural changes may have also played a role in this downward trend [359,360]. A study in Ethiopia suggested that altitudes lower than $800 \mathrm{~m}$ above sea level favour the transmission of S. haematobium while altitudes between 1300 and $2000 \mathrm{~m}$ above sea level favour the transmission of S. mansoni [361]. An epidemiological survey of intestinal schistosomiasis in SAC living around the high altitude crater in Western Uganda reported that the geographic distribution of schistosomiasis may be altered due to increasing temperatures in tropical and sub-tropical regions [351]. The study suggested that altitudes above $1400 \mathrm{~m}$, which previously have shown no possibility of schistosomiasis transmission due to being too cold, were now experiencing transmission of the disease due to the increasing temperature resulting from climate change [351,362].

\subsection{Artificial (Man-Made) Activities}

Dams are crucial infrastructure in many ways including maintaining water availability and hydroelectric power production. However, construction of dams can lead to ecosystem imbalance, including negatively affecting the life cycle of natural schistosome intermediate snail host predators, such as Macrobrachium spp. river prawns, thereby leading to a rapid spread of schistosomiasis [363-365]. One example is the construction of the Diama Dam in Senegal that led to the introduction and spread of schistosomiasis in nearby villages [366,367]. Reproduction of river prawns, which normally fed on schistosome intermediate snail hosts, was affected as female prawns were prevented from migrating downstream while juvenile prawns were prevented from migrating upstream to complete their life cycle $[150,366,367]$. Restoring these river prawns to the area led to a decrease in schistosomiasis [150]. A study in Raffierkro, Côte d'Ivoire, during the construction and initial operation of a dam, showed low schistosomiasis levels but reported an increase in uninfected snail hosts as a result of the construction [368]. To date, however, there has been no follow-up report of the current status of the intermediate snail hosts and the level of schistosome transmission in this locality.

\subsection{Human Migration}

Several studies have reported an increased risk of schistosomiasis as a result of infected migrants moving from endemic regions. Forced displacement, rural-urban migration and refugee settlements are good examples of such migration. Studies among refugees and asylum seekers from sub-Saharan Africa reported a high number of urogenital schistosomiasis cases among migrant groups, which were mostly from West Africa [141,369]. Infected migrants most likely acquired the infection during childhood while resident in Africa [141,369]. Schistosomiasis has also been reported in seasonal migratory of workers who travel from uninfected areas to and from endemic areas, have frequent water contact and are faced with poor sanitary conditions [370]. Schistosomiasis is also diagnosed in returned travelers in non-endemic areas who visit endemic countries in Africa [371-374].

As referred to earlier, there have been some recently reported cases of S. haematobium in parts of Europe, including autochthonous infections in Corsica, France, likely intro- 
duced due to migration of African refuges [5,6,369,375-377]. Sustained transmission then occurred due to the presence of susceptible intermediate snail hosts. A case study from Spain identified S. haematobium in a patient originally from the Dominican Republic; the subject had no history of travel to schistosome-endemic areas, and was diagnosed based on the presence of haematuria, egg morphology, IHA and PCR [378]. The patient had experienced chronic symptoms since childhood, placing the likely source of infection as the Dominican Republic, where Lebanese immigrants may have inadvertently brought the infection in the 1980 's, indicating a potential infection lasting 30 years. However, Bulinus snails are known to be present in the South of Portugal, where the patient had previously travelled, and Planorbarius metidjensis occurs in Spain (which can transmit S. bovis) where the patient had swum in local watercourses, which may point to more recent infection within Europe. Another recent study identified six cases of S. haematobium in African migrants in the Canary Islands [369]. These infections were likely acquired in their endemic communities before migrating to Europe, although show a reasonable cause for transmission to non-endemic areas where viable intermediate hosts are present, such as has occurred in France $[369,375]$. Schistosomiasis has also been identified in long-term residents of Barcelona who migrated from endemic countries in sub-Saharan Africa. In 2002-2016, a study in Barcelona enrolled individuals into a study based on previous travel to schistosomiasis endemic countries and tested for schistosome infection by microscopy (urine and faecal), antibody detection, and/or radiological suspicion [379]. Schistosomiasis is often overlooked in initial health screening of refugees and immigrants from schistosomiasis-endemic areas, particularly as symptomology is often low in chronic infections, increasing time for diagnosis. In the Barcelona study, sixty-one individuals were identified infected with Schistosoma spp. and $90 \%$ of the study participants displayed symptoms of schistosomiasis including eosinophilia, haematuria and abdominal pain [379].

\section{COVID-19}

The world is currently plagued by the COVID-19 pandemic, one of the most serious health crisis in recent times. As of 1 April 2020, the WHO guidance to member states recommended postponement of community based surveys, active case-finding activities, and mass drug treatment (MDA) campaigns in NTD programmes in order to comply with public health measures for prevention of COVID-19 treatment [380]. However, the WHO did recommend continued support for patients presenting to health care facilities and continuance of essential vector control measures where possible [380]. It has been documented that individuals in many countries are reluctant to present to health care facilities for fear of contacting COVID-19, or to avoid adding to the workload of already stressed hospitals, and this is likely to be true in NTD endemic regions [381-384]. Furthermore, many health care personnel formerly engaged in NTD activities are likely to be now involved in COVID-19 responses, leaving aspects of NTD control and treatment nonoperational.

The COVID-19 pandemic incidence was initially lower than expected in Africa and in many other developing nations, but, towards the end of 2020, there was a rapid increase in the number of cases. Cases have continued to increase, especially in schistosomiasis and other NTD endemic areas [385]. This has resulted in the suspension of many MDA programs, leading inevitably to future outbreaks of schistosomiasis [386] and other NTDs [387]. Additionally, it has been suggested that interactions between the severe acute respiratory syndrome coronavirus 2 (SARS-CoV-2) and parasitic infections may result in increased viral susceptibility and more severe outcomes in patients to COVID-19 in NTD-endemic regions [388].

\section{Conclusions}

Schistosomiasis continues to be a major public health issue in Africa, although the paucity of epidemiological studies in many African countries prevents full understanding of the disease in many settings and hinders control and elimination efforts. Effective health policies and surveillance, improved hygiene and sanitary conditions, as well as increased 
education and knowledge have led to the control and transmission interruption of the disease in some parts of Africa with assistance from government and commerical agencies.

The WHO has released a new 2021-2030 roadmap for NTDs. Among the recommendations, children should be the first target group for schistosomiasis intervention due to the adverse effects the disease has on their growth and development [174], and integration of health education that is community-wide, not just aimed at SAC, is essential. Additionally, early, accurate diagnosis and treatment in children reduces heavy infections and this will decrease the risk of severe disease and disability in juveniles [389]. Pre-SAC, women and adolescent girls are severely affected by the disease and there is a need to target and include them in public health interventions. More insight and understanding of religious, social, environmental and economic factors among children and adults alike, can assist in health intervention strategies directed at disadvantaged communities, as well as involving targeted communities in developing interventions. By involving these communities, uptake and longevity of programs can be increased. Having communities involved from early stages will also lead to 'demystification' around infection-something that may be particularly useful for alleviating stigma surrounding female infections, as well as around other cultural and societal norms that can prevent uptake of treatment.

Risk mapping is also emphasised as it is crucial to prioritise areas for targeted intervention and for surveillance after transmission interruption. Combined with environmental monitoring, risk mapping can give accurate predictions for outbreaks and modelling can incorporate flooding events which may increase risks of schistosomiasis infection as well as increasing snail dispersal. Countries in Africa are at many different stages of control; some are at very early stages while others are nearing transmission interruption. Therefore, different approaches will be required depending on status. Risk mapping may be the first step for many countries on the journey towards control and elimination of schistosomiasis, as it could allow for more targeted MDA in at-risk areas where geographical prevalence information may be lacking. On the other hand, environmental and snail monitoring may be of more use in countries approaching transmission interruption to determine risk levels and monitor for outbreaks or 'rebounding' infection.

Overall there is a need for current, up to date, information of the prevalence and geographical spread of schistosomiasis to help inform control programs. Multifaceted control that includes snail monitoring and control, health education, and increases in public health infrastructure combined with widespread chemotherapy, as well as poverty alleviation, will be critically important to reach the goal of eventually eliminating schistosomiasis from Africa.

Author Contributions: O.P.A.: Writing-first draft, review and editing, data collection, tables, figures. D.P.M.: Writing-review and editing, project administration, supervision. M.K.J.: Writing-review and editing. C.A.G.: Writing-review and editing, supervision, project administration. All authors have read and agreed to the published version of the manuscript.

Funding: This research received no external funding.

Institutional Review Board Statement: Not applicable.

Informed Consent Statement: Not applicable.

Data Availability Statement: Data sharing not applicable. No new data were created or analysed in this study. Data sharing is not applicable to this article.

Acknowledgments: The authors would like to thank Madeleine Flynn from the Communications and Marketing Department at the QIMR Berghofer Medical Research Institute for her assistance in producing the figures used in this manuscript.

Conflicts of Interest: The authors declare no conflict of interest. 


\section{References}

1. WHO. Schistosomiasis. 2018. Available online: https://www.who.int/news-room/fact-sheets/detail/schistosomiasis (accessed on 1 March 2019).

2. $\quad$ van der Werf, M.J.; de Vlas, S.J.; Brooker, S.; Looman, C.W.; Nagelkerke, N.J.; Habbema, J.D.; Engels, D. Quantification of clinical morbidity associated with schistosome infection in sub-Saharan Africa. Acta Trop. 2003, 86, 125-139. [CrossRef]

3. McManus, D.P.; Dunne, D.W.; Sacko, M.; Utzinger, J.; Vennervald, B.J.; Zhou, X.N. Schistosomiasis. Nat. Rev. Dis. Primers 2018, 4, 13. [CrossRef] [PubMed]

4. Gryseels, B.; Polman, K.; Clerinx, J.; Kestens, L. Human schistosomiasis. Lancet 2006, 368, 1106-1118. [CrossRef]

5. Boissier, J.; Grech-Angelini, S.; Webster, B.L.; Allienne, J.F.; Huyse, T.; Mas-Coma, S.; Toulza, E.; Barre-Cardi, H.; Rollinson, D.; Kincaid-Smith, J.; et al. Outbreak of urogenital schistosomiasis in Corsica (France): An epidemiological case study. Lancet Infect. Dis. 2016, 16, 971-979. [CrossRef]

6. Boissier, J.; Mone, H.; Mitta, G.; Bargues, M.D.; Molyneux, D.; Mas-Coma, S. Schistosomiasis reaches Europe. Lancet Infect. Dis. 2015, 15, 757-758. [CrossRef]

7. Stothard, J.R.; Sekeleghe, A.K.; Mohammad, H.A.-H.; Janelisa, M.; Bonnie, L.W. Future schistosome hybridizations: Will all Schistosoma haematobium hybrids please stand-up. PLoS Negl. Trop. Dis. 2020, 14, e0008201. [CrossRef]

8. Webster, B.L.; Diaw, O.T.; Seye, M.M.; Webster, J.P.; Rollinson, D. Introgressive hybridization of Schistosoma haematobium group species in Senegal: Species barrier break down between ruminant and human schistosomes. PLoS Negl. Trop. Dis. 2013, 7, e2110. [CrossRef]

9. Webster, B.L. On the Interactions of Schistosoma Haematobium, S. Guineensis and Their Hybrids in the Laboratory and in the Field; University College London: London, UK, 2003.

10. Kabatereine, N.B.; Vennervald, B.J.; Ouma, J.H.; Kemijumbi, J.; Butterworth, A.E.; Dunne, D.W.; Fulford, A.J. Adult resistance to schistosomiasis mansoni: Age-dependence of reinfection remains constant in communities with diverse exposure patterns. Parasitology 1999, 118, 101-105. [CrossRef] [PubMed]

11. Steinmann, P.; Keiser, J.; Bos, R.; Tanner, M.; Utzinger, J. Schistosomiasis and water resources development: Systematic review, meta-analysis, and estimates of people at risk. Lancet Infect. Dis. 2006, 6, 411-425. [CrossRef]

12. De Bont, J.; Vercruysse, J. Schistosomiasis in Cattle. Adv. Parasitol. 1998, 41, 285-364. [CrossRef]

13. Charlier, J.; van der Voort, M.; Kenyon, F.; Skuce, P.; Vercruysse, J. Chasing helminths and their economic impact on farmed ruminants. Trends Parasitol. 2014, 30, 361-367. [CrossRef]

14. You, H.; Cai, P.; Tebeje, B.M.; Li, Y.; McManus, D.P. Schistosome Vaccines for Domestic Animals. Trop. Med. Infect. Dis. 2018, 3 , 68. [CrossRef]

15. Vercruysse, J. Schistosomiasis. Available online: https://www.msdvetmanual.com/circulatory-system/blood-parasites/ schistosomiasis (accessed on 26 May 2021).

16. Hotez, P.J.; Fenwick, A.; Savioli, L.; Molyneux, D.H. Rescuing the bottom billion through control of neglected tropical diseases. Lancet 2009, 373, 1570-1575. [CrossRef]

17. Hotez, P.J.; Fenwick, A. Schistosomiasis in Africa: An emerging tragedy in our new global health decade. PLoS Negl. Trop. Dis. 2009, 3, e485. [CrossRef]

18. Lothe, A.; Zulu, N.; Øyhus, A.O.; Kjetland, E.F.; Taylor, M. Treating schistosomiasis among South African high school pupils in an endemic area, a qualitative study. BMC Infect. Dis. 2018, 18, 239. [CrossRef]

19. Tuhebwe, D.; Bagonza, J.; Kiracho, E.E.; Yeka, A.; Elliott, A.M.; Nuwaha, F. Uptake of mass drug administration programme for schistosomiasis control in Koome Islands, Central Uganda. PLoS ONE 2015, 10, e0123673. [CrossRef]

20. Akogun, O.B. Urinary schistosomiasis and the coming of age in Nigeria. Parasitol. Today 1991, 7, 62. [CrossRef]

21. Boko, P.M.; Ibikounle, M.; Onzo-Aboki, A.; Tougoue, J.-J.; Sissinto, Y.; Batcho, W.; Kinde-Gazard, D.; Kabore, A. Schistosomiasis and soil transmitted helminths distribution in Benin: A baseline prevalence survey in 30 districts. PLoS ONE 2016, 11, e0162798. [CrossRef] [PubMed]

22. WHO. Ending the Neglect to Attain the Sustainable Development Goals-A Road Map for Neglected Tropical Diseases 2021-2030; World Health Organization: Geneva, Swizterland, 2020.

23. WHO. Accelerating Work to Overcome the Global Impact of Neglected Tropical Diseases: A Roadmap for Implementation. 2012 Available online: https:/ /apps.who.int/iris/handle/10665/70809 (accessed on 7 March 2019).

24. Kajihara, N.; Hirayama, K. The War against a Regional Disease in Japan A History of the Eradication of Schistosomiasis japonica. Trop. Med. Health 2011, 39 (Suppl. S1), 3-44.

25. Hotez, P.J.; Kamath, A. Neglected tropical diseases in sub-saharan Africa: Review of their prevalence, distribution, and disease burden. PLoS Negl. Trop. Dis. 2009, 3, e412. [CrossRef] [PubMed]

26. Bergquist, R.; Zhou, X.-N.; Rollinson, D.; Reinhard-Rupp, J.; Klohe, K. Elimination of schistosomiasis: The tools required. Infect. Dis. Poverty 2017, 6, 158. [CrossRef]

27. Tchuem Tchuenté, L.-A.; Rollinson, D.; Stothard, J.; Molyneux, D. Moving from control to elimination of schistosomiasis in sub-Saharan Africa: Time to change and adapt strategies. Infect. Dis. Poverty 2017, 6, 42. [CrossRef]

28. Butterworth, A.E. Human immunity to schistosomes: Some questions. Parasitol. Today 1994, 10, 378-380. [CrossRef]

29. Butterworth, A.E.; Curry, A.J.; Dunne, D.W.; Fulford, A.J.; Kimani, G.; Kariuki, H.C.; Klumpp, R.; Koech, D.; Mbugua, G.; Ouma, J.H.; et al. Immunity and morbidity in human schistosomiasis mansoni. Trop. Geogr. Med. 1994, 46, 197-208. 
30. Colley, D.G.; Bustinduy, A.L.; Secor, W.E.; King, C.H. Human schistosomiasis. Lancet 2014, 383, 2253-2264. [CrossRef]

31. Chabasse, D.; Bertrand, G.; Leroux, J.P.; Gauthey, N.; Hocquet, P. Developmental bilharziasis caused by Schistosoma mansoni discovered 37 years after infestation. Bull. Soc. Pathol. Exot. Fil. 1985, 78, 643-647.

32. McCullough, F.S.; Gayral, P.; Duncan, J.; Christie, J.D. Molluscicides in schistosomiasis control. Bull. World Health Organ. 1980, $58,681-689$.

33. WHO. Field Use of Molluscicides in Schistosomiasis Control Programmes: An Operational Manual for Programme Managers; WHO: Geneva, Swizterland, 2017.

34. Ekabo, O.A.; Farnsworth, N.R.; Henderson, T.O.; Mao, G.; Mukherjee, R. Antifungal and molluscicidal saponins from Serjania salzmanniana. J. Nat. Prod. 1996, 59, 431-435. [CrossRef]

35. Rocha-Filho, C.A.; Albuquerque, L.P.; Silva, L.R.; Silva, P.C.; Coelho, L.C.; Navarro, D.M.; Albuquerque, M.C.; Melo, A.M.; Napoleão, T.H.; Pontual, E.V.; et al. Assessment aof toxicity of Moringa oleifera flower extract to Biomphalaria glabrata, Schistosoma mansoni and Artemia salina. Chemosphere 2015, 132, 188-192. [CrossRef] [PubMed]

36. Gray, D.; Ross, A.; Li, Y.-S.; McManus, D. Diagnosis and management of schistosomiasis. Br. Med. J. 2011, $342,1138$. [CrossRef] [PubMed]

37. Ross, A.G.; Vickers, D.; Olds, G.R.; Shah, S.M.; McManus, D.P. Katayama syndrome. Lancet Infect. Dis. 2007, 7, 218-224. [CrossRef]

38. Ross, A.G.P.; Bartley, P.B.; Sleigh, A.C.; Olds, G.R.; Li, Y.; Williams, G.M.; McManus, D.P. Schistosomiasis. N. Engl. J. Med. 2002, 346, 1212-1220. [CrossRef] [PubMed]

39. Ross, A.G.; McManus, D.P.; Farrar, J.; Hunstman, R.J.; Gray, D.J.; Li, Y.S. Neuroschistosomiasis. J. Neurol. 2012, 259 , 22-32. [CrossRef] [PubMed]

40. Gunn, A.; Pitt, S.J. Parasitology an Integrated Approach; John Wiley \& Sons: Chichester, UK, 2012.

41. Wynn, T.A.; Thompson, R.W.; Cheever, A.W.; Mentink-Kane, M.M. Immunopathogenesis of schistosomiasis. Immunol Rev. 2004, 201, 156-167. [CrossRef]

42. Burke, M.L.; Jones, M.K.; Gobert, G.N.; Li, Y.S.; Ellis, M.K.; McManus, D.P. Immunopathogenesis of human schistosomiasis. Parasite Immunol. 2009, 31, 163-176. [CrossRef]

43. Costain, A.H.; MacDonald, A.S.; Smits, H.H. Schistosome egg migration: Mechanisms, pathogenesis and host immune responses. Front. Immunol. 2018, 9, 3042. [CrossRef]

44. Almeda, J.; Corachan, M.; Sousa, A.; Ascaso, C.; Carvalho, J.M.; Rollinson, D.; Southgate, V.R. Schistosomiasis in the Republic of São Tomé and Principe: Human studies. Trans. R. Soc. Trop. Med. Hyg. 1994, 88, 406-409. [CrossRef]

45. Poggensee, G.; Feldmeier, H.; Krantz, I. Schistosomiasis of the female genital tract: Public health aspects. Parasitol. Today 1999, 15, 378-381. [CrossRef]

46. Christinet, V.; Lazdins-Helds, J.K.; Stothard, J.R.; Reinhard-Rupp, J. Female genital schistosomiasis (FGS): From case reports to a call for concerted action against this neglected gynaecological disease. Int. J. Parasitol. 2016, 46, 395-404. [CrossRef] [PubMed]

47. Nour, N.M. Schistosomiasis: Health effects on women. Rev. Obstet. Gynecol. 2010, 3, 28-32. [PubMed]

48. Friedman, J.F.; Mital, P.; Kanzaria, H.K.; Olds, G.R.; Kurtis, J.D. Schistosomiasis and pregnancy. Trends Parasitol. 2007, $23,159-164$. [CrossRef] [PubMed]

49. Helling-Giese, G.; Kjetland, E.F.; Gundersen, S.G.; Poggensee, G.; Richter, J.; Krantz, I.; Feldmeier, H. Schistosomiasis in women: Manifestations in the upper reproductive tract. Acta Trop. 1996, 62, 225-238. [CrossRef]

50. Ajanga, A.; Lwambo, N.J.; Blair, L.; Nyandindi, U.; Fenwick, A.; Brooker, S. Schistosoma mansoni in pregnancy and associations with anaemia in Northwest Tanzania. Trans. R. Soc. Trop. Med. Hyg. 2006, 100, 59-63. [CrossRef]

51. Ben-Chetrit, E.; Lachish, T.; Mørch, K.; Atias, D.; Maguire, C.; Schwartz, E. Schistosomiasis in pregnant travelers: A case series. J. Travel Med. 2015, 22, 94-98. [CrossRef]

52. Downs, J.A.; Dupnik, K.M.; van Dam, G.J.; Urassa, M.; Lutonja, P.; Kornelis, D.; de Dood, C.J.; Hoekstra, P.; Kanjala, C.; Isingo, R.; et al. Effects of schistosomiasis on susceptibility to HIV-1 infection and HIV-1 viral load at HIV-1 seroconversion: A nested case-control study. PLoS Negl. Trop. Dis. 2017, 11, e0005968. [CrossRef] [PubMed]

53. Kjetland, E.F.; Leutscher, P.D.C.; Ndhlovu, P.D. A review of female genital schistosomiasis. Trends Parasitol. 2012, 28, 58-65. [CrossRef] [PubMed]

54. Kjetland, E.F.; Ndhlovu, P.D.; Gomo, E.; Mduluza, T.; Midzi, N.; Gwanzura, L.; Mason, P.R.; Sandvik, L.; Friis, H.; Gundersen, S.G. Association between genital schistosomiasis and HIV in rural Zimbabwean women. Aids 2006, 20, 593-600. [CrossRef]

55. Olusegun, A.F.; Ehis, O.C.; Richard, O. Proportion of urinary schistosomiasis among HIV-infected subjects in Benin City, Nigeria. Oman Med. J. 2011, 26, 175-177. [CrossRef]

56. Downs, J.A.; Mguta, C.; Kaatano, G.M.; Mitchell, K.B.; Bang, H.; Simplice, H.; Kalluvya, S.E.; Changalucha, J.M.; Johnson, W.D., Jr.; Fitzgerald, D.W. Urogenital schistosomiasis in women of reproductive age in Tanzania's Lake Victoria region. Am. J. Trop. Med. Hyg. 2011, 84, 364-369. [CrossRef]

57. Feldmeier, H.; Krantz, I.; Poggensee, G. Female genital schistosomiasis as a risk-factor for the transmission of HIV. Int. J. STD AIDS 1994, 5, 368-372. [CrossRef]

58. Ndhlovu, P.D.; Mduluza, T.; Kjetland, E.F.; Midzi, N.; Nyanga, L.; Gundersen, S.G.; Friis, H.; Gomo, E. Prevalence of urinary schistosomiasis and HIV in females living in a rural community of Zimbabwe: Does age matter? Trans. R. Soc. Trop Med. Hyg. 2007, 101, 433-438. [CrossRef] [PubMed] 
59. Leutscher, P.; Ramarokoto, C.E.; Reimert, C.; Feldmeier, H.; Esterre, P.; Vennervald, B.J. Community-based study of genital schistosomiasis in men from Madagascar. Lancet 2000, 355, 117-118. [CrossRef]

60. Wall, K.M.; Kilembe, W.; Vwalika, B.; Dinh, C.; Livingston, P.; Lee, Y.M.; Lakhi, S.; Boeras, D.; Naw, H.K.; Brill, I.; et al. Schistosomiasis is associated with incident HIV transmission and death in Zambia. PLoS Negl. Trop. Dis. 2018, 12, e0006902. [CrossRef] [PubMed]

61. Mbabazi, P.S.; Andan, O.; Fitzgerald, D.W.; Chitsulo, L.; Engels, D.; Downs, J.A. Examining the relationship between urogenital schistosomiasis and HIV infection. PLoS Negl. Trop. Dis. 2011, 5, e1396. [CrossRef] [PubMed]

62. Kjetland, E.F.; Hegertun, I.E.; Baay, M.F.; Onsrud, M.; Ndhlovu, P.D.; Taylor, M. Genital schistosomiasis and its unacknowledged role on HIV transmission in the STD intervention studies. Int. J. STD AIDS 2014, 25, 705-715. [CrossRef] [PubMed]

63. Zegers-Hochschild, F.; Adamson, G.D.; de Mouzon, J.; Ishihara, O.; Mansour, R.; Nygren, K.; Sullivan, E.; Vanderpoel, S. International Committee for Monitoring Assisted Reproductive Technology (ICMART) and the World Health Organization (WHO) revised glossary of ART terminology, 2009. Fertil. Steril. 2009, 92, 1520-1524. [CrossRef]

64. Bentefouet, T.L.; Thiam, M.; Gaye, A.M.; El Wardi, A.; Gueye, L.; Cisse, M.L. Case report of tubo-ovarian Bilharziasis presented with pelvic pain and secondary infertility. Case Rep. Images Obstet. Gynecol. 2017, 3, 19-22. [CrossRef]

65. Ogunniyi, S.O.; Nganwuchu, A.M.; Adenle, M.A.; Dare, F.O. Pregnancy following infertility due to pelvic schistosomiasis-A case report. West. Afr. J. Med. 1994, 13, 132-133.

66. Aminu, M.B.; Abdullahi, K.; Dattijo, L.M. Tubal ectopic gestation associated with genital schistosomiasis: A case report. Afr. J. Reprod. Health La Rev. Afr. de la St. Reprod. 2014, 18, 144-146.

67. Okonofua, F.E.; Ojo, O.S.; Odunsi, O.A.; Odesanmi, W.O. Ectopic pregnancy associated with tubal schistosomiasis in a Nigerian woman. Int. J. Gynaecol. Obstet. 1990, 32, 281-284. [CrossRef]

68. Woodall, P.A.; Kramer, M.R. Schistosomiasis and infertility in East Africa. Am. J. Trop. Med. Hyg. 2018, 98, 1137-1144. [CrossRef] [PubMed]

69. Kini, S.; Dayoub, N.; Raja, A.; Pickering, S.; Thong, J. Schistosomiasis-induced male infertility. BMJ Case Rep. 2009, 2009. [CrossRef]

70. Adisa, J.; Egbujo, E.M.; Yahaya, B.A.; Echejoh, G. Primary infertility associated with Schistosoma mansoni: A case report from the Jos plateau, North-Central Nigeria. Afr. Health Sci. 2012, 12, 563-565. [PubMed]

71. Madden, F. Two rare manifestations of bilharziosis. Lancet 1911, 178, 754-755. [CrossRef]

72. Leutscher, P.D.; Ramarokoto, C.E.; Hoffmann, S.; Jensen, J.S.; Ramaniraka, V.; Randrianasolo, B.; Raharisolo, C.; Migliani, R.; Christensen, N. Coexistence of urogenital schistosomiasis and sexually transmitted infection in women and men living in an area where Schistosoma haematobium is endemic. Clin. Infect. Dis. 2008, 47, 775-782. [CrossRef]

73. Kayuni, S.; Lampiao, F.; Makaula, P.; Juziwelo, L.; Lacourse, E.J.; Reinhard-Rupp, J.; Leutscher, P.D.C.; Stothard, J.R. A systematic review with epidemiological update of male genital schistosomiasis (MGS): A call for integrated case management across the health system in sub-Saharan Africa. Parasite Epidemiol. Control. 2018, 4, e00077. [CrossRef]

74. Gelfand, M.; Ross, C.M.; Blair, D.M.; Castle, W.M.; Weber, M.C. Schistosomiasis of the male pelvic organs. Severity of infection as determined by digestion of tissue and histologic methods in 300 cadavers. Am. J. Trop. Med. Hyg. 1970, 19, 779-784. [CrossRef] [PubMed]

75. Vilana, R.; Corachan, M.; Gascon, J.; Valls, E.; Bru, C. Schistosomiasis of the male genital tract: Transrectal sonographic findings. J. Urol. 1997, 158, 1491-1493. [CrossRef]

76. Kayuni, S.A.; Lacourse, E.J.; Makaula, P.; Lampiao, F.; Juziwelo, L.; Fawcett, J.; Shaw, A.; Alharbi, M.H.; Verweij, J.J.; Stothard, J.R. Case report: Highlighting male genital schistosomiasis (MGS) in fishermen from the southwestern shoreline of Lake Malawi, Mangochi District. Am. J. Trop. Med. Hyg. 2019, 101, 1331. [CrossRef]

77. Abol-Enein, H. Infection: Is it a cause of bladder cancer? Scand. J. Urol. Nephrol. Suppl. 2008, 79-84. [CrossRef]

78. Heyns, C.F.; van der Merwe, A. Bladder cancer in Africa. Can. J. Urol. 2008, 15, 3899-3908. [PubMed]

79. Shiff, C.; Veltri, R.; Naples, J.; Quartey, J.; Otchere, J.; Anyan, W.; Marlow, C.; Wiredu, E.; Adjei, A.; Brakohiapa, E.; et al. Ultrasound verification of bladder damage is associated with known biomarkers of bladder cancer in adults chronically infected with Schistosoma haematobium in Ghana. Trans. R. Soc. Trop. Med. Hyg. 2006, 100, 847-854. [CrossRef]

80. Michaud, D.S. Chronic inflammation and bladder cancer. Urol. Oncol. Semin. Orig. Investig. 2007, 25, 260-268. [CrossRef]

81. El-Bolkainy, M.N.; Mokhtar, N.M.; Ghoneim, M.A.; Hussein, M.H. The impact of schistosomiasis on the pathology of bladder carcinoma. Cancer 1981, 48, 2643-2648. [CrossRef]

82. Kitinya, J.N.; Laurèn, P.A.; Eshleman, L.J.; Paljärvi, L.; Tanaka, K. The incidence of squamous and transitional cell carcinomas of the urinary bladder in northern Tanzania in areas of high and low levels of endemic Schistosoma haematobium infection. Trans. R. Soc. Trop. Med. Hyg. 1986, 80, 935-939. [CrossRef]

83. Botelho, M.C.; Figueiredo, J.; Alves, H. Bladder cancer and urinary schistosomiasis in Angola. J. Nephrol. Res. 2015, 1, 22-24. [CrossRef]

84. Gouda, I.; Mokhtar, N.; Bilal, D.; El-Bolkainy, T.; El-Bolkainy, N.M. Bilharziasis and bladder cancer: A time trend analysis of 9843 patients. J. Egypt. Natl. Cancer Inst. 2007, 19, 158-162.

85. Botelho, M.C.; Machado, J.; Da Costa, J. Schistosoma haematobium total antigen induces increased proliferation, migration and invasion, and decreases apoptosis of normal epithelial cells. Virulence 2010, 1, 84-87. [CrossRef]

86. Vennervald, B.J.; Polman, K. Helminths and malignancy. Parasite Immunol. 2009, 31, 686-696. [CrossRef] [PubMed] 
87. Botelho, M.; Oliveira, P.; Gomes, J.; Gartner, F.; Lopes, C.; da Costa, J.M.C.; Machado, J.C. Tumourigenic effect of Schistosoma haematobium total antigen in mammalian cells. Int. J. Exp. Pathol. 2009, 90, 448-453. [CrossRef]

88. Doenhoff, M.J.; Cioli, D.; Utzinger, J. Praziquantel: Mechanisms of action, resistance and new derivatives for schistosomiasis. Curr. Opin. Infect. Dis. 2008, 21, 659-667. [CrossRef]

89. Cioli, D.; Pica-Mattoccia, L. Praziquantel. Parasitol Res. 2003, 90 (Suppl. S1), S3-S9. [CrossRef]

90. Utzinger, J.; Xiao, S.H.; Tanner, M.; Keiser, J. Artemisinins for schistosomiasis and beyond. Curr. Opin. Investig. Drugs 2007, $8,105-116$.

91. Harries, A.D.; Cook, G.C. Acute schistosomiasis (Katayama fever): Clinical deterioration after chemotherapy. J. Infect. 1987, 14, 159-161. [CrossRef]

92. WHO. Preventive Chemotherapy in Human Helminthiasis: Coordinated Use of Anthelminthic Drugs in Control Interventions: A Manual for Health Professionals and Programme Managers. Schistosomiasis, A Major Public Health Problem. 2015. Available online: http:/ / www.who.int/schistosomiasis/en/. (accessed on 22 March 2019).

93. WHO. Helminth Control in School Age Children A Guide for Control Managers Second Edition; World Heal Organisation: Geneva, Switzerland, 2011.

94. WHO. Summary of global update on implementation of preventive chemotherapy against neglected tropical diseases in 2019/Resume des donnees mondiales actualisees sur la mise en oeuvre de la chimioprevention contre les maladies tropicales negligees en 2019. Wkly. Epidemiol. Rec. 2020, 95, 469.

95. Cioli, D.; Pica-Mattoccia, L.; Basso, A.; Guidi, A. Schistosomiasis control: Praziquantel forever? Mol. Biochem. Parasitol. 2014, 195, 23-29. [CrossRef]

96. Prüss-Üstün, A.; Bos, R.; Gore, F.; Bartram, J. Safer Water, Better Health: Costs, Benefits and Sustainability of Interventions to Protect and Promote Health; World Health Organization: Geneva, Swizterland, 2008; p. 60.

97. WHO. Neglected Tropical Diseases, Hidden Successes, Emerging Opportunities; World Health Organization: Geneva, Swizterland; 52p.

98. WHO. Regional Strategic Plan for Neglected Tropical Diseases in the African Region 2014-2020; World Health Organization Regional Office for Africa: Brazzaville, Cango, 2013.

99. Campbell, S.J.; Savage, G.B.; Gray, D.J.; Atkinson, J.A.; Soares Magalhães, R.J.; Nery, S.V.; McCarthy, J.S.; Velleman, Y.; Wicken, J.H.; Traub, R.J.; et al. Water, Sanitation, and Hygiene (WASH): A critical component for sustainable soil-transmitted helminth and schistosomiasis control. PLoS Negl. Trop. Dis. 2014, 8, e2651. [CrossRef]

100. Alsallaq, R.A.; Gurarie, D.; Ndeffo Mbah, M.; Galvani, A.; King, C. Quantitative assessment of the impact of partially protective anti-schistosomiasis vaccines. PLoS Negl. Trop. Dis. 2017, 11, e0005544. [CrossRef]

101. Tebeje, B.M.; Harvie, M.; You, H.; Loukas, A.; McManus, D.P. Schistosomiasis vaccines: Where do we stand? Parasites Vectors 2016, 9, 528. [CrossRef]

102. Mulero, S.; Rey, O.; Arancibia, N.; Mas-Coma, S.; Boissier, J. Persistent establishment of a tropical disease in Europe: The preadaptation of schistosomes to overwinter. Parasites Vectors 2019, 12, 379. [CrossRef]

103. Dazo, B.C.; Biles, J.E. Two new field techniques for detection and counting of Schistosoma haematobium eggs in urine samples, with an evaluation of both methods. Bull. World Health Organ. 1974, 51, 399-408.

104. Teesdale, C.H.; Amin, M.A. A simple thick smear technique for the diagnosis of Schistosoma mansoni infection. Bull. World Health Organ. 1976, 54, 703-705.

105. Lunde, M.N.; Ottesen, E.A. Enzyme-linked immunosorbent assay (ELISA) for detecting IgM and IgE antibodies in human schistosomiasis. Am. J. Trop Med. Hyg. 1980, 29, 82-85. [CrossRef] [PubMed]

106. Wen, L.Y.; Chen, J.H.; Ding, J.Z.; Zhang, J.F.; Lu, S.H.; Yu, L.L.; Shen, L.Y.; Wu, G.L.; Zhou, X.N.; Zheng, J. Evaluation on the applied value of the dot immunogold filtration assay (DIGFA) for rapid detection of anti-Schistosoma japonicum antibody. Acta Trop. 2005, 96, 142-147. [CrossRef] [PubMed]

107. Sarhan, R.M.; Aminou, H.A.; Saad, G.A.; Ahmed, O.A. Comparative analysis of the diagnostic performance of adult, cercarial and egg antigens assessed by ELISA, in the diagnosis of chronic human Schistosoma mansoni infection. Parasitol Res. 2014, 113, 3467-3476. [CrossRef]

108. Corstjens, P.L.; De Dood, C.J.; Kornelis, D.; Fat, E.M.; Wilson, R.A.; Kariuki, T.M.; Nyakundi, R.K.; Loverde, P.T.; Abrams, W.R.; Tanke, H.J.; et al. Tools for diagnosis, monitoring and screening of Schistosoma infections utilizing lateral-flow based assays and upconverting phosphor labels. Parasitology 2014, 141, 1841-1855. [CrossRef] [PubMed]

109. Coulibaly, J.T.; Knopp, S.; N'Guessan, N.A.; Silué, K.D.; Fürst, T.; Lohourignon, L.K.; Brou, J.K.; N’Gbesso, Y.K.; Vounatsou, P.; N'Goran, E.K.; et al. Accuracy of Urine Circulating Cathodic Antigen (CCA) Test for Schistosoma mansoni Diagnosis in Different Settings of Côte d'Ivoire. PLoS Negl. Trop. Dis. 2011, 5, e1384. [CrossRef]

110. Tchuem Tchuenté, L.-A.; Kueté Fouodo, C.J.; Kamwa Ngassam, R.I.; Sumo, L.; Dongmo Noumedem, C.; Kenfack, C.M.; Gipwe, N.F.; Nana, E.D.; Stothard, J.R.; Rollinson, D. Evaluation of Circulating Cathodic Antigen (CCA) Urine-Tests for Diagnosis of Schistosoma mansoni Infection in Cameroon. PLoS Negl. Trop. Dis. 2012, 6, e1758. [CrossRef]

111. Abdel-Fattah, M.; Al-Sherbiny, M.; Osman, A.; Charmy, R.; Tsang, V. Improving the detection limit of quantitative diagnosis of anti-S. haematobium antibodies using Falcon Assay Screening Test (FAST) ELISA by developing a new standard curve. Parasitol. Res. 2011, 108, 1457-1463. [CrossRef] [PubMed]

112. Gobert, G.N.; Chai, M.; Duke, M.; McManus, D.P. Copro-PCR based detection of Schistosoma eggs using mitochondrial DNA markers. Mol. Cell. Probes 2005, 19, 250-254. [CrossRef] 
113. Lier, T.; Simonsen, T.; Haaheim, T.; Hjelmevoll, T.; Vennervald, T.; Johansen, T. Novel real-time PCR for detection of Schistosoma japonicum in stool. Southeast Asian J. Trop. Med. Public Health 2006, 37, 257-264.

114. Pontes, L.; Dias-Neto, E.; Rabello, A. Detection by polymerase chain reaction of Schistosoma mansoni DNA in human serum and feces. Am. J. Trop. Med. Hyg. 2002, 66, 157-162. [CrossRef]

115. Sandoval, N.; Siles-Lucas, M.; Aban, J.L.; Pérez-Arellano, J.L.; Gárate, T.; Muro, A. Schistosoma mansoni: A diagnostic approach to detect acute schistosomiasis infection in a murine model by PCR. Exp. Parasitol. 2006, 114, 84-88. [CrossRef]

116. Sandoval, N.; Siles-Lucas, M.; Pérez-Arellano, J.L.; Carranza, C.; Puente, S.; López-Abán, J.; Muro, A. A new PCR-based approach for the specific amplification of DNA from different Schistosoma species applicable to human urine samples. Parasitology 2006, 133, 581-587. [CrossRef]

117. Suzuki, T.; Osada, Y.; Kumagai, T.; Hamada, A.; Okuzawa, E.; Kanazawa, T. Early detection of Schistosoma mansoni infection by touchdown PCR in a mouse model. Parasitol. Int. 2006, 55, 213-218. [CrossRef]

118. Weerakoon, K.G.; Gordon, C.A.; Williams, G.M.; Cai, P.; Gobert, G.N.; Olveda, R.M.; Ross, A.G.; Olveda, D.U.; McManus, D.P. Droplet digital PCR diagnosis of human schistosomiasis: Parasite cell-free DNA detection in diverse clinical samples. J. Infect. Dis. 2017, 216, 1611-1622. [CrossRef]

119. Weerakoon, K.G.; Gordon, C.A.; Cai, P.; Gobert, G.N.; Duke, M.; Williams, G.M.; McManus, D.P. A novel duplex ddPCR assay for the diagnosis of schistosomiasis japonica: Proof of concept in an experimental mouse model. Parasitology 2017, 144, 1005-1015. [CrossRef]

120. Notomi, T.; Okayama, H.; Masubuchi, H.; Yonekawa, T.; Watanabe, K.; Amino, N.; Hase, T. Loop-mediated isothermal amplification of DNA. Nucleic Acids Res. 2000, 28, E63. [CrossRef]

121. Xu, J.; Guan, Z.-X.; Zhao, B.; Wang, Y.-Y.; Cao, Y.; Zhang, H.-Q.; Zhu, X.-Q.; He, Y.-K.; Xia, C.-M. DNA detection of Schistosoma japonicum: Diagnostic validity of a lamp assay for low-intensity infection and effects of chemotherapy in humans (diagnostic validity of lamp in humans). PLoS Negl. Trop. Dis. 2015, 9, e0003668. [CrossRef]

122. Qin, Z.-Q.; Xu, J.; Feng, T.; Lv, S.; Qian, Y.-J.; Zhang, L.-J.; Li, Y.-L.; Lv, C.; Bergquist, R.; Li, S.-Z.; et al. Field Evaluation of a Loop-Mediated Isothermal Amplification (LAMP) Platform for the Detection of Schistosoma japonicum Infection in Oncomelania hupensis Snails. Trop. Med. Infect. Dis. 2018, 15, 124. [CrossRef]

123. Mwangi, I.N.; Agola, E.L.; Mugambi, R.M.; Shiraho, E.A.; Mkoji, G.M. Development and evaluation of a loop-mediated isothermal amplification assay for diagnosis of Schistosoma mansoni infection in faecal samples. J. Parasitol. Res. 2018, 2018, 1267826. [CrossRef]

124. Kumagai, T.; Furushima-Shimogawara, R.; Ohmae, H.; Wang, T.P.; Lu, S.; Chen, R.; Wen, L.; Ohta, N. Detection of early and single infections of Schistosoma japonicum in the intermediate host snail, Oncomelania hupensis, by PCR and loop-mediated isothermal amplification (LAMP) assay. Am. J. Trop. Med. Hyg. 2010, 83, 542-548. [CrossRef]

125. Hamburger, J.; Abbasi, I.; Kariuki, C.; Wanjala, A.; Mzungu, E.; Mungai, P.; Muchiri, E.; King, C.H. Evaluation of loop-mediated isothermal amplification suitable for molecular monitoring of schistosome-infected snails in field laboratories. Am. J. Trop. Med. Hyg. 2013, 88, 344-351. [CrossRef]

126. Gandasegui, J.; Fernández-Soto, P.; Muro, A.; Lopes de Melo, F.; Loyo, R.; de Souza Gomes, C. A field survey using LAMP assay for detection of Schistosoma mansoni in a low-transmission area of schistosomiasis in Umbuzeiro, Brazil: Assessment in human and snail samples. PLoS Negl. Trop. Dis. 2018, 12, e0006314. [CrossRef]

127. Gandasegui, J.; Fernandez-Soto, P.; Hernandez-Goenaga, J.; Lopez-Aban, J.; Vicente, B.; Muro, A. Biompha-lamp: A new rapid loop-mediated isothermal amplification assay for detecting Schistosoma mansoni in Biomphalaria glabrata snail host. PLoS Negl. Trop. Dis. 2016, 10, e0005225. [CrossRef]

128. Fernández-Soto, P.; Gandasegui Arahuetes, J.; Sánchez Hernández, A.; López Abán, J.; Vicente Santiago, B.; Muro, A. A LoopMediated Isothermal Amplification (LAMP) Assay for Early Detection of Schistosoma mansoni in Stool Samples: A Diagnostic Approach in a Murine Model (LAMP Assay for Early Detection of Schistosoma mansoni in Stool Samples). PLoS Negl. Trop. Dis. 2014, 8, e3126. [CrossRef]

129. Abbasi, I.; King, C.H.; Muchiri, E.M.; Hamburger, J. Detection of Schistosoma mansoni and Schistosoma haematobium DNA by loop-mediated isothermal amplification: Identification of infected snails from early prepatency. Am. J. Trop. Med. Hyg. 2010, 83, 427-432. [CrossRef]

130. Vincent, M.; Xu, Y.; Kong, H. Helicase-dependent isothermal DNA amplification. EMBO Rep. 2004, 5, 795-800. [CrossRef]

131. Piepenburg, O.; Williams, C.H.; Stemple, D.L.; Armes, N.A. DNA detection using recombination proteins. PloS Biol. 2006, 4, 1115. [CrossRef]

132. Compton, J. Nucleic acid sequence-based amplification. Nature 1991, 350, 91. [CrossRef]

133. Xing, W.; Yu, X.; Feng, J.; Sun, K.; Fu, W.; Wang, Y.; Zou, M.; Xia, W.; Luo, Z.; He, H.; et al. Field evaluation of a recombinase polymerase amplification assay for the diagnosis of Schistosoma japonicum infection in Hunan province of China. BMC Infect. Dis. 2017, 17, 164. [CrossRef]

134. Sun, K.; Xing, W.; Yu, X.; Fu, W.; Wang, Y.; Zou, M.; Luo, Z.; Xu, D. Recombinase polymerase amplification combined with a lateral flow dipstick for rapid and visual detection of Schistosoma japonicum. Parasit Vectors 2016, 9, 476. [CrossRef] [PubMed]

135. Rostron, P.; Pennance, T.; Bakar, F.; Rollinson, D.; Knopp, S.; Allan, F.; Kabole, F.; Ali, S.M.; Ame, S.M.; Webster, B.L. Development of a recombinase polymerase amplification (RPA) fluorescence assay for the detection of Schistosoma haematobium. Parasites Vectors 2019, 12, 514. [CrossRef] 
136. Poulton, K.; Webster, B. Development of a lateral flow recombinase polymerase assay for the diagnosis of Schistosoma mansoni infections. Anal. Biochem. 2018, 546, 65-71. [CrossRef]

137. Kato-Hayashi, N.; Yasuda, M.; Yuasa, J.; Isaka, S.; Haruki, K.; Ohmae, H.; Osada, Y.; Kanazawa, T.; Chigusa, Y. Use of cell-free circulating schistosome DNA in serum, urine, semen, and saliva to monitor a case of refractory imported schistosomiasis hematobia. J. Clin. Microbiol. 2013, 51, 3435-3438. [CrossRef]

138. van Dam, G.J.; Wichers, J.H.; Ferreira, T.M.F.; Ghati, D.; van Amerongen, A.; Deelder, A.M. Diagnosis of schistosomiasis by reagent strip test for detection of circulating cathodic antigen. J. Clin. Microbiol. 2004, 42, 5458-5461. [CrossRef] [PubMed]

139. van Dam, G.J.; de Dood, C.J.; Lewis, M.; Deelder, A.M.; van Lieshout, L.; Tanke, H.J.; van Rooyen, L.H.; Corstjens, P.L. A robust dry reagent lateral flow assay for diagnosis of active schistosomiasis by detection of Schistosoma circulating anodic antigen. Exp. Parasitol. 2013, 135, 274-282. [CrossRef] [PubMed]

140. Grenfell, R.F.; Martins, W.; Drummond, S.C.; Antunes, C.M.; Voieta, I.; Otoni, A.; Oliveira, A.A.; Silva-Moraes, V.; Oliveira, E.R.; Oliveira, E.; et al. Acute schistosomiasis diagnosis: A new tool for the diagnosis of schistosomiasis in a group of travelers recently infected in a new focus of Schistosoma mansoni. Rev. Soc. Bras. Med. Trop. 2013, 46, 208-213. [CrossRef]

141. Marchese, V.; Beltrame, A.; Angheben, A.; Monteiro, G.B.; Giorli, G.; Perandin, F.; Buonfrate, D.; Bisoffi, Z. Schistosomiasis in immigrants, refugees and travellers in an Italian referral centre for tropical diseases. Infect. Dis. Poverty $2018,7,55$. [CrossRef] [PubMed]

142. Beltrame, A.; Zammarchi, L.; Zuglian, G.; Gobbi, F.; Angheben, A.; Marchese, V.; Degani, M.; Mantella, A.; Bianchi, L.; Montagnani, C.; et al. Schistosomiasis screening of travelers from Italy with possible exposure in Corsica, France. Emerg. Infect. Dis. 2015, 21, 1887-1889. [CrossRef]

143. Tosswill, J.H.; Ridley, D.S. An evaluation of the ELISA for schistosomiasis in a hospital population. Trans. R. Soc. Trop. Med. Hyg. 1986, 80, 435-438. [CrossRef]

144. Mott, K.E.; Dixon, H.; Osei-Tutu, E.; England, E.C. Relation between intensity of Schistosoma haematobium infection and clinical haematuria and proteinuria. Lancet 1983, 321, 1005-1008. [CrossRef]

145. Ochodo, E.A.; Gopalakrishna, G.; Spek, B.; Reitsma, J.B.; van Lieshout, L.; Polman, K.; Lamberton, P.; Bossuyt, P.M.; Leeflang, M.M. Circulating antigen tests and urine reagent strips for diagnosis of active schistosomiasis in endemic areas. Cochrane Database Syst. Rev. 2015, 2015, Cd009579. [CrossRef]

146. Adekiya, T.A.; Aruleba, R.T.; Oyinloye, B.E.; Okosun, K.O.; Kappo, A.P. The effect of climate change and the snail-schistosome cycle in transmission and bio-control of schistosomiasis in sub-Saharan Africa. Int. J. Environ. Research Public Health 2019, 17, 181. [CrossRef]

147. Rollinson, D.; Knopp, S.; Levitz, S.; Stothard, J.R.; Tchuem Tchuenté, L.-A.; Garba, A.; Mohammed, K.A.; Schur, N.; Person, B.; Colley, D.G.; et al. Time to set the agenda for schistosomiasis elimination. Acta Trop. 2013, 128, 423-440. [CrossRef]

148. McManus, D.P.; Gordon, C.; Weerakoon, K.G.A.D. Testing of water samples for environmental DNA as a surveillance tool to assess the risk of schistosome infection in a locality. Int. J. Infect. Dis. 2018, 76, 128-129. [CrossRef]

149. Allan, F.; Ame, S.M.; Tian-Bi, Y.-N.T.; Hofkin, B.V.; Webster, B.L.; Diakité, N.R.; N'Goran, E.K.; Kabole, F.; Khamis, I.S.; Gouvras, A.N.; et al. Snail-related contributions from the schistosomiasis consortium for operational research and evaluation program including xenomonitoring, focal mollusciciding, biological control, and modeling. Am. Soc. Trop. Med. Hyg. 2020, 103 (Suppl. S1), 66-79. [CrossRef] [PubMed]

150. Sokolow, S.H.; Huttinger, E.; Jouanard, N.; Hsieh, M.H.; Lafferty, K.D.; Kuris, A.M.; Riveau, G.; Senghor, S.; Thiam, C.; N’Diaye, A.; et al. Reduced transmission of human schistosomiasis after restoration of a native river prawn that preys on the snail intermediate host. Proc. Natl. Acad. Sci. USA 2015, 112, 9650-9655. [CrossRef] [PubMed]

151. Yang, K.; Sun, L.P.; Liang, Y.S.; Wu, F.; Li, W.; Zhang, J.F.; Huang, Y.X.; Hang, D.R.; Liang, S.; Bergquist, R.; et al. Schistosoma japonicum risk in Jiangsu province, People's Republic of China: Identification of a spatio-temporal risk pattern along the Yangtze River. Geospat. Health 2013, 8, 133-142. [CrossRef]

152. Hamburger, J.; Xu, Y.; Ramzy, R.M.; Jourdane, J.; Ruppel, A. Development and laboratory evaluation of a polymerase chain reaction for monitoring Schistosoma mansoni infestation of water. Am. J. Trop. Med. Hyg. 1998, 59, 468-473. [CrossRef]

153. Hertel, J.; Kedves, K.; Hassan, A.H.M.; Haberl, B.; Haas, W. Detection of Schistosoma mansoni cercariae in plankton samples by PCR. Acta Trop. 2004, 91, 43-46. [CrossRef] [PubMed]

154. Amarir, F.; Sebti, F.; Abbasi, I.; Sadak, A.; Fellah, H.; Nhammi, H.; Ameur, B.; El Idrissi, A.L.; Rhajaoui, M. Schistosoma haematobium detection in snails by DraI PCR and Sh110/Sm-Sl PCR: Further evidence of the interruption of schistosomiasis transmission in Morocco. Parasites Vectors 2014, 7, 288. [CrossRef] [PubMed]

155. Abbasi, I.; King, C.H.; Sturrock, R.F.; Kariuki, C.; Muchiri, E.; Hamburger, J. Differentiation of Schistosoma haematobium from related schistosomes by PCR amplifying an inter-repeat sequence. Am. J. Trop. Med. Hyg. 2007, 76, 950-955. [CrossRef] [PubMed]

156. Hamburger, J.; Hoffman, O.; Kariuki, H.C.; Muchiri, E.M.; Ouma, J.H.; Koech, D.K.; Sturrock, R.F.; King, C.H. Large-scale, polymerase chain reaction-based surveillance of Schistosoma haematobium DNA in snails from transmission sites in coastal Kenya: A new tool for studying the dynamics of snail infection. Am. J. Trop. Med. Hyg. 2004, 71, 765-773. [CrossRef]

157. Melo, F.L.; Gomes, A.L.; Barbosa, C.S.; Werkhauser, R.P.; Abath, F.G. Development of molecular approaches for the identification of transmission sites of schistosomiasis. Trans. R. Soc. Trop. Med. Hyg. 2006, 100, 1049-1055. [CrossRef] 
158. Sato, M.O.; Rafalimanantsoa, A.; Ramarokoto, C.; Rahetilahy, A.M.; Ravoniarimbinina, P.; Kawai, S.; Minamoto, T.; Sato, M.; Kirinoki, M.; Rasolofo, V.; et al. Usefulness of environmental DNA for detecting Schistosoma mansoni occurrence sites in Madagascar. Int. J. Infect. Dis. 2018, 76, 130-136. [CrossRef] [PubMed]

159. Schols, R.; Carolus, H.; Hammoud, C.; Mulero, S.; Mudavanhu, A.; Huyse, T. A rapid diagnostic multiplex PCR approach for xenomonitoring of human and animal schistosomiasis in a 'One Health' context. Trans. R. Soc. Trop. Med. Hyg. 2019, 113, 722-729. [CrossRef]

160. Pennance, T.; Archer, J.; Lugli, E.B.; Rostron, P.; Llanwarne, F.; Ali, S.M.; Amour, A.K.; Suleiman, K.R.; Li, S.; Rollinson, D.; et al. Development of a Molecular Snail Xenomonitoring Assay to Detect Schistosoma haematobium and Schistosoma bovis Infections in their Bulinus Snail Hosts. Molecules 2020, 25, 4011. [CrossRef]

161. Mahmoud, A.A. Schistosomiasis; Imperial College Press: London, UK, 2001; Volume 3.

162. Sarant, L. Egypt: The flatworm's revenge. Nature 2017, 551, S46-S47. [CrossRef] [PubMed]

163. Ruffer, M.A. Note on the presence of "bilharzia haematobia" in Egyptian mummies of the twentieth dynasty [1250-1000 b.C.]. Br. Med. J. 1910, 1, 16. [CrossRef]

164. Cox, F.E.G. History of Human Parasitology. Clin. Microbiol. Rev. 2002, 15, 595. [CrossRef]

165. Di Bella, S.; Riccardi, N.; Giacobbe, D.R.; Luzzati, R. History of schistosomiasis (bilharziasis) in humans: From Egyptian medical papyri to molecular biology on mummies. Pathog. Glob. Health 2018, 112, 268-273. [CrossRef]

166. Appleton, C.C.; Naidoo, I. Why did schistosomiasis disappear from the southern part of the Eastern Cape? S. Afr. J. Sci. 2012, 108, 1-11. [CrossRef]

167. Harley, J. On the endemic haematuria of the Cape of Good Hope. J. R. Soc. Med. 1864, 47, 55-72. [CrossRef]

168. Bilharz, T.; Siebold, C.T. Ein Beitrag zur Helminhographia humana, aus brieflichen Mitteilungen des Dr. Bilharz in Cairo, nenst Bermerkungen von Prof. C. Th. von Siebold in Breslau. Z. Wiss. Zool. 1852, 4, 53-76.

169. Porter, A. The Larval Trematoda Found in Certain South African Mollusca with Special Eference to Schistosomiasls; Publications of the South African Institute for Medical Research: Bilharzlasls, Congo, 1938; 492p.

170. Gear, J.; Pitchford, R.J.; van Eeden, J.A. Atlas of bilharzia in Southern Africa. Joint publication by the South. African Institute for Medical Research; South African Medical Research Council: Johannesburg, South Africa, 1980.

171. Appleton, C.C.; Kvalsvig, J.D. A school-based helminth control programme successfully implemented in KwaZulu-Natal. S. Afr. J. Epidemiol. Infect. 2006, 21, 55-67. [CrossRef]

172. Utroska, J.A.; Chen, M.G.; Dixon, H.; Yoon, S.-Y.; Helling-Borda, M.; Hogerzeil, H.V.; Mott, K.E.; World Health Organization. Schistosomiasis Control, U. An Estimate of Global Needs for Praziquantel within Schistosomiasis Control Programmes / by J. A. Utroska; World Health Organization: Geneva, Swizterland, 1990.

173. Chernin, E. The curious case of the lateral-spined egg: Schistosoma mansoni. Trans. R. Soc. Trop. Med. Hyg. 1983, 77, 847-850. [CrossRef]

174. WHO. The control of schistosomiasis. Second report of the WHO Expert Committee. Tech. Rep. Ser. 1993, 830, 1-86.

175. WHO. Current Estimated Total Number of Individuals with Morbidity and Mortality due to Schistosomiasis Haematobium and S. Mansoni infection in Sub-Saharan Africa. Schistosomiasis; Epidemiological situation; World Health Organisation: Pretoria, South Africa, 2020.

176. WHO. Regional Office for Africa. 03/06/2020 03/06/2020. Available online: https:/ / espen.afro.who.int/regions/who-africanregion-afro (accessed on 3 June 2020).

177. IAMAT. Travel Health Information. Available online: Iamat.org (accessed on 3 June 2020).

178. Salwa, D.; Hesham, M.A.-M.; Init, I.; Jamaiah, I.; Awatif, M.A.; Abdulhamid, A.; Hany, S.; Nabil, A.N.; Wahib, M.A. The menace of schistosomiasis in Nigeria: Knowledge, attitude, and practices regarding schistosomiasis among rural communities in Kano State. PLoS ONE 2015, 10, e0143667.

179. Cowper, S.G. Schistosomiasis in Nigeria. Ann. Trop. Med. Parasitol. 1963, 57, 307-322. [CrossRef]

180. Ezeh, C.O.; Onyekwelu, K.C.; Akinwale, O.P.; Shan, L.; Wei, H. Urinary schistosomiasis in Nigeria: A 50 year review of prevalence, distribution and disease burden. Parasite 2019, 26, 19. [CrossRef]

181. WHO. Atlas of Global Distribution of Schistosomiasis. Available online: https://www.who.int/schistosomiasis/epidemiology/ en/nigeria.pdf. (accessed on 10 January 2020).

182. World Bank. World Development Report; World Bank: Washington, DC, USA, 1997.

183. Adenowo, A.F.; Oyinloye, B.E.; Ogunyinka, B.I.; Kappo, A.P. Impact of human schistosomiasis in sub-Saharan Africa. Braz. J. Infect. Dis. 2015, 19, 196-205. [CrossRef]

184. Arene, F.; Ukpeibo, E.; Nwanze, E. Studies on schistosomiasis in the Niger Delta: Schistosoma intercalatum in the urban city of Port Harcourt, Nigeria. Public Heal. 1989, 103, 295-301. [CrossRef]

185. Ndukwe, Y.E.; Obiezue, R.N.; Aguzie, I.O.N.; Anunobi, J.T.; Okafor, F.C. Corrigendum: Mapping of Urinary Schistosomiasis in Anambra State, Nigeria. Ann. Glob. Heal. 2019, 85, 85. [CrossRef] [PubMed]

186. King, J.D.; Endeshaw, T.; Escher, E.; Alemtaye, G.; Melaku, S.; Gelaye, W.; Worku, A.; Adugna, M.; Melak, B.; Teferi, T.; et al. Intestinal Parasite Prevalence in an Area of Ethiopia after Implementing the SAFE Strategy, Enhanced Outreach Services, and Health Extension Program. PLoS Negl. Trop. Dis. 2013, 7, e2223. [CrossRef]

187. Atalabi, T.E.; Lawal, U.; Ipinlaye, S.J. Prevalence and intensity of genito-urinary schistosomiasis and associated risk factors among junior high school students in two local government areas around Zobe Dam in Katsina State, Nigeria. Parasites Vectors 2016, 9 , 1-12. [CrossRef] [PubMed] 
188. Atalabi, T.E.; Adoh, S.D.; Eze, K.M. The current epidemiological status of urogenital schistosomiasis among primary school pupils in Katsina State, Nigeria: An imperative for a scale up of water and sanitation initiative and mass administration of medicines with Praziquantel. PLOS Negl. Trop. Dis. 2018, 12, e0006636. [CrossRef]

189. Okoli, C.; Iwuala, M. The prevalence, intensity and clinical signs of urinary schistosomiasis in Imo state, Nigeria. J. Helminthol. 2004, 78, 337-342. [CrossRef]

190. Bocanegra, C.; Gallego, S.; Mendioroz, J.; Moreno, M.; Sulleiro, E.; Salvador, F.; Sikaleta, N.; Nindia, A.; Tchipita, D.; Joromba, M.; et al. Epidemiology of schistosomiasis and usefulness of indirect diagnostic tests in school-age children in Cubal, Central Angola (schistosomiasis in Cubal, Angola). PLoS Negl. Trop. Dis. 2015, 9, e0004055. [CrossRef]

191. Gandasegui, J.; Fernández-Soto, P.; Dacal, E.; Rodríguez, E.; Saugar, J.M.; Yepes, E.; Aznar-Ruiz-De-Alegría, M.L.; Espasa, M.; Ninda, A.; Bocanegra, C.; et al. Field and laboratory comparative evaluation of a LAMP assay for the diagnosis of urogenital schistosomiasis in Cubal, Central Angola. Trop. Med. Int. Health 2018, 23, 992-1001. [CrossRef]

192. Onzo-Aboki, A.; Ibikounlé, M.; Boko, P.M.; Savassi, B.S.; Doritchamou, J.; Siko, E.J.; Daré, A.; Batcho, W.; Massougbodji, A.; Tougoue, J.J.; et al. Human schistosomiasis in Benin: Countrywide evidence of Schistosoma haematobium predominance. Acta Trop. 2019, 191, 185-197. [CrossRef]

193. Ouedraogo, H.; Drabo, F.; Zongo, D.; Bagayan, M.; Bamba, I.; Pima, T.; Yago-Wienne, F.; Toubali, E.; Zhang, Y. Schistosomiasis in school-age children in Burkina Faso after a decade of preventive chemotherapy. Bull. World Heal. Organ. 2015, 94, 37-45. [CrossRef]

194. Lalaye, D.; Bruijn, M.; De Jong, T. Prevalence of Schistosoma haematobium in an unexplored endemic region in the sub-prefecture of Torrock, Chad (Preprint). JMIR Public Health Surveill. 2019, 5. [CrossRef] [PubMed]

195. Angora, E.K.; Boissier, J.; Menan, H.; Rey, O.; Tuo, K.; Touré, A.O.; Coulibaly, J.T.; Méité, A.; Raso, G.; N’Goran, E.K.; et al. Prevalence and risk factors for schistosomiasis among school children in two settings of Côte d'Ivoire. Trop. Med. Infect. Dis. 2019, 4, 110. [CrossRef]

196. Linsuke, S.; Nundu, S.; Mupoyi, S.; Mukele, R.; Mukunda, F.; Kabongo, M.M.; Da Luz, R.I.; Van Geertruyden, J.-P.; Van Sprundel, M.; Boelaert, M.; et al. High Prevalence of Schistosoma mansoni in Six Health Areas of - Kasansa Health Zone, Democratic Republic of the Congo: Short Report. PLoS Negl. Trop. Dis. 2014, 8, e3387. [CrossRef]

197. Da Luz, R.I.; Linsuke, S.; Lutumba, P.; Hasker, E.; Boelaert, M. Assessment of schistosomiasis and soil-transmitted helminths prevalence in school-aged children and opportunities for integration of control in local health services in Kwilu Province, the Democratic Republic of the Congo. Trop. Med. Int. Heal. 2017, 22, 1442-1450. [CrossRef]

198. Gadoth, A.; Mvumbi, G.; Hoff, N.A.; Musene, K.; Mukadi, P.; Ashbaugh, H.R.; Doshi, R.H.; Javanbakht, M.; Gorbach, P.; Okitolonda-Wemakoy, E.; et al. Urogenital Schistosomiasis and Sexually Transmitted Coinfections among Pregnant Women in a Schistosome-Endemic Region of the Democratic Republic of Congo. Am. J. Trop. Med. Hyg. 2019, 101, 828-836. [CrossRef]

199. Kabongo, M.M.; Linsuke, S.; Baloji, S.; Mukunda, F.; Raquel, I.D.L.; Stauber, C.; Van Geertruyden, J.-P.; Lutumba, P. Schistosoma mansoni infection and its association with nutrition and health outcomes: A household survey in school-aged children living in Kasansa, Democratic Republic of the Congo. Pan. Afr. Med. J. 2018, 31, 197. [CrossRef]

200. Knoblauch, A.; Archer, C.; Owuor, M.; Schmidlin, S.; Divall, M.J.; Utzinger, J.; Winkler, M.S. Schistosomiasis and soil-transmitted helminth infections in schoolchildren in north-eastern Democratic Republic of the Congo. Trans. R. Soc. Trop. Med. Hyg. 2016, 110, 424-426. [CrossRef]

201. Kabore, A.; Ibikounle, M.; Tougoue, J.J.; Mupoyi, S.; Ndombe, M.; Shannon, S.; Ottesen, E.A.; Mukunda, F.; Awaca, N. Initiating NTD programs targeting schistosomiasis and soil-transmitted helminthiasis in two provinces of the Democratic Republic of the Congo: Establishment of baseline prevalence for mass drug administration. Acta Trop. 2017, 166, 177-185. [CrossRef]

202. Tchuenté, L.A.T.; Southgate, V.; Vercruysse, J.; Kaukas, A.; Kane, R.; Mulumba, M.; Pagés, J.; Jourdane, J. Epidemiological and genetic observations on human schistosomiasis in Kinshasa, Zaire. Trans. R. Soc. Trop. Med. Hyg. 1997, 91, 263-269. [CrossRef]

203. Elmorshedy, H.; Bergquist, R.; Fayed, A.; Guirguis, W.; Abdel-Gawwad, E.; Eissa, S.; Barakat, R. Elimination of schistosomiasis requires multifactorial diagnostics: Evidence from high- and low-prevalence areas in the Nile Delta, Egypt. Infect. Dis. Poverty 2020, 9, 1-13. [CrossRef] [PubMed]

204. El Sharazly, B.; Abou Rayia, D.; Antonios, S.; Eissa, S.H. Current status of Schistosoma mansoni infection and its snail host in three rural areas in Gharbia governorate, Egypt. Tanta Med. J. 2016, 44, 141-150. [CrossRef]

205. Simarro, P.P.; Sima, F.; Mir, M.; Ndong, P. Effect of repeated targeted mass treatment with praziquantel on the prevalence, intensity of infection and morbidity due to Schistosoma intercalatum in an urban community in equatorial Guinea. Trop. Med. Parasitol Off. Organ Dtsch. Tropenmedizinische Ges. Dtsch. Ges. fur Tech. Zusammenarbeit (GTZ) 1991, 42, 167-171.

206. Simarroi, P.P.; Noong, P.; Mir, M.; Nguema, E. Urban schistosomiasis in Equitorial Guinea. Research and Reviews in Parasitology. Res. Rev. Parasitol. 1993, 53, 93-95.

207. Bekana, T.; Hu, W.; Liang, S.; Erko, B. Transmission of Schistosoma mansoni in Yachi areas, southwestern Ethiopia: new foci. Infect. Dis. Poverty 2019, 8, 1-8. [CrossRef]

208. Alebie, G.; Erko, B.; Aemero, M.; Petros, B. Epidemiological study on Schistosoma mansoni infection in Sanja area, Amhara region, Ethiopia. Parasites Vectors 2014, 7, 15. [CrossRef]

209. Bajiro, M.; Dana, D.; Ayana, M.; Emana, D.; Mekonnen, Z.; Zawdie, B.; Garbi, A.; Kure, A.; Zeynudin, A. Prevalence of Schistosoma mansoni infection and the therapeutic efficacy of praziquantel among school children in Manna District, Jimma Zone, southwest Ethiopia. Parasites Vectors 2016, 9, 560. [CrossRef] 
210. Alemayehu, B.; Tomass, Z.; Wadilo, F.; Leja, D.; Liang, S.; Erko, B. Epidemiology of intestinal helminthiasis among school children with emphasis on Schistosoma mansoni infection in Wolaita zone, Southern Ethiopia. BMC Public Heal. 2017, 17, 1-10. [CrossRef]

211. Kenguele, H.M.; Adegnika, A.A.; Nkoma, A.-M.; Ateba-Ngoa, U.; Mbong, M.; Zinsou, J.F.; Lell, B.; Verweij, J.J.; Gabon, S. Short report: Impact of short-time urine freezing on the sensitivity of an established Schistosoma real-time PCR assay. Am. J. Trop. Med. Hyg. 2014. [CrossRef] [PubMed]

212. Dejon-Agobé, J.C.; Edoa, J.R.; Honkpehedji, Y.J.; Zinsou, J.F.; Adegbite, B.R.; Ngwese, M.M.; Mangaboula, A.; Lell, B.; Grobusch, M.P.; Mordmüller, B.; et al. Schistosoma haematobium infection morbidity, praziquantel effectiveness and reinfection rate among children and young adults in Gabon. Parasites Vectors 2019, 12,1-11. [CrossRef]

213. Sanneh, B.; Joof, E.; Sanyang, A.M.; Renneker, K.; Camara, Y.; Sey, A.P.; Jagne, S.; Baldeh, I.; Ceesay, S.J.; Sambou, S.M.; et al. Field evaluation of a schistosome circulating cathodic antigen rapid test kit at point-of-care for mapping of schistosomiasis endemic districts in The Gambia. PLoS ONE 2017, 12, e0182003. [CrossRef]

214. Anyan, W.K.; Pulkkila, B.R.; Dyra, C.E.; Price, M.; Naples, J.M.; Quartey, J.K.; Anang, A.K.; Lodh, N. Assessment of dual schistosome infection prevalence from urine in an endemic community of Ghana by molecular diagnostic approach. Parasite Epidemiol. Control 2020, 9, e00130. [CrossRef]

215. Cunningham, L.J.; Campbell, S.J.; Armoo, S.; Koukounari, A.; Watson, V.; Selormey, P.; Stothard, J.R.; Idun, B.; Asiedu, M.; Ashong, Y.; et al. Assessing expanded community wide treatment for schistosomiasis: Baseline infection status and self-reported risk factors in three communities from the Greater Accra region, Ghana. PLoS Negl. Trop. Dis. 2020, 14, e0007973. [CrossRef]

216. Hodges, M.; Koroma, M.M.; Baldé, M.S.; Turay, H.; Fofanah, I.; Divall, M.J.; Winkler, M.S.; Zhang, Y. Current status of schistosomiasis and soil-transmitted helminthiasis in Beyla and Macenta Prefectures, Forest Guinea. Trans. R. Soc. Trop. Med. Hyg. 2011, 105, 672-674. [CrossRef]

217. Botelho, M.C.; Machado, A.; de Carvalho, A.F.C.; Vilaça, M.; Conceição, O.; Rosa, F.; Alves, H.; Richter, J.; Bordalo, A.A. Schistosoma haematobium in Guinea-Bissau: Unacknowledged morbidity due to a particularly neglected parasite in a particularly neglected country. Parasitol. Res. 2016, 115, 1567-1572. [CrossRef]

218. Vinkeles Melchers, N.V.S.; van Dam, G.J.; Shaproski, D.; Kahama, A.I.; Brienen, E.A.T.; Vennervald, B.J.; van Lieshout, L. Diagnostic performance of Schistosoma Real-Time PCR in urine samples from Kenyan children infected with Schistosoma haematobium: Day-to-day variation and follow-up after praziquantel treatment (Diagnostic Accuracy of Urine Schistosoma PCR). PLoS Negl. Trop. Dis. 2014, 8, e2807. [CrossRef] [PubMed]

219. Foo, K.T.; Matete, D.O.; Karanja, D.M.S.; Mwinzi, P.N.M.; Secor, W.E.; Montgomery, S.P.; Blackstock, A.J.; Ochola, E.A. Evaluation of Point-of-Contact Circulating Cathodic Antigen Assays for the Detection of Schistosoma mansoni Infection in Low-, Moderate-, and High-Prevalence Schools in Western Kenya. Am. J. Trop. Med. Hyg. 2015, 92, 1227-1232. [CrossRef]

220. Odiere, M.R.; Rawago, F.; Ombok, M.; Secor, W.E.; Karanja, D.M.S.; Mwinzi, P.N.M.; Lammie, P.J.; Won, K. High prevalence of schistosomiasis in Mbita and its adjacent islands of Lake Victoria, western Kenya. Parasites Vectors 2012, 5, 278. [CrossRef] [PubMed]

221. Kazura, J.W.; Dennis, E.; Neill, M.; Peters, P.A.S. Swamp Rice Farming: Possible Effects on Endemicity of Schistosomiasis Mansoni and Haematobia in a Population in Liberia. Am. J. Trop. Med. Hyg. 1985, 34, 107-111. [CrossRef] [PubMed]

222. Fischer, K.; Gankpala, A.; Gankpala, L.; Bolay, F.K.; Curtis, K.C.; Weil, G.J.; Fischer, P.U. Capillaria Ova and Diagnosis of Trichuris trichiura Infection in Humans by Kato-Katz Smear, Liberia. Emerg. Infect. Dis. 2018, 24, 1551-1554. [CrossRef] [PubMed]

223. Pillay, P.; Downs, J.; Changalucha, J.; Brienen, E.; Ramarokoto, C.; Leutscher, P.; Vennervald, B.; Taylor, M.; Kjetland, E.; Van Lieshout, L. Detection of Schistosoma DNA in genital specimens and urine: A comparison between five female African study populations originating from S. haematobium and/or S. mansoni endemic areas. Acta Trop. 2020, 204, 105363. [CrossRef]

224. Rasoamanamihaja, C.F.; Rahetilahy, A.M.; Ranjatoarivony, B.; Dhanani, N.; Andriamaro, L.; Andrianarisoa, S.H.; Jourdan, P.M. Baseline prevalence and intensity of schistosomiasis at sentinel sites in Madagascar: Informing a national control strategy. Parasites Vectors 2016, 9, 1-10. [CrossRef] [PubMed]

225. Spencer, S.A.; Penney, J.M.S.J.; Russell, H.J.; Howe, A.P.; Linder, C.; Rakotomampianina, A.L.D.; Nandimbiniaina, A.M.; Squire, S.B.; Stothard, J.R.; Bustinduy, A.L.; et al. High burden of Schistosoma mansoni infection in school-aged children in Marolambo District, Madagascar. Parasites Vectors 2017, 10, 307. [CrossRef]

226. Moyo, V.; Changadeya, W.; Chiotha, S.; Sikawa, D. Urinary schistosomiasis among preschool children in Malengachanzi, Nkhotakota District, Malawi: Prevalence and risk factors. Malawi Med. J. 2016, 28, 10-14. [CrossRef]

227. Kayuni, S.; Peeling, R.; Makaula, P. Prevalence and distribution of Schistosoma haematobium infection among school children living in southwestern shores of Lake Malawi. Malawi Med. J. 2017, 29, 16-23. [CrossRef]

228. Dabo, A.; Badawi, H.M.; Bary, B.; Doumbo, O.K. Urinary schistosomiasis among preschool-aged children in Sahelian rural communities in Mali. Parasites Vectors 2011, 4, 21. [CrossRef]

229. Landouré, A.; Dembélé, R.; Goita, S.; Kané, M.; Tuinsma, M.; Sacko, M.; Toubali, E.; French, M.D.; Keita, A.D.; Fenwick, A.; et al. Significantly reduced intensity of infection but persistent prevalence of schistosomiasis in a highly endemic region in Mali after repeated treatment. PLoS Negl. Trop. Dis. 2012, 6, e1774. [CrossRef]

230. Gbalégba, N.G.C.; Silué, K.D.; Ba, O.; Ba, H.; Tian-Bi, N.T.Y.; Yapi, G.Y.; Kaba, A.; Koné, B.; Utzinger, J.; Koudou, B.G. Prevalence and seasonal transmission of Schistosoma haematobium infection among school-aged children in Kaedi town, southern Mauritania. Parasites Vectors 2017, 10, 353. [CrossRef] 
231. Urbani, C.; Touré, A.; O Hamed, A.; Albonico, M.; Kane, I.; Cheikna, D.; Hamed, N.; Montresor, A.; Savioli, L. Intestinal parasitic infections and schistosomiasis in the valley of the Senegal river in the Islamic Republic of Mauritania. Med. Trop. Rev. Du Corps De Sante Colon. 1997, 57, 157-160.

232. Salem, C.B.O.A.; Boussery, A.; Hafid, J. Study of prevalence and parasite load of Schistosoma haematobium in schoolchildren in the Rosso region, Mauritania. Med. Sante Trop. 2019, 29, 268-272.

233. Phillips, A.E.; Gazzinelli-Guimarães, P.H.; Aurelio, H.O.; Dhanani, N.; Ferro, J.; Nala, R.; Deol, A.; Fenwick, A. Urogenital schistosomiasis in Cabo Delgado, northern Mozambique: Baseline findings from the SCORE study. Parasites Vectors 2018, 11, 30. [CrossRef]

234. Casmo, V.; Augusto, G.; Nala, R.; Sabonete, A. and Carvalho-Costa, F.A. The effect of hookworm infection and urinary schistosomiasis on blood hemoglobin concentration of schoolchildren living in northern Mozambique. Rev. Do Inst. De Med. Trop. De Sao Paulo 2014, 56, 219-224. [CrossRef] [PubMed]

235. Augusto, G.; Nala, R.; Casmo, V.; Sabonete, A.; Mapaco, L.; Monteiro, J. Geographic distribution and prevalence of schistosomiasis and soil-transmitted hhelminths among schoolchildren in Mozambique. Am. J. Trop. Med. Hyg. 2009, 81, 799-803. [CrossRef]

236. Sousa-Figueiredo, J.C.; Stanton, M.C.; Katokele, S.; Arinaitwe, M.; Adriko, M.; Balfour, L.; Reiff, M.; Lancaster, W.; Noden, B.H.; Bock, R.; et al. Mapping of Schistosomiasis and Soil-Transmitted Helminths in Namibia: The First Large-Scale Protocol to Formally Include Rapid Diagnostic Tests. PLoS Negl. Trop. Dis. 2015, 9, e0003831. [CrossRef]

237. Ibironke, O.A.; Shiff, C.; Garba, A.; Phillips, A.E.; Lamine, S.M. Diagnosis of Schistosoma haematobium by Detection of Specific DNA Fragments from Filtered Urine Samples. Am. J. Trop. Med. Hyg. 2011, 84, 998-1001. [CrossRef] [PubMed]

238. Bakare, S.; Adebayo, A.; Awobode, H.; Onile, O.; Agunloye, A.; Isokpehi, R.; Anumudu, C. Arsenicosis in bladder pathology and schistosomiasis in Eggua, Nigeria. Trans. R. Soc. Trop. Med. Hyg. 2018, 112, 230-237. [CrossRef]

239. Otuneme, O.G.; O Obebe, O.; Sajobi, T.T.; Akinleye, W.; Faloye, T.G. Prevalence of Schistosomiasis in a neglected community, South western Nigeria at two points in time, spaced three years apart. Afr. Heal. Sci. 2019, 19, 1338-1345. [CrossRef]

240. Eyong, M.; E Ikepeme, E.; Ekanem, E. Relationship between Schistosoma haematobium infection and urinary tract infection among children in South Eastern, Nigeria. Niger. Postgrad. Med. J. 2008, 15, 89-93.

241. Ekanem, E.E.; Akapan, F.M.; Eyong, M.E. Urinary schistosomiasis in school children of a southern nigerian community 8 years after the provision of potable water. Niger. Postgrad. Med. J. 2017, 24, 201. [CrossRef] [PubMed]

242. Josh, R.; Blaise, K.; Denise, M.; Eugene, R.; Nadine, R.; Gaspard, K.; Corine, K.; Deville, M.; Fenwick, A. School Prevalence Surveys on Soil Transmitted Helminths and Schistosomiasis, Rwanda. Int. J. Infect. Dis. 2008, 12, e376. [CrossRef]

243. Hove, R.J.T.; Verweij, J.J.; Vereecken, K.; Polman, K.; Dieye, L.; Van Lieshout, L. Multiplex real-time PCR for the detection and quantification of Schistosoma mansoni and S. haematobium infection in stool samples collected in northern Senegal. Trans. R. Soc. Trop. Med. Hyg. 2008, 102, 179-185. [CrossRef]

244. Sacolo-Gwebu, H.; Chimbari, M.; Kalinda, C. Prevalence and risk factors of schistosomiasis and soil-transmitted helminthiases among preschool aged children (1-5 years) in rural KwaZulu-Natal, South Africa: A cross-sectional study. Infect. Dis. Poverty 2019, 8, 47. [CrossRef]

245. Rubaba, O.; Chimbari, M.; Soko, W.; Manyangadze, T.; Mukaratirwa, S. Validation of a urine circulating cathodic antigen cassette test for detection of Schistosoma haematobiumin uMkhanyakude district of South Africa. Acta Trop. 2018, 182, 161-165. [CrossRef]

246. Pillay, P.; Kjetland, E.F.; Brienen, E.A.T.; Taylor, M.; Van Lieshout, L.; Gundersen, S.G.; Hoekstra, P.; Zulu, S.G.; Verweij, J.J.; Kleppa, E. Real-Time Polymerase Chain Reaction for Detection of Schistosoma DNA in Small-Volume Urine Samples Reflects Focal Distribution of Urogenital Schistosomiasis in Primary School Girls in KwaZulu Natal, South Africa. Am. J. Trop. Med. Hyg. 2014, 90, 546-552. [CrossRef]

247. Kabuyaya, M.; Chimbari, M.J.; Manyangadze, T.; Mukaratirwa, S. Schistosomiasis risk factors based on the infection status among school-going children in the Ndumo area, Umkhanyakude district. S. Afr. J. Infect. Dis. 2017, 32, 67-72.

248. Eltoum, I.A.; Sulaiman, S.M.; Elturabi, H.; Mahgoub, E.; Homeida, M.M. Infection with Schistosoma mansoni in two different endemic areas: A comparative population-based study in Elziedab and Gezira-Managil irrigation schemes, Sudan. J. Trop. Med. Hyg. 1993, 96, 100-106. [PubMed]

249. Song, H.B.; Kim, J.; Jin, Y.; Lee, J.S.; Jeoung, H.G.; Lee, Y.H.; Saeed, A.A.W.; Hong, S.-T. Comparison of ELISA and Urine Microscopy for Diagnosis ofSchistosoma haematobiumInfection. J. Korean Med. Sci. 2018, 33, e238. [CrossRef]

250. Liao, C.W.; Sukati, H.; Nara, T.; Tsubouchi, A.; Chou, C.-M.; Jian, J.-Y.; Huang, Y.-C.; Chang, P.W.-S.; Chiu, W.-T.; Huang, Y.-H.; et al. Prevalence of Schistosoma haematobium infection among schoolchildren in remote areas devoid of sanitation in northwestern Swaziland, Southern Africa. JPN. J. Infect. Dis. 2011, 64, 322-326.

251. Chu, T.B.; Liao, C.W.; D'Lamini, P.; Chang, P.W.S.; Chiu, W.T.; Du, W.Y.; Fan, C.K. Prevalence of Schistosoma haematobium infection among inhabitants of Lowveld, Swaziland, an endemic area for the disease. Trop. Biomed. 2010, $27,337-342$.

252. Fuss, A.; Mazigo, H.D.; Tappe, D.; Kasang, C.; Mueller, A. Comparison of sensitivity and specificity of three diagnostic tests to detect Schistosoma mansoni infections in school children in Mwanza region, Tanzania. PLoS ONE 2018, 13, e0202499. [CrossRef]

253. Mueller, A.; Fuss, A.; Ziegler, U.; Kaatano, G.M.; Mazigo, H.D. Intestinal schistosomiasis of Ijinga Island, north-western Tanzania: Prevalence, intensity of infection, hepatosplenic morbidities and their associated factors. BMC Infect. Dis. 2019, 19, 1-12. [CrossRef]

254. Mnkugwe, R.H.; Minzi, O.S.; Kinung'hi, S.M.; Kamuhabwa, A.A.; Aklillu, E. Prevalence and correlates of intestinal schistosomiasis infection among school-aged children in North-Western Tanzania. PLoS ONE 2020, 15, e0228770. [CrossRef] [PubMed] 
255. Siza, J.E.; Kaatano, G.M.; Chai, J.-Y.; Eom, K.S.; Rim, H.-J.; Yong, T.-S.; Min, D.-Y.; Chang, S.Y.; Ko, Y.; Changalucha, J.M. Prevalence of schistosomes and soil-transmitted Helminths among school children in Lake Victoria Basin, Tanzania. Korean J. Parasitol. 2015, 53, 515-524. [CrossRef] [PubMed]

256. Munisi, D.Z.; Buza, J.; Mpolya, E.A.; Kinung'hi, S.M. Intestinal schistosomiasis among primary schoolchildren in two on-shore communities in Rorya District, Northwestern Tanzania: Prevalence, intensity of infection and associated risk factors. J. Parasitol. Res. 2016, 2016, 1859737. [CrossRef]

257. Al-Shehri, H.; Koukounari, A.; Stanton, M.C.; Adriko, M.; Arinaitwe, M.; Atuhaire, A.; Kabatereine, N.B.; Stothard, J.R. Surveillance of intestinal schistosomiasis during control: A comparison of four diagnostic tests across five Ugandan primary schools in the Lake Albert region. Parasitology 2018, 145, 1715-1722. [CrossRef]

258. Nalugwa, A.; Olsen, A.; Tukahebwa, M.; Nuwaha, F. Intestinal schistosomiasis among preschool children along the shores of Lake Victoria in Uganda. Acta Trop. 2015, 142, 115-121. [CrossRef]

259. Kabatereine, N.B.; Standley, C.J.; Sousa-Figueiredo, J.C.; Fleming, F.M.; Stothard, J.R.; Talisuna, A.; Fenwick, A. Integrated prevalence mapping of schistosomiasis, soil-transmitted helminthiasis and malaria in lakeside and island communities in Lake Victoria, Uganda. Parasites Vectors 2011, 4, 232. [CrossRef] [PubMed]

260. Betson, M.; Sousa-Figueiredo, J.C.; Rowell, C.; Kabatereine, N.B.; Stothard, J.R. Intestinal Schistosomiasis in Mothers and Young Children in Uganda: Investigation of Field-Applicable Markers of Bowel Morbidity. Am. J. Trop. Med. Hyg. 2010, 83, 1048-1055. [CrossRef] [PubMed]

261. Adriko, M.; Tinkitina, B.; Tukahebw, E.; Standley, C.; Stothard, J.; Kabatereine, N. The epidemiology of schistosomiasis in Lango region Uganda 60 years after Schwetz 1951: Can schistosomiasis be eliminated through mass drug administration without other supportive control measures? Acta Trop. 2018, 185, 412-418. [CrossRef] [PubMed]

262. Zhang, L.-J.; Mwanakasale, V.; Xu, J.; Sun, L.-P.; Yin, X.-M.; Zhang, J.-F.; Hu, M.-C.; Si, W.-M.; Zhou, X.-N. Diagnostic performance of two specific schistosoma japonicum immunological tests for screening schistosoma haematobium in school children in Zambia. Acta Trop. 2020, 202, 105285. [CrossRef]

263. Agnew-Blais, J.; Carnevale, J.; Gropper, A.; Shilika, E.; Bail, R.; Ngoma, M. Schistosomiasis Haematobium Prevalence and Risk Factors in a School-age Population of Peri-urban Lusaka, Zambia. J. Trop. Pediatr. 2009, 56, 247-253. [CrossRef] [PubMed]

264. Chama, M.F.; Shehata, M.A.; Funjika, E. Prevalence and intensity of Schistosoma haematobium infection among schoolchildren in central Zambia before and after mass treatment with a single dose of praziquantel. Trop. Parasitol. 2018, 8, 12-17. [CrossRef] [PubMed]

265. Mutengo, M.M.; Mduluza, T.; Chipeta, J.; Sianongo, S.; Mwansa, J.C.L. High Schistosoma mansoni Disease Burden in a Rural District of Western Zambia. Am. J. Trop. Med. Hyg. 2014, 91, 965-972. [CrossRef] [PubMed]

266. Nausch, N.; Dawson, E.M.; Midzi, N.; Mduluza, T.; Mutapi, F.; Doenhoff, M.J. Field evaluation of a new antibody-based diagnostic for Schistosoma haematobium and S. mansoniat the point-of-care in northeast Zimbabwe. BMC Infect. Dis. 2014, 14, 165. [CrossRef]

267. Midzi, N.; Mduluza, T.; Chimbari, M.J.; Tshuma, C.; Charimari, L.; Mhlanga, G.; Manangazira, P.; Munyati, S.M.; Phiri, I.; Mutambu, S.L.; et al. Distribution of Schistosomiasis and Soil Transmitted Helminthiasis in Zimbabwe: Towards a National Plan of Action for Control and Elimination. PLoS Negl. Trop. Dis. 2014, 8, e3014. [CrossRef]

268. Mutsaka-Makuvaza, M.J.; Matsena-Zingoni, Z.; Katsidzira, A.; Tshuma, C.; Chin'Ombe, N.; Zhou, X.-N.; Webster, B.; Midzi, N. Urogenital schistosomiasis and risk factors of infection in mothers and preschool children in an endemic district in Zimbabwe. Parasites Vectors 2019, 12, 1-15. [CrossRef]

269. Mazigo, H.D.; Nuwaha, F.; Kinung'hi, S.M.; Morona, D.; Pinot de Moira, A.; Wilson, S.; Heukelbach, J.; Dunne, D.W. Epidemiology and control of human schistosomiasis in Tanzania. Parasites Vectors 2012, 5, 274. [CrossRef] [PubMed]

270. Brooker, S.; Clements, A.C. Spatial heterogeneity of parasite co-infection: Determinants and geostatistical prediction at regional scales. Int. J. Parasitol. 2009, 39, 591-597. [CrossRef]

271. McCullough, F.S. The distribution of Schistosoma mansoni and S. haematobium in East Africa. Trop. Geogr. Med. 1972, 24, 199-207.

272. Clements, A.C.; Lwambo, N.J.; Blair, L.; Nyandindi, U.; Kaatano, G.; Kinung'hi, S.; Webster, J.P.; Fenwick, A.; Brooker, S. Bayesian spatial analysis and disease mapping: Tools to enhance planning and implementation of a schistosomiasis control programme in Tanzania. Trop. Med. Int. Health 2006, 11, 490-503. [CrossRef]

273. Brooker, S.; Kabatereine, N.B.; Gyapong, J.O.; Stothard, J.R.; Utzinger, J. Rapid mapping of schistosomiasis and other neglected tropical diseases in the context of integrated control programmes in Africa. Parasitology 2009, 136, 1707-1718. [CrossRef] [PubMed]

274. Rimoin, A.W.; Hotez, P.J. NTDs in the Heart of Darkness: The Democratic Republic of Congo's Unknown Burden of Neglected Tropical Diseases. PLoS Negl. Trop. Dis. 2013, 7, e2118. [CrossRef] [PubMed]

275. Madinga, J.; Linsuke, S.; Mpabanzi, L.; Meurs, L.; Kanobana, K.; Speybroeck, N.; Lutumba, P.; Polman, K. Schistosomiasis in the Democratic Republic of Congo: A literature review. Parasites Vectors 2015, 8, 601. [CrossRef] [PubMed]

276. Kumbu, R.K.; Makola, K.M.; Bin, L. Prevalence of Schistosoma mansoni Infection in Four Health Areas of Kisantu Health Zone, Democratic Republic of the Congo. Adv. Med. 2016, 2016, 1-5. [CrossRef]

277. Gyasi, S.F.; Boateng, A.A.; Awuah, E.; Antwi, E.O. Ellucidating the incidence and the prevalence of Schistosomiasis spp infection in riparian communities of the Bui dam. J. Parasit. Dis. 2019, 43, 276-288. [CrossRef]

278. Hotez, P.J.; Savioli, L.; Fenwick, A. Neglected tropical diseases of the Middle East and North Africa: Review of their prevalence, distribution, and opportunities for control. PLoS Negl. Trop. Dis. 2012, 6, e1475. [CrossRef] 
279. Abou-El-Naga, I.F. Towards elimination of schistosomiasis after 5000 years of endemicity in Egypt. Acta Trop. 2018, 181, 112-121. [CrossRef]

280. Fatima, A.; Abdelaali, B.; Corstjens, P.L.A.M.; Abderrahim, S.; El Bachir, A.; Mohamed, R. Survey and Diagnostic Challenges after Transmission-Stop: Confirming Elimination of Schistosomiasis haematobium in Morocco. J. Parasitol. Res. 2020, $2020,1-7$. [CrossRef] [PubMed]

281. Amarir, F.; Fellah, H.; El Mansouri, B.; Wilkins, P.; Rhajaoui, M.; Handali, S.; Mohammed, L.; Sebti, F.; Sadak, A.; El Idrissi, A.L. National Serologic Survey of Haematobium Schistosomiasis in Morocco: Evidence for Elimination. Am. J. Trop. Med. Hyg. 2011, 84, 15-19. [CrossRef]

282. Hedfi, M.; Debaibi, M.; Ben Iahouel, S.; Chouchen, A. Gallbladder schistosomiasis: Rare but possible, a case report and review of the literature. Pan Afr. Med. J. 2019, 32, 91. [PubMed]

283. Horstick, O. Guide National d'Epidémiologie d'Intervention; République Tunisienne Ministère De La Santé Direction des Soins de Santé de Base: Tunisia, North Africa, 2015.

284. WHO. Schistosomiasis: Progress Report 2001-2011 and Strategic Plan 2012-2020; WHO: Geneva, Swizterland, 2012.

285. Emmanuel, I.O.A.; Ekkehard, D. Epidemiology, of bilharzias (schistosomiasis) in Uganda from 1902 until 2005. Afr. Heal. Sci. 2008, 8, 239-243.

286. Nelson, G.S. Schistosoma mansoni infection in the West Nile District of Uganda. I. The incidence of S. mansoni infection. East Afr. Med. J. 1958, 35, 311-319.

287. Rawson, P.A.G.B. Appendix, Annual Report-Uganda Medical Department; Uganda Medical Department: Uganda, East Africa, 1923.

288. Schwetz, J. On vesical Bilharzia in the lango district (Uganda). Trans. R. Soc. Trop. Med. Hyg. 1951, 44, 501-514. [CrossRef]

289. WHO. Atlas of Global Distribution of Schistosomiasis: 30-Uganda; World Health Organisation: Geneva, Swizterland, 1987; pp. 243-247.

290. Ongom, V.L. The earliest age of infection with S. mansoni in West Nile District of Uganda. East Afr. Med. J. 1973, 50, 581-585. [PubMed]

291. Sacolo, H.; Chimbari, M.; Kalinda, C. Knowledge, attitudes and practices on Schistosomiasis in sub-Saharan Africa: A systematic review. BMC Infect. Dis. 2018, 18, 46. [CrossRef]

292. Kalinda, C.; Mutengo, M.; Chimbari, M. A meta-analysis of changes in schistosomiasis prevalence in Zambia: Implications on the 2020 elimination target. Parasitol. Res. 2019, 119, 1-10. [CrossRef] [PubMed]

293. Liese, B.; Rosenberg, M.; Schratz, A. Programmes, partnerships, and governance for elimination and control of neglected tropical diseases. Lancet 2010, 375, 67-76. [CrossRef]

294. Fenwick, A.; Webster, J.P.; Bosque-Oliva, E.; Blair, L.; Fleming, F.M.; Zhang, Y.; Garba, A.; Stothard, R.; Gabrielli, A.F.; Clements, A.C.A.; et al. The Schistosomiasis Control Initiative (SCI): Rationale, development and implementation from 2002-2008. Parasitology 2009, 136, 1719-1730. [CrossRef] [PubMed]

295. Borlase, A.; Webster, J.P.; Rudge, J.W. Opportunities and challenges for modelling epidemiological and evolutionary dynamics in a multihost, multiparasite system: Zoonotic hybrid schistosomiasis in West Africa. Evol. Appl. 2017, 11, 501-515. [CrossRef]

296. Wharton-Smith, A.; Rassi, C.; Batisso, E.; Ortu, G.; King, R.; Endriyas, M.; Counihan, H.; Hamade, P.; Getachew, D. Gender-related factors affecting health seeking for neglected tropical diseases: Findings from a qualitative study in Ethiopia. PLoS Negl. Trop. Dis. 2019, 13, e0007840. [CrossRef] [PubMed]

297. Lubell, H. Gender, Behavior, and Health: Schistosomiasis Transmission and Control in Rural Egypt (Book Review); The University of Chicago Press: Cairo, Egypt, 2005; pp. 1005-1009.

298. Aagaard-Hansen, J.; Mwanga, J.R.; Bruun, B. Social science perspectives on schistosomiasis control in Africa: Past trends and future directions. Parasitology 2009, 136, 1747-1758. [CrossRef] [PubMed]

299. Uniting to Combat Neglected Tropical Diseases. Neglected Tropical Diseases: Women and Girls in Focus. Available online: https://unitingtocombatntds.org/wp-content/uploads/2017/11/women_and_girls_in_focus_english.pdf. (accessed on 2 November 2020).

300. Bangert, M.; Molyneux, D.H.; Lindsay, S.W.; Fitzpatrick, C.; Engels, D. The cross-cutting contribution of the end of neglected tropical diseases to the sustainable development goals. Infect. Dis. Poverty 2017, 6, 1-20. [CrossRef]

301. Amazigo, U.O.; Anago-Amanze, C.I. and Okeibunor, J.C. Urinary schistosomiasis among school children in Nigeria: Consequences of indigenous beliefs and water contact activities. J. Biosoc. Sci. 1997, 29, 9-18. [CrossRef]

302. Hegertun, I.E.A.; Gundersen, K.M.S.; Kleppa, E.; Zulu, S.G.; Gundersen, S.G.; Taylor, M.; Kvalsvig, J.D.; Kjetland, E.F. S haematobium as a Common Cause of Genital Morbidity in Girls: A Cross-sectional Study of Children in South Africa. PLoS Negl. Trop. Dis. 2013, 7, e2104. [CrossRef] [PubMed]

303. Kukula, V.A.; MacPherson, E.E.; Tsey, I.H.; Stothard, J.R.; Theobald, S.; Gyapong, M. A major hurdle in the elimination of urogenital schistosomiasis revealed: Identifying key gaps in knowledge and understanding of female genital schistosomiasis within communities and local health workers. PLoS Negl. Trop. Dis. 2019, 13, e0007207. [CrossRef]

304. Arnold, M.L. Natural Hybridization and Evolution; Oxford University Press: New York, NY, USA, 1997.

305. Arnold, M.L. Natural hybridization and the evolution of domesticated, pest and disease organisms. Mol. Ecol. 2004, 13, 997-1007. [CrossRef]

306. Huyse, T.; Webster, B.; Geldof, S.; Stothard, R.; Diaw, O.T.; Polman, K.; Rollinson, D. Bidirectional Introgressive Hybridization between a Cattle and Human Schistosome Species. PLoS Pathog. 2009, 5, e1000571. [CrossRef] [PubMed] 
307. Tchuenté, L.A.T.; Southgate, V.; Njiokou, F.; Njiné, T.; Kouemeni, L.; Jourdane, J. The evolution of schistosomiasis at Loum, Cameroon: Replacement of Schistosoma intercalatum by S. haematobium through introgressive hybridization. Trans. R. Soc. Trop. Med. Hyg. 1997, 91, 664-665. [CrossRef]

308. Moné, H.; Holtfreter, M.C.; Allienne, J.-F.; Mintsa-Nguéma, R.; Ibikounle, M.; Boissier, J.; Berry, A.; Mitta, G.; Richter, J.; Mouahid, G. Introgressive hybridizations of Schistosoma haematobium by Schistosoma bovis at the origin of the first case report of schistosomiasis in Corsica (France, Europe). Parasitol. Res. 2015, 114, 4127-4133. [CrossRef]

309. Southgate, V.R.; Jourdane, J.; Tchuenté, L.A. Recent studies on the reproductive biology of the schistosomes and their relevance to speciation in the Digenea. Int. J. Parasitol. 1998, 28, 1159-1172. [CrossRef]

310. Wright, C.; Southgate, V.; Knowles, R. What is Schistosoma intercalatum fisher, 1934? Trans. R. Soc. Trop. Med. Hyg. 1972, 66, 28-56. [CrossRef]

311. Bjørneboe, A.; Frandsen, F. A comparison of the characteristics of two strains of Schistosoma intercalatum Fisher, 1934 in mice. J. Helminthol. 1979, 53, 195-203. [CrossRef]

312. Frandsen, F. Hybridization between different strains of Schistosoma intercalatum Fisher, 1934 from Cameroun and Zaïre. J. Helminthol. 1978, 52, 11-22. [CrossRef] [PubMed]

313. Wright, C.; Southgate, V.; Ross, G. Enzymes in Schistosoma intercalatum and the relative status of the Lower Guinea and Zaire strains of the parasite. Int. J. Parasitol. 1979, 9, 523-528. [CrossRef]

314. Brown, D.S.; Sarfati, C.; Southgate, V.R.; Ross, G.C.; Knowles, R.J. Observations onSchistosoma intercalatum in south-east gabon. Parasitol. Res. 1984, 70, 243-253. [CrossRef] [PubMed]

315. Kane, R.A.; Southgate, V.R.; Rollinson, D.; Littlewood, D.T.J.; Lockyer, A.; Pags, J.R.; Tchuent, L.A.T.; Jourdane, J. A phylogeny based on three mitochondrial genes supports the division of Schistosoma intercalatum into two separate species. Parasitology 2003, 127, 131-137. [CrossRef] [PubMed]

316. Pagès, J.R.; Durand, P.; Southgate, V.R.; Tchuenté, L.A.T.; Jourdane, J. Molecular arguments for splitting of Schistosoma intercalatum, into two distinct species. Parasitol. Res. 2001, 87, 57-62. [CrossRef]

317. Moné, H.; Minguez, S.; Ibikounlé, M.; Allienne, J.-F.; Massougbodji, A.; Mouahid, G. Natural Interactions between S. haematobium and S. guineensis in the Republic of Benin. Sci. World J. 2012, 2012, 793420. [CrossRef]

318. Schur, N.; Hürlimann, E.; Stensgaard, A.-S.; Chimfwembe, K.; Mushinge, G.; Simoonga, C.; Kabatereine, N.B.; Kristensen, T.K.; Utzinger, J.; Vounatsou, P. Spatially explicit Schistosoma infection risk in eastern Africa using Bayesian geostatistical modelling. Acta Trop. 2013, 128, 365-377. [CrossRef]

319. Ekpo, U.F.; Hürlimann, E.; Schur, N.; Oluwole, A.S.; Abe, E.M.; Mafe, M.A.; Nebe, O.J.; Isiyaku, S.; Olamiju, F.; Kadiri, M.; et al Mapping and prediction of schistosomiasis in Nigeria using compiled survey data and Bayesian geospatial modelling. Geospat. Heal. 2013, 7, 355-366. [CrossRef] [PubMed]

320. Nguema, R.M.; Mavoungou, J.F.; Ngou-Milama, K.M.M.; Mamfoumbi, M.M.; Koumba, A.A.; Lamine, M.S.; Diarra, A.; Asseko, G.N.; Mourou, J.R.; Akotet, M.K.B.; et al. Baseline Mapping of Schistosomiasis and Soil Transmitted Helminthiasis in the Northern and Eastern Health Regions of Gabon, Central Africa: Recommendations for Preventive Chemotherapy. Trop. Med. Infect. Dis. 2018, 3, 119. [CrossRef] [PubMed]

321. Ndukwe, Y.E.; Obiezue, R.N.N.; Aguzie, I.O.N.; Anunobi, J.T.; Okafor, F.C. Mapping of urinary schistosomiasis in Anambra State, Nigeria. Ann. Glob. Health 2019, 85, 52. [CrossRef]

322. Kabore, A.; Biritwum, N.-K.; Downs, P.W.; Magalhaes, R.J.S.; Zhang, Y.; Ottesen, E.A. Predictive vs. Empiric Assessment of Schistosomiasis: Implications for Treatment Projections in Ghana. PLoS Negl. Trop. Dis. 2013, 7, e2051. [CrossRef]

323. Ekpo, U.F.; Oluwole, A.S.; Abe, E.M.; Etta, H.E.; Olamiju, F.; Mafiana, C.F.; Ekpo, U. Schistosomiasis in infants and pre-school-aged children in sub-Saharan Africa: Implication for control. Parasitology 2012, 139, 835-841. [CrossRef] [PubMed]

324. Stothard, J.R.; Gabrielli, A.-F. Schistosomiasis in African infants and preschool children: To treat or not to treat? Trends Parasitol. 2007, 23, 83-86. [CrossRef]

325. McManus, D.P. Defeating Schistosomiasis. N. Engl. J. Med. 2019, 381, 2567-2568. [CrossRef]

326. Gray, D.J.; McManus, D.P.; Li, Y.; Williams, G.; Bergquist, R.; Ross, A.G. Schistosomiasis elimination: Lessons from the past guide the future. Lancet Infect. Dis. 2010, 10, 733-736. [CrossRef]

327. Williams, G.M.; Li, Y.-S.; Gray, D.J.; Zhao, Z.-Y.; Harn, D.A.; Shollenberger, L.M.; Li, S.-M.; Yu, X.; Feng, Z.; Guo, J.-G.; et al. Field Testing Integrated Interventions for Schistosomiasis Elimination in the People's Republic of China: Outcomes of a Multifactorial Cluster-Randomized Controlled Trial. Front. Immunol. 2019, 10, 645. [CrossRef]

328. Bergquist, R.; Utzinger, J.; McManus, N.P. Trick or Treat: The Role of Vaccines in Integrated Schistosomiasis Control. PLoS Negl. Trop. Dis. 2008, 2, e244. [CrossRef]

329. Simoonga, C.; Utzinger, J.; Brooker, S.; Vounatsou, P.; Appleton, C.C.; Stensgaard, A.-S.; Olsen, A.; Kristensen, T.K. Remote sensing, geographical information system and spatial analysis for schistosomiasis epidemiology and ecology in Africa. Parasitology 2009, 136, 1683-1693. [CrossRef]

330. Walz, Y.; Wegmann, M.; Dech, S.; Raso, G.; Utzinger, J. Risk profiling of schistosomiasis using remote sensing: Approaches, challenges and outlook. Parasites Vectors 2015, 8, 1-16. [CrossRef]

331. Kulinkina, A.V.; Walz, Y.; Koch, M.; Biritwum, N.-K.; Utzinger, J.; Naumova, E.N. Improving spatial prediction of Schistosoma haematobium prevalence in southern Ghana through new remote sensors and local water access profiles. PLoS Negl. Trop. Dis. 2018, 12, e0006517. [CrossRef] 
332. Schur, N.; Hürlimann, E.; Garba, A.; Traore, M.S.; Ndir, O.; Ratard, R.C.; Tchuenté, L.-A.T.; Kristensen, T.K.; Utzinger, J.; Vounatsou, P. Geostatistical Model-Based Estimates of Schistosomiasis Prevalence among Individuals Aged $\leq 20$ Years in West Africa. PLoS Negl. Trop. Dis. 2011, 5, e1194. [CrossRef]

333. Wrable, M.; Kulinkina, A.; Liss, A.; Koch, M.; Cruz, M.S.; Biritwum, N.-K.; Ofosu, A.; Gute, D.; Kosinski, K.C.; Naumova, E.N. The use of remotely sensed environmental parameters for spatial and temporal schistosomiasis prediction across climate zones in Ghana. Environ. Monit. Assess. 2019, 191, 301. [CrossRef]

334. King, C.H.; Bertsch, D. Historical Perspective: Snail Control to Prevent Schistosomiasis. PLoS Negl. Trop. Dis. 2015, 9, e0003657. [CrossRef]

335. King, C.; Sutherland, L.J.; Bertsch, D. Systematic Review and Meta-analysis of the Impact of Chemical-Based Mollusciciding for Control of Schistosoma mansoni and S. haematobium Transmission. PLoS Negl. Trop. Dis. 2015, 9, e0004290. [CrossRef]

336. King, C.H.; Sturrock, R.F.; Kariuki, H.C.; Hamburger, J. Transmission control for schistosomiasis-why it matters now. Trends Parasitol. 2006, 22, 575-582. [CrossRef]

337. Yang, G.-J.; Sun, L.-P.; Hong, Q.-B.; Zhu, H.-R.; Yang, K.; Gao, Q.; Zhou, X.-N. Optimizing molluscicide treatment strategies in different control stages of schistosomiasis in the People's Republic of China. Parasites Vectors 2012, 5, 260. [CrossRef]

338. Tanaka, H.; Tsuji, M. From discovery to eradication of schistosomiasis in Japan: 1847-1996. Int. J. Parasitol. 1997, 27, 1465-1480. [CrossRef]

339. WHO. Molluscicide screening and evaluation. Bull. World Health Organ. 1965, 33, 567-581.

340. Woolhouse, M.E.J.; Etard, J.-F.; Dietz, K.; Ndhlovu, P.D.; Chandiwana, S.K. Heterogeneities in schistosome transmission dynamics and control. Parasitology 1998, 117, 475-482. [CrossRef]

341. Zhou, X.N.; Bergquist, R.; Leonardo, L.; Yang, G.J.; Yang, K.; Sudomo, M.; Olveda, R. Schistosomiasis japonica control and research needs. Adv. Parasitol. 2010, 72, 145-178.

342. Minggang, C.; Zheng, F. Schistosomiasis control in China. Parasitol. Int. 1999, 48, 11-19. [CrossRef]

343. Knopp, S.; Ame, S.M.; Person, B.; Hattendorf, J.; Rabone, M.; Juma, S.; Muhsin, J.; Khamis, I.S.; Hollenberg, E.; Mohammed, K.A.; et al. A 5-Year intervention study on elimination of urogenital schistosomiasis in Zanzibar: Parasitological results of annual cross-sectional surveys. PLoS Negl. Trop. Dis. 2019, 13, e0007268. [CrossRef]

344. Lo, N.C.; Gurarie, D.; Yoon, N.; Coulibaly, J.T.; Bendavid, E.; Andrews, J.R.; King, C. Impact and cost-effectiveness of snail control to achieve disease control targets for schistosomiasis. Proc. Natl. Acad. Sci. 2018, 115, E584-E591. [CrossRef]

345. Person, B.; Ali, S.M.; A’Kadir, F.M.; Ali, J.N.; Mohammed, U.A.; Mohammed, K.A.; Rollinson, D.; Knopp, S. Community Knowledge, Perceptions, and Practices Associated with Urogenital Schistosomiasis among School-Aged Children in Zanzibar, United Republic of Tanzania. PLoS Negl. Trop. Dis. 2016, 10, e0004814. [CrossRef] [PubMed]

346. Stothard, R.; French, M.D.; Khamis, I.S.; Basáñez, M.-G.; Rollinson, D. The epidemiology and control of urinary schistosomiasis and soil-transmitted helminthiasis in schoolchildren on Unguja Island, Zanzibar. Trans. R. Soc. Trop. Med. Hyg. 2009, 103, 1031-1044. [CrossRef] [PubMed]

347. Stothard, J.R.; Mook, P.; Mgeni, A.F.; Khamis, I.S.; Khamis, A.N.; Rollinson, D. Control of urinary schistosomiasis on Zanzibar (Unguja Island): A pilot evaluation of the educational impact of the Juma na Kichocho health booklet within primary schools. Memórias Do Instituto Oswaldo Cruz 2006, 101, 119-124. [CrossRef]

348. Savioli, L.; Dixon, H.; Kisumku, U.M.; E Mott, K. Control of morbidity due to Schistosoma haematobium on Pemba Island: Programme organization and management. Trop. Med. Parasitol. Off. Organ Dtsch. Tropenmedizinische Ges. Dtsch. Ges. fur Tech. Zusammenarbeit (GTZ) 1989, 40, 189-194.

349. Ejike, C.U.; Oluwole, A.S.; Mogaji, H.O.; Adeniran, A.A.; Alabi, O.M.; Ekpo, U.F. Development and testing of Schisto and Ladders $^{\mathrm{TM}}$, an innovative health educational game for control of schistosomiasis in schoolchildren. BMC Res. Notes 2017, 10, 1-9. [CrossRef]

350. Adeneye, A.; Akinwale, O.; Idowu, E.; Adewale, B.; Manafa, O.; Sulyman, M.; Omotola, B.; Akande, D.; Mafe, M.; Appelt, B. Sociocultural aspects of mass delivery of praziquantel in schistosomiasis control: The Abeokuta experience. Res. Soc. Adm. Pharm. 2007, 3, 183-198. [CrossRef] [PubMed]

351. John, R.; Ezekiel, M.; Philbert, C.; Andrew, A. Schistosomiasis transmission at high altitude crater lakes in Western Uganda. BMC Infect. Dis. 2008, 8, 110. [CrossRef]

352. Hewlett, B.S.; Cline, B.L. Anthropological contributions to a community-based schistosomiasis control project in northern Cameroun. Trop. Med. Int. Health 1997, 2, 25-36.

353. Mangal, T.D.; Paterson, S.; Fenton, A. Predicting the Impact of Long-Term Temperature Changes on the Epidemiology and Control of Schistosomiasis: A Mechanistic Model. PLoS ONE 2008, 3, e1438. [CrossRef]

354. Stensgaard, A.-S.; Utzinger, J.; Vounatsou, P.; Hürlimann, E.; Schur, N.; Saarnak, C.F.L.; Simoonga, C.; Mubita, P.; Kabatereine, N.B.; Tchuenté, L.-A.T.; et al. Large-scale determinants of intestinal schistosomiasis and intermediate host snail distribution across Africa: Does climate matter? Acta Trop. 2013, 128, 378-390. [CrossRef]

355. Monde, C.; Syampungani, S.; Brink, P.J.V.D. Natural and human induced factors influencing the abundance of Schistosoma host snails in Zambia. Environ. Monit. Assess. 2016, 188, 370. [CrossRef] [PubMed]

356. McCreesh, N.; Nikulin, G.; Booth, M. Predicting the effects of climate change on Schistosoma mansoni transmission in eastern Africa. Parasites Vectors 2015, 8, 1-9. [CrossRef] [PubMed] 
357. McCreesh, N.; Arinaitwe, M.; Arineitwe, W.; Tukahebwa, E.M.; Booth, M. Effect of water temperature and population density on the population dynamics of Schistosoma mansoni intermediate host snails. Parasites Vectors 2014, 7, 503. [CrossRef] [PubMed]

358. McCreesh, N.; Booth, M. The Effect of Simulating Different Intermediate Host Snail Species on the Link between Water Temperature and Schistosomiasis Risk. PLoS ONE 2014, 9, e87892. [CrossRef]

359. Pedersen, U.B.; Karagiannis-Voules, D.-A.; Midzi, N.; Mduluza, T.; Mukaratirwa, S.; Fensholt, R.; Vennervald, B.J.; Kristensen, T.K.; Vounatsou, P.; Stensgaard, A.-S. Comparison of the spatial patterns of schistosomiasis in Zimbabwe at two points in time, spaced twenty-nine years apart: Is climate variability of importance? Geospat. Health 2017, 12, 505. [CrossRef]

360. Midzi, N.; Mtapuri-Zinyowera, S.; Mapingure, M.P.; Paul, N.H.; Sangweme, D.; Hlerema, G.; Mutsaka, M.J.; Tongogara, F.; Makware, G.; Chadukura, V.; et al. Knowledge attitudes and practices of grade three primary schoolchildren in relation to schistosomiasis, soil transmitted helminthiasis and malaria in Zimbabwe. BMC Infect. Dis. 2011, 11, 169. [CrossRef]

361. Mekonnen, A.; Legesse, M.; Belay, M.; Tadesse, K.; Torben, W.; Teklemariam, Z.; Erko, B. Efficacy of Praziquantel against Schistosoma haematobium in Dulshatalo village, western Ethiopia. BMC Res. Notes 2013, 6, 392. [CrossRef]

362. Kabatereine, N.B.; Brooker, S.; Tukahebwa, E.M.; Kazibwe, F.; Onapa, A.W. Epidemiology and geography of Schistosoma mansoni in Uganda: Implications for planning control. Trop. Med. Int. Heal. 2004, 9, 372-380. [CrossRef]

363. Olivier, T.J.; Handy, K.Q.; Bauer, R.T. Effects of river control structures on the juvenile migration ofMacrobrachium ohione. Freshw. Biol. 2013, 58, 1603-1613. [CrossRef]

364. Hunter, J.M. Parasitic Diseases in Water Resources Development: The Need for Intersectoral Negotiation; World Health Organization: Geneva, Swizterland, 1993.

365. Jobin, W.R. Dams and Disease: Ecological Design and Health Impacts of Large Dams, Canals, and Irrigation Systems; E \& FN Spon.: London, UK; New York, NY, USA, 1999.

366. Swartz, S.J.; De Leo, G.A.; Wood, C.L.; Sokolow, S.H. Infection with schistosome parasites in snails leads to increased predation by prawns: Implications for human schistosomiasis control. J. Exp. Biol. 2015, 218, 3962-3967. [CrossRef]

367. Sokolow, S.H.; Lafferty, K.D.; Kuris, A.M. Regulation of laboratory populations of snails (Biomphalaria and Bulinus spp.) by river prawns, Macrobrachium spp. (Decapoda, Palaemonidae): Implications for control of schistosomiasis. Acta Trop. 2014, 132, 64-74. [CrossRef]

368. Diakité, N.R.; Winkler, M.S.; Coulibaly, J.T.; Guindo-Coulibaly, N.; Utzinger, J.; N'Goran, E.K. Dynamics of freshwater snails and Schistosoma infection prevalence in schoolchildren during the construction and operation of a multipurpose dam in central Côte d'Ivoire. Infect. Dis. Poverty 2017, 6, 1-9. [CrossRef]

369. Martínez, B.B.; Talavera, J.R.; Robayna, A.A.; Valencia, A.C.; Morales, N.O.; García, L.G.; Pérez, M.S.C.; Pisaca, M.F.R. Parasitic Hematuria: Six Cases in a Row in a Single Centre in Spain. Urol. Int. 2017, 102, 360-363. [CrossRef]

370. Cetron, M.S.; Chitsulo, L.; Sullivan, J.J.; Pilcher, J.; Wilson, M.; Noh, J.; Tsang, V.C.; Hightower, A.W.; Addiss, D.G. Schistosomiasis in Lake Malawi. Lancet 1996, 348, 1274-1278. [CrossRef]

371. Visser, L.G.; Polderman, A.M.; Stuiver, P.C. Outbreak of Schistosomiasis Among Travelers Returning from Mali, West Africa. Clin. Infect. Dis. 1995, 20, 280-285. [CrossRef]

372. Zuidema, P.J. The Katayama syndrome; an outbreak in Dutch tourists to the Omo National Park, Ethiopia. Trop. Geogr. Med. 1981, $33,30-35$.

373. Istre, G.R.; Fontaine, R.E.; Tarr, J.; Hopkins, R.S. Acute Schistosomiasis Among Americans Rafting the Omo River, Ethiopia. JAMA 1984, 251, 508-510. [CrossRef]

374. Elcuaz, R.; Armas, M.; Ramírez, M.; Noguera, F.J.; Bolaños, M.; Quiñones, I.; Lafarga, B. Outbreak of schistosomiasis in a group a travellers returning from Burkina Faso. Enferm. Infecc. Microbiol. Clin. 1998, 16, 367-369.

375. Luque, A.; Díaz, L.; Martos, S.; Sánchez, L.; Fernández, A.; Chamorro, M. Imported diseases in Spain: Difficulties in health care. Enfermería Global 2019, 18, 595-607.

376. Berry, A.; Moné, H.; Iriart, X.; Mouahid, G.; Abbo, O.; Boissier, J.; Fillaux, J.; Cassaing, S.; Debuisson, C.; Valentin, A.; et al. Schistosomiasis Haematobium, Corsica, France. Emerg. Infect. Dis. 2014, 20, 1595-1597. [CrossRef]

377. Holtfreter, M.C.; Moné, H.; Müller-Stöver, I.; Mouahid, G.; Richter, J. Schistosoma haematobium infections acquired in Corsica, France, August 2013. Eurosurveillance 2014, 19, 20821. [CrossRef]

378. Calvo-Cano, A.; Cnops, L.; Huyse, T.; Van Lieshout, L.; Pardos, J.; Valls, M.E.; Franco, A.; Rollinson, D.; Gascon, J. A Case of Urogenital Human Schistosomiasis from a Non-endemic Area. PLoS Negl. Trop. Dis. 2015, 9, e0004053. [CrossRef] [PubMed]

379. Roure, S.; Valerio, L.; Pérez-Quílez, O.; Fernández-Rivas, G.; Martínez-Cuevas, O.; Alcántara-Román, A.; Viasus, D.; Pedro-Botet, M.L.; Sabrià, M.; Clotet, B. Epidemiological, clinical, diagnostic and economic features of an immigrant population of chronic schistosomiasis sufferers with long-term residence in a non-endemic country (North Metropolitan area of Barcelona, 2002-2016). PLoS ONE 2017, 12, e0185245. [CrossRef]

380. WHO. COID-19: WHO Issues Interim Guidance for Implementation of NTD Programmes. Available online: https://www. who.int/neglected_diseases/news/COVID19-WHO-interim-guidance-implementation-NTD-programmes/en/ (accessed on 7 September 2020).

381. Mackee, N. COVID Fears Drive Patients to Avoid Doctors, Hospitals. Available online: https://insightplus.mja.com.au/2020/1 7/ covid-19-avoiding-doctors-clinicians-brace-for-wave-of-severe-illnesses / (accessed on 7 September 2020).

382. Solomon, M.D.; McNulty, E.J.; Rana, J.S.; Leong, T.K.; Lee, C.; Sung, S.-H.; Ambrosy, A.P.; Sidney, S.; Go, A.S. The Covid-19 Pandemic and the Incidence of Acute Myocardial Infarction. N. Engl. J. Med. 2020, 383, 691-693. [CrossRef] 
383. Hafner, K. Fear of Covid-19 Leads Other Patients to Decline Critical Treatment, in New York Times; PPSNet: New York, NY, USA, 2020.

384. Siripanthong, B.; Hanff, T.C.; Levin, M.G.; Vidula, M.K.; Khanji, M.Y.; Nazarian, S.; A Chahal, C.A. Coronavirus disease 2019 is delaying the diagnosis and management of chest pain, acute coronary syndromes, myocarditis and heart failure. Futur. Cardiol. 2021, 17, 3-6. [CrossRef]

385. Oyeyemi, O.T.; Okunlola, O.A.; Adebayo, A.D. Assessment of schistosomiasis endemicity and preventive treatment on coronavirus disease 2019 outcomes in Africa. New Microbes New Infect. 2020, 38, 100821. [CrossRef]

386. Kayuni, S.A.; O’Ferrall, A.M.; Baxter, H.; Hesketh, J.; Mainga, B.; Lally, D.; Al-Harbi, M.H.; LaCourse, E.J.; Juziwelo, L.; Musaya, J.; et al. An outbreak of intestinal schistosomiasis, alongside increasing urogenital schistosomiasis prevalence, in primary school children on the shoreline of Lake Malawi, Mangochi District, Malawi. Infect. Dis. Poverty 2020, 9, 1-10. [CrossRef] [PubMed]

387. Hillyer, J.F. Parasites and Parasitology in this SARS-CoV-2, COVID-19 World: An American Society of Parasitologists Presidential Address. J. Parasitol. 2020, 106, 859-868. [CrossRef] [PubMed]

388. Gutman, J.R.; Lucchi, N.W.; Cantey, P.T.; Steinhardt, L.C.; Samuels, A.M.; Kamb, M.L.; Kapella, B.K.; McElroy, P.D.; Udhayakumar, V.; Lindblade, K.A. Malaria and Parasitic Neglected Tropical Diseases: Potential Syndemics with COVID-19? Am. J. Trop. Med. Hyg. 2020, 103, 572-577. [CrossRef] [PubMed]

389. King, C.H.; Dickman, K.; Tisch, D.J. Reassessment of the cost of chronic helmintic infection: A meta-analysis of disability-related outcomes in endemic schistosomiasis. Lancet 2005, 365, 1561-1569. [CrossRef] 